\title{
INSTITUTO DE FÍSICA DE SÃO CARLOS
}

\section{SILVIA CALBO AROCA}

Ensino de física solar em um espaço não formal de educação

São Carlos

2008 



\section{SILVIA CALBO AROCA}

\section{Ensino de física solar em um espaço não formal de educação}

Tese apresentada ao Programa de Pós-Graduação do Instituto de Fisica de São Carlos da

Universidade de São Paulo para obtenção do título de Doutor em ciências.

Área de Concentração: Física Básica

Orientador: Prof. Dra. Cibelle Celestino Silva

São Carlos

2008 
AUTORIZO A REPRODUÇÃO E DIVULGAÇÃO TOTAL OU PARCIAL DESTE TRABALHO, POR QUALQUER MEIO CONVENCIONAL OU ELETRÔNICO, PARA FINS DE ESTUDO E PESQUISA, DESDE QUE CITADA A FONTE.

Ficha catalográfica elaborada pelo Serviço de Biblioteca e Informação IFSC/USP

Aroca, Silvia Calbo.

Ensino de física solar em um espaço não formal de educação Silvia Calbo Aroca; orientadora Cibelle Celestino Silva.-- São Carlos, 2008. $173 \mathrm{p}$.

Tese (Doutorado em Ciências - Área de concentração: Física Básica ) Instituto de Física de São Carlos da Universidade de São Paulo.

1. Museus de ciências. 2. Sol. 3. Educação não formal. 4. Ensino de astronomia. 5. Espectro solar. I. Título. 


\section{FOLHA DE APROVAÇÃO}

Silvia Calbo Aroca

Tese apresentada ao Instituto de Fisica de São

Carlos da Universidade de São Paulo para obtenção do título de Doutor em Ciências. Área de Concentração: Fisica Básica.

Aprovada em: 13/02/2009

\section{Comissão Julgadora}

Profa. Dra. Cibelle celestino Silva

Instituição: IFSC/USP

Assinatura

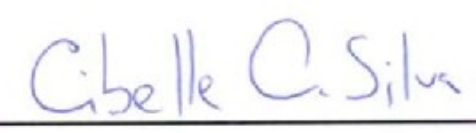

Prof. Dr. Roberto Boczko

Instituiçăo: IAG/USP

Prof. Dr. Sérgio Mascarello Bisch InstituiçãoUFES

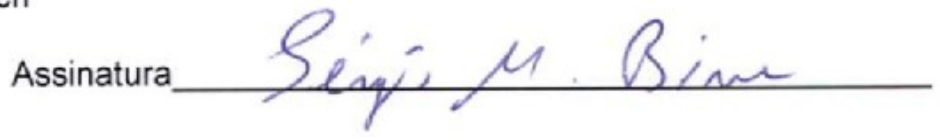

Prof. Dr. Wilton da Silva Dias

Instituiçăo: UNIFEI

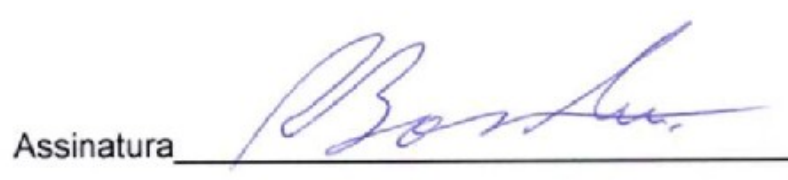





\section{Agradecimentos}

Aos meus pais por sempre terem, em todas as etapas, confiado e me apoiado.

Ao meu querido marido Rafael, pela compreensão e infindável colaboração ao longo deste trabalho e ao pequeno Matheus que me trouxe muita alegria.

Ao Jorge do Observatório pelo valioso apoio técnico, sem o qual este trabalho de pesquisa não poderia ter sido realizado.

À orientadora Cibelle por quem tenho grande admiração pela orientação, incentivo e amizade.

Ao professor Schiel pela co-orientação.

Aos integrantes do grupo de pesquisa Pedro, Anita, Aldo e Nilva pelas dicas, compa-

nheirismo e artigos trocados durante a execução deste projeto. À equipe do Observatório pela convivência, dicas e sugestões.

Aos alunos que participaram dos minicursos, que tornaram este trabalho possível.

A Rogério Marcon da Rede de Astronomia Observacional pelo apoio técnico de alto nível e valiosas sugestões.

Ao CNPq e Fundação Vitae pelo apoio financeiro.

À Dario Pires, pelas dicas de instrumentação e confecção de equipamentos para esta pesquisa.

Ao professor Aprígio e à equipe do CDCC pelo apoio financeiro, instrumental e computacional.

Ao Wilton Dias, pelo incentivo em desenvolver um projeto de ensino de Astronomia no IFSC.

À Oficina de óptica do IFSC pela confecção dos espelhos do heliostato.

À professora Martha Marandino por ministrar a disciplina Educação não formal e divulgação científica que foi fundamental para desenvolver o referencial teórico deste trabalho.

Ao Ednilson Oliveira por ensinar as técnicas de observação solar e por demonstrar tanta paixão e dedicação à Astronomia brasileira.

Ao Clube de Astronomia de Brasilia, pelo carinho e incentivo. 
Ao Antônio Carlos do CDCC pela participação e ajuda durante os minicursos.

Ao Hércio do Laboratório de Ensino do IFSC pelo empréstimo de equipamentos. Ao Carlos Colesanti, Tasso Napoleão e à REA pelo empréstimo de equipamentos e pelo incentivo em divulgar Astronomia. 


\section{Resumo}

AROCA S. C. Ensino de física solar em um espaço não formal de educação. 2008. Tese (Doutorado) - Instituto de Física de São Carlos, Universidade de São Paulo, São Carlos, 2009.

Planetários e observatórios oferecem a possibilidade de desenvolver um ensino contextualizado de Astronomia, permitindo a realização de atividades educativas que proporcionam acesso a uma ciência escolar mais autêntica. Com isso em vista, esta pesquisa consistiu no desenvolvimento, aplicação e análise de minicursos sobre o Sol, para o ensino fundamental e física solar, para o ensino médio em um espaço não formal de educação, o Observatório Astronômico do CDCC/USP. Tópicos como a composição química, temperatura e evolução estelar foram ensinados a partir de experimentos clássicos em uma sala totalmente dedicada ao Sol, a Sala Solar com equipamentos de baixo custo. Os cursos enfatizaram atividades práticas, observacionais e questionadoras, como discussões sobre a natureza do Sol, manchas solares e proeminências, estimativas da temperatura da fotosfera, observação do espectro solar na região do visível e identificação das linhas de absorção entendendo como são produzidas e que tipo de informações podem ser extraídas a partir delas. O objetivo do curso do ensino fundamental foi mostrar que o Sol é um astro dinâmico e que influencia a Terra de diversas maneiras, além de contextualizar o conteúdo ensinado com atividades práticas. O objetivo do curso do ensino médio foi compreender o papel chave desempenhado pela espectroscopia na astrofísica e permitir abordagens interdisciplinares incluindo física moderna e química no ensino de Astronomia. A metodologia de pesquisa consistiu de uma abordagem qualitativa com a realização de questionários escritos, entrevistas semi-estruturadas e filmagens. Antes dos cursos, muitos alunos concebiam o Sol como sendo uma esfera quente de fogo, as manchas solares como sendo buracos no Sol e as proeminências como magma expelido por vulcões. Após a realização dos cursos os alunos apresentaram ideias sobre o Sol e aspectos de física solar mais próximas das aceitas hoje em dia pela comunidade científica. Esta pesquisa não ficou restrita aos ganhos cognitivos dos alunos após a realização dos minicursos, pois considerou a interação de diferentes contextos responsáveis pela aprendizagem em museus de ciências. Isso foi possível pelo referencial teórico adotado: o Modelo Contextual de Aprendizagem de Falk e Dierking. Trabalhar conteúdos astronômicos de forma interdisciplinar e ao mesmo tempo de maneira ativa e questionadora traz alguns desafios para as equipes de instituições como o Observatório. As atividades elaboradas nos centros de ciências devem ter como principal objetivo despertar o interesse do aprendiz pela ciência, mas também destacamos a necessidade da oferta de minicursos para voluntários, pois a linguagem, conteúdos e metodologias em atividades mais longas podem facilitar abordagens interdisciplinares e integradoras da Astronomia com outras áreas do conhecimento científico pouco exploradas nas salas de aula. Isso pode ocorrer quando o projeto pedagógico da escola é construído coletivamente, envolvendo museus de ciências, professores, escola e alunos buscando conciliar propostas de um ensino de ciências que considere o contexto fora da escola e que ao mesmo tempo tenha relação com o que o aluno está estudando em sala de aula.

Palavras-chave: museus de ciências, Sol, educação não formal, ensino de astronomia, espectro solar 



\section{Abstract}

AROCA S. C. Teaching solar physics in an informal educational space. 2008. Thesis (Doctorate) - Instituto de Física de São Carlos, Universidade de São Paulo, São Carlos, 2009.

Observatories and planetariums offer the possibility of developing contextualized astronomy teaching by fostering educational activities that provide access to a more authentic school science. Thus, this research consisted in developing, applying and evaluating courses about the Sun for middle, junior high school students and solar physics for high school students in an informal educational space, the CDCC/USP Astronomical Observatory. Topics of chemical composition, temperature and stellar evolution were taught in a room totally dedicated to the study of the Sun, a Solar Room, designed with simple and inexpensive equipment. The course strongly emphasized practical, observational and inquirybased activities, such as estimation of the solar surface temperature, observation of the visible solar spectrum, identification of solar absorption lines, understanding how they are produced, and what kind of information can be extracted from the observed spectral lines. Some of the course goals were to foster the comprehension of the key role played by spectroscopy in astrophysics, to contextualize contents with practical activities, and to allow interdisciplinary approaches including modern physics and chemistry in physics teaching. The research methodology consisted of a qualitative approach by filming the whole course and performing written questionnaires and semi-structured interviews. Before the courses were applied most students conceived the Sun as a hot sphere composed of fire, sunspots as holes in the Sun and solar prominences as magma expelled by volcanoes. After the courses students presented ideas about the Sun and solar physics more closely related to the ones accepted by contemporary science. This research was not restricted to students' cognitive gains after concluding the courses, since it considered the interaction of different contexts responsible for learning in science museums. This was possible due to the theoretical framework adopted: The Contextual Model of Learning of Falk and Dierking. Some challenges have to be faced by institutions such as the Astronomical Observatory in order to teach astronomy in an interdisciplinary form and with inquiry-based activities The activities developed at science centers must have as their main objective to motivate the public towards science, but it is also important to offer courses for volunteers, since language, contents and methodologies in longer activities can facilitate interdisciplinary approaches of Astronomy with other areas of scientific knowledge seldom explored in classrooms. This can happen when the school's educational project is collectively constructed including science museums, teachers, school and students by seeking to enhance teaching proposals that consider the out of school context and is related to contents taught in the classroom.

Keywords: science centers, Sun, informal education, astronomy teaching, solar spectrum 



\section{Lista de Figuras}

Figura 1 - Modelo da experiência interativa de aprendizagem (FALK; DIERKING, 1992) . 50

Figura 2 - Observatório Astronômico do CDCC/USP no Campus I de São Carlos . . . . 54

Figura 3 - O refrator Grubb. . . . . . . . . . . . . . . . . 55

Figura 4 - Funcionamento da sala solar. Na Fig. 1 temos o esquema da parte de cima da sala solar mostrando a trajetória de raios de luz do Sol que atingem primeiro o espelho plano móvel, que direciona a luz para o espelho plano fixo, que por sua vez, atinge o telescópio que encontra-se na vertical. Na Fig. 2 temos um desenho da parte de dentro e de cima da sala solar mostrando o heliostato (jogo de 2 espelhos planos) e o Sol sendo projetado pelo telescópio. Por fim na Fig. 3 temos o desenho do interior da sala solar onde existem muitas pessoas observando a imagem de manchas solares no disco projetado na parede. Fonte: Fundação Planetário do Rio de Janeiro . . . . . . . . . . 58

Figura 5 - Na figura da esquerda temos um esquema mostrando o funcionamento do heliostato, onde a letra A indica o espelho móvel, a letra B o espelho fixo e a letra $\mathrm{C}$ o tubo do telescópio que se situa no interior da sala solar. Na figura da direita temos uma imagem do Heliostato do Observatório do CDCC/USP. 58

Figura 6 - Método de projeção solar e gabarito de observação solar. Figura do European Southern Observatories (ESO). . . . . . . . . . . . . . . . 59

Figura 7 - O telescópio PST da CORONADO que possui um filtro hidrogênio-alfa . . . 60

Figura 8 - O telescópio PST da CORONADO acoplado ao refrator Grubb . . . . . . . . 61

Figura 9 - Esquema do funcionamento do espectroscópio Littrow. A luz entra pelo telescópio A passa pela fenda B, que atravessa então uma lente colimadora $\mathrm{C}$ que direciona o feixe incidente em uma rede de difração por reflexão $\mathrm{D}$, que reflete o espectro solar em um anteparo na altura da fenda E. . . . . . . . .

Figura 10 - Imagem do espectroscópio Littrow da sala solar. A luz entra pelo telescópio A passa pela fenda B, que atravessa então uma lente colimadora $\mathrm{C}$, que direciona o feixe incidente em uma rede de difração por reflexão $\mathrm{D}$, que reflete o espectro solar em um anteparo na altura da fenda. E. . . . . . . . . . . . . . . 
Figura 11 - Representação de um campo de futebol com o Sistema Solar disposto em escala de distância. Crédito: Costa $(2006)$. . . . . . . . . . . . . 71

Figura 12 - Representação solar de um aluno de quinta série. . . . . . . . . . . . . . . . 81

Figura 13 - Representação solar de um aluno de quinta série. . . . . . . . . . . . . . . . 82

Figura 14 - Representação do Sol de um aluno de sétima série. . . . . . . . . . . . . . 83

Figura 15 - Representação do Sol de um aluno de oitava série. . . . . . . . . . . . . . . 84

Figura 16 - Representação de proeminências solares observadas pelo telescópio por uma aluna de sexta série. . . . . . . . . . . . . . . . . . . . . . . 91

Figura 17 - Classificação de proeminências solares (ZIRIN, 1988) . . . . . . . . . . . . . 92

Figura 18 - Imagem de dentro do livro premiado de uma aluna da sexta série. . . . . . . 95

Figura 19 - Capa do livro de uma aluna de oitava série. . . . . . . . . . . . . . 95

Figura 20 - Desenho de dentro do livro de uma aluna de oitava série mostrando o método de projeção solar usado durante o mini-curs o. . . . . . . . . . . . . . . . . 95

Figura 21 - Configuração do sistema Sol-Terra-Lua usado por Aristarco de Samos para estimar a distância da Terra ao Sol. . . . . . . . . . . . . . . . . . . . 102

Figura 22 - Atividade para se estimar o diâmetro do Sol. Fonte da imagem: http:// vts.bc.ca/pgrasc/Student_Handouts/solar_distance.html . . . . . 104

Figura 23 - Posição da lata exposta ao Sol. É importante certificar-se de que a lata projete uma sombra retangular para permitir que os raios de luz atinjam sua superfície. Fonte: http://educar.sc.usp.br/experimentoteca/fisica/ kit3_calorimetria/exp6_termo.pdf . . . . . . . . . . . . 112

Figura 24 - Área longitudinal da lata, (dxh). Fonte: http://educar.sc.usp.br/experimentoteca/ fisica/kit3_calorimetria/exp6_termo.pdf . . . . . . . . . . 113

Figura 25 - Desenho da aluna J. do primeiro ano representando os espectros das lâmpadas incandescente e fluorescente observadas durante o curso.

Figura 26 - Desenho da aluna J. do primeiro ano mostrando o espectro de uma lâmpada de mercúrio e de hélio observadas no curso. . . . . . . . . . . . . . . . 123

Figura 27 - Espectro solar obtido no Observatório Astronômico do CDCC/USP mostrando algumas linhas espectrais de Fraunhofer. 
Figura 28 - Ilustração do experimento da descoberta do infravermelho de Herschel. .. . 125

Figura 29 - Estrutura do Sol (COSTA; CALBO; OLIVEIRA, 1995) . . . . . . . . . . . . 150

Figura 30 - Imagem mostrando o detalhe de uma mancha solar, umbra e penumbra. Fonte: NASA $/$ GSFC . . . . . . . . . . . . . . . . . . . 151

Figura 31 - Cromosfera solar visível durante o eclipse solar total de 2002. Fonte da figura: NASA/Steele Hill/Arne Danielsen . . . . . . . . . . . . . . . . . 152

Figura 32 - Imagem da cromosfera mostrando espículas. Fonte: NASA/ Marshall Space Flight Center . . . . . . . . . . . . . . . . 153

Figura 33 - Imagem de um flare fotografado em ultravioleta extremo em 1973. Fonte: NASA . . . . . . . . . . . . . . . . . . 153

Figura 34 - Coroa solar visível durante o eclipse solar total de 1991. Fonte da figura: High Altitude Observatory at Mauna Kea no Havaí . . . . . . . . . . . . . 154

Figura 35 - Imagem mostrando a ejeção de massa coronal. Fonte: High Altitude Observatory . . . . . . . . . . . . . . . . . . . 154

Figura 36 - Espectro solar mostrando as linhas de Fraunhofer. Fonte NASA . . . . . . . 155

Figura 37 - Ilustração mostrando as leis de Kirchoff. Fonte: NASA . . . . . . . . . . . . 157

Figura 38 - Desenhos feito por Galileo em 1610 mostrando as manchas solares. Figura da obra: Istoria e Dimostrazioni Intorno Alle Macchie Solari e Loro Accidenti Rome de Galileo Galilei (GALILEI, 1613). . . . . . . . . . . . . . . . . 159

Figura 39 - Distorção das linhas do campo magnético causadas pela rotação diferencial do Sol (COSTA; CALBO; OLIVEIRA, 1995). . . . . . . . . . . . 160

Figura 40 - Gráfico do número de Wolf em função do ano, mostrando vários ciclos solares (subida e descida nas curvas). Fonte: NASA/Marshall Space Flight Center. . 161

Figura 41 - Observação solar ilustrando a contagem do número de Wolf. Fonte da figura: COSTA; CALBO; OLIVEIRA (1995). . . . . . . . . . . . . 162

Figura 42 - Classificação de manchas solares (COSTA; CALBO; OLIVEIRA, 1995) . . 163

Figura 43 - Imagem do Sol pela sonda Hinode no ultravioleta extremo mostrando um flare. Fonte: NASA/MSFC . . . . . . . . . . . . . . . . . . 164 
Figura 44 - Heliostato para uso em escolas. A luz solar incide primeiramente no espelho móvel (1), em seguida é direcionada ao espelho fixo (2) que a direciona para o telescópio (3) que projeta a imagem do Sol em sua outra extremidade. . . . 167 


\section{Lista de Tabelas}

Tabela 1 - Relação de alunos dos minicursos de 2006 e 2007, respectivamente. . . . . . . 65

Tabela 2 - Principais linhas de absorção do espectro solar no visível. As bandas A, B e a pertencem à nossa atmosfera. . . . . . . . . . . . . . 156 


\section{Sumário}

1 Introdução

2 Pesquisas sobre ensino de Astronomia 25

2.1 Pesquisas de educação em Astronomia para o ensino fundamental . . . . . . . 26

2.2 Pesquisas de educação em Astronomia para o ensino médio e superior . . . . . 29

2.3 Pesquisa sobre ensino de Astronomia em espaços não formais de educação . 31

3 Educação em museus de ciências $\quad 34$

3.1 Um pouco da história de museus de ciências no Brasil . . . . . . . . . . . . . . 34

3.2 Educação em museus de ciências . . . . . . . . . . . . . . . . . . . . . 36

3.3 Museus de ciências na contextualização do currículo escolar . . . . . . . . . . . 41

3.3.1 A importância da parceria museu de ciências e escola . . . . . . . . . . . . . 44

3.3.2 Maximizando o potencial educativo de visitas escolares aos museus de ciências 45

3.4 Referenciais teóricos de aprendizagem em museus de ciências adotados neste

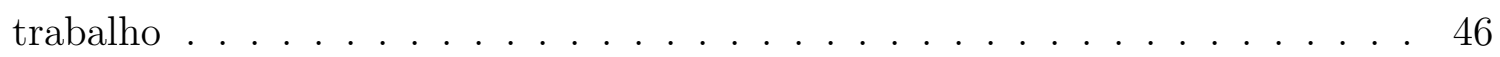

3.4.1 O modelo contextual de aprendizagem . . . . . . . . . . . . . 50

4 O Observatório Astronômico do CDCC/USP $\quad 54$

4.1 Instalações . . . . . . . . . . . . . . . . . . . . . . 54

4.2 Atividades educativas . . . . . . . . . . . . . . . . . . . 56

4.3 A construção da sala solar e seus equipamentos . . . . . . . . . . . . . 57

5 Física solar para o ensino fundamental $\quad 63$

5.1 O contexto da proposta . . . . . . . . . . . . . 63

5.2 Os minicursos . . . . . . . . . . . . . . . . . . . . . 64

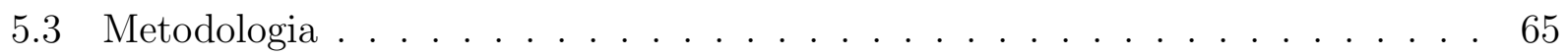

5.4 Discussão dos resultados . . . . . . . . . . . . . . . . . . . . . . . . . . 69

5.4 .1 O Sol: seu tamanho e distância à Terra . . . . . . . . . . . . . . . . . 69

5.4 Telescópios e cuidados ao se observar o Sol . . . . . . . . . . . . 74 
5.4.3 A constituição do Sol . . . . . . . . . . . . . . . . . . . . . . . . . . 79

5.4.4 Representações do Sol . . . . . . . . . . . . . . . . . . . . 80

5.4.5 Observação e natureza das manchas solares . . . . . . . . . . . . . . . 85

5.4.6 Observação de proeminências e a relação Sol-Terra . . . . . . . . . . . . . . 91

5.4 .7 Alguns comentários . . . . . . . . . . . . . . . . . . . . 94

6 Física solar para o ensino médio $\quad 97$

6.1 O contexto da proposta . . . . . . . . . . . . . . . 97

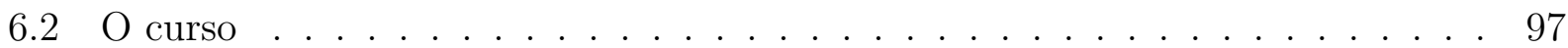

6.3 Metodologia . . . . . . . . . . . . . . . . . . . . 98

6.4 Discussão dos resultados . . . . . . . . . . . . . . . . . . . . . . 100

6.4.1 Estimativa geométrica da distância da Terra ao Sol e seu tamanho relativo . 101

6.4.2 Concepções sobre a natureza do Sol, manchas solares e proeminências . 105

6.4.3 Estimativa da temperatura na fotosfera solar . . . . . . . . . . . . . 111

6.4.4 Produção de energia solar . . . . . . . . . . . . . . . . . . 114

6.4.5 Observação do espectro solar no visível . . . . . . . . . . . . . . . . . . . . 117

6.4.6 Alguns Comentários . . . . . . . . . . . . . . . . . . . 130

7 Considerações finais $\quad 133$

$\begin{array}{ll}\text { Referências } & 141\end{array}$

APÊNDICE A - Alguns aspectos de física solar adequados ao ensino 146

A.1 Produção de energia solar . . . . . . . . . . . . . . . . . . . 146

A.2 Estrutura solar . . . . . . . . . . . . . . . . . . . . . . . 149

A.2.1 Do interior para a fotosfera . . . . . . . . . . . . . . . . 149

A.2.2 Fotosfera solar . . . . . . . . . . . . . . . . . . . . . 150

A.2.3 Cromosfera Solar . . . . . . . . . . . . . . . . . . . . . 151

A.2.4 Coroa solar . . . . . . . . . . . . . . . . . . . . . . . . 153

A.3 Espectro solar . . . . . . . . . . . . . . . . . . . . . . . . . . 154

A.4 Atividade solar . . . . . . . . . . . . . . . . . . . . . . 158 
A.4.1 Manchas solares e ciclo solar . . . . . . . . . . . . . . . . . . . 160

A.4.2 Relações Terra-Sol . . . . . . . . . . . . . . . . . . . . 164

APÊNDICE B - Heliostato para uso em escolas $\quad 167$

APÊNDICE C - Questionários para o ensino fundamental 169

APÊNDICE D - Questionários para o ensino médio 171

APÊNDICE E - Questionário de opinião sobre os cursos 173 


\section{Introdução}

O trabalho apresentado nesta pesquisa é decorrente de mais de dezesseis anos de envolvimento da autora com Astronomia e o ensino da Astronomia, sendo que o primeiro contato ocorreu em 1992 ao participar de cursos e palestras de Astronomia oferecidos no Observatório Astronômico do CDCC/USP quando cursava o ensino fundamental. Tal envolvimento com o Observatório e a constante busca em aprender mais sobre o tema, desencadearam, durante o ensino médio, no desenvolvimento de um projeto de pesquisa sobre manchas solares com uma colega e sob orientação de Ednilson Oliveira que trabalhava no Observatório do CDCC/USP (COSTA; CALBO; OLIVEIRA, 1995). Desde então, o Sol tem sido para mim algo fascinante de ser observado e estudado. Surge nesta época também a vontade de construir um equipamento que permitisse observar as linhas espectrais do Sol, o espectroscópio, a principal ferramenta da Astronomia contemporânea.

Minha primeira participação efetiva como divulgadora de Astronomia foi através do CAsB (Clube de Astronomia de Brasília) em 1996. Este Clube de Astronomia, assim como o Observatório do CDCC/USP, está preocupado em ensinar conteúdos de Astronomia para professores, alunos e para a comunidade por meio de cursos, palestras e observações astronômicas dentro e fora da cidade. Com isto, foi possível conhecer um pouco das dificuldades em ensinar Astronomia, proferir palestras e explicar o que estava sendo observado através de telescópios para um público tão amplo. Conteúdos de Astronomia, que para mim pareciam fáceis de compreender, para o público eram algo abstrato, distante e com pouco significado. Mas, ao mesmo tempo notava como os conteúdos de Astronomia eram interessantes para algumas pessoas e começava a perceber como é sensacional ensinar Astronomia.

Retornei a São Carlos com a intenção de estudar e divulgar Astronomia no Observatório Astronômico do CDCC/USP enquanto cursava Física no Instituto de Física de São Carlos. Durante este período começaram a sugir preocupações e questionamentos a respeito dos objetivos, resultados, limites, relevância dos conteúdos ensinados para a comunidade e os efeitos produzidos nas pessoas quando ensinávamos temas de Astronomia. 
Conclui a graduação com todas estas preocupações além da vontade de aprender mais sobre Astronomia, em especial astrofísica.

Isto me levou à obtenção do título de mestre em Astronomia pelo Instituto Astronômico, Geofísico e de Ciências Atmosféricas (IAG/USP). Durante o mestrado minhas necessidades não foram totalmente satisfeitas, pois sentia muita falta de ensinar e divulgar Astronomia. Foi com esta ausência que descobri que o caminho seguinte que deveria trilhar seria a pesquisa em ensino de Astronomia em espaços não formais.

Os próprios PCN (Parâmetros Curriculares Nacionais) salientam a necessidade de "atividades práticas, e visitas preparadas a observatórios, planetários, associações de astrônomos amadores, museus de Astronomia e de Astronáutica" (BRASIL, 1998). Mas, esses espaços não devem ser encarados apenas como oportunidades de atividades educativas complementares ou de lazer, mas sim fazer parte do processo de ensino/aprendizagem de forma planejada, sistemática e articulada (LANGHI, 2004). Nossa proposta de pesquisa e atividades considerou estas necessidades, uma vez que a desenvolvemos na forma de cursos dentro do Observatório Astronômico do CDCC/USP.

Há poucos trabalhos sobre o ensino de astronomia em espaços não formais no âmbito nacional e internacional. A maior parte dos artigos existentes são relativos às concepções de alunos e professores do ensino fundamental a respeito das fases da Lua, eclipses, estações do ano e da sucessão do dia e noite (conforme o capítulo 2). De uma maneira geral há pouquíssimos trabalhos que exploram o ensino de outros temas da Astronomia e de astrofísica. Assim, devido ao meu grande interesse pelo Observatório Astronômico do CDCC/USP e o Sol resolvi investigar o ensino de conceitos sobre o Sol e física solar para alunos de educação básica.

O Sol é um tema pouco conhecido pelos professores e alunos das escolas que nos procuram (acreditamos que esta seja uma realidade também presente no restante do país). Além disso, ao explorar conceitos sobre o Sol e de física solar penetramos em outros campos da ciência como a Física e a Química e desta forma promovemos um ensino interdisciplinar, que ajuda a superar a visão fragmentada de ciências que predomina nas escolas brasileiras.

Investigar as melhores maneiras de se ensinar Astronomia em espaços não formais, 
especialmente astrofísica, é altamente relevante no cenário atual do ensino de ciências da natureza, uma vez que a literatura é carente neste tema, apesar de diretrizes curriculares de vários países incluírem o ensino de Astronomia e promoverem parcerias com museus e centros de ciências. Atendendo a estes requisitos elaboramos uma pesquisa aqui relatada que buscou responder às seguintes questões:

- Como os alunos do ensino fundamental e médio concebem o Sol ?

- Como implementar atividades interdisciplinares para o ensino de física moderna em um espaço não formal?

- Que conjunto de atividades seria ideal para a construção de uma visão mais adequada sobre o Sol e física solar em um espaço não formal de educação?

- Quais são as estratégias metodológicas mais adequadas a serem adotadas ?

Para responder às questões da pesquisa elaboramos uma proposta de ensino na qual o próprio aluno é autor de seu conhecimento, uma vez que foi motivado a pensar no que estava sendo discutido durante e após a realização de pequenos experimentos, com seus colegas e a professora. O foco de estudo foram os alunos de quinta à oitava série do ensino fundamental e alunos do ensino médio.As questões de pesquisa estão respondidadas ao longo dos capítulos 5 e 6 bem como de maneira mais direta nas considerações finais.

No capítulo seguinte levantamos um panorama geral de pesquisas sobre ensino de Astronomia a fim de situarmos este trabalho. No terceiro capítulo são discutidos os principais referenciais teóricos de museus de ciências que foram adotados nesta pesquisa. Uma vez, que é necessário um olhar diferenciado para a educação que ocorre em museus de ciências em relação à educação que ocorre em sala de aula. Já no quarto capítulo, descrevemos as principais atividades do Observatório Astronômico do CDCC/USP e a concepção da sala solar e seus instrumentos. Nos dois capítulos seguintes apresentamos e discutimos os principais resultados e metodologias adotados na pesquisa com os alunos do ensino fundamental e médio, respectivamente. Por fim, apresentamos as conclusões e apêndices contendo alguns aspectos teóricos de física solar relevantes para alunos da rede 
de ensino, concepção de um heliostato para uso em escolas e os questionários escritos que foram aplicados nos minicursos do ensino fundamental e médio. 


\section{Pesquisas sobre ensino de Astronomia}

A maior parte dos trabalhos publicados sobre ensino de Astronomia encontram-se espalhados em revistas e jornais de ensino de ciências, psicologia cognitiva, ensino de física e revistas de divulgação de Astronomia. Existem poucos periódicos devotados exclusivamente ao ensino deste tema. Podemos citar apenas dois, a Revista Latino-Americana de Educação em Astronomia (RELEA) e a Astronomy Education Review.

Uma importante iniciativa em criar uma base de dados contendo referências de ensino de Astronomia foi desenvolvida por voluntários americanos da "American Astronomical Society Working Group on Astronomy Education" criada por Gina Brissenden (2002).Este grupo possui um "site" mantido por Dave Bruning contendo o título, autor, nome da revista e resumo dos trabalhos encontrados em 35 periódicos contendo artigos de ensino de Astronomia desde 1970. Neste capítulo iremos discutir alguns trabalhos desta base de dados e outros não citados na mesma, que julgamos relevantes para nossa pesquisa.

Conforme mencionado na Introdução, os trabalhos de pesquisa em ensino de Astronomia na literatura, na maior parte dos casos, envolvem temas como concepções de crianças e adolescentes sobre a Terra, estações do ano, fases da Lua, sucessão do dia e noite havendo poucos trabalhos sobre ensino de astrofísica. Este último tema, apesar de pouco explorado é muito importante, sobretudo para os alunos compreenderem o que é o Sol, e as demais estrelas e que as mesmas leis físicas são válidas na Terra e nos demais corpos celestes.

Nos próximos parágrafos serão comentadas e discutidas, pesquisas importantes da literatura que permitiram o amadurecimento do campo de estudos do ensino de Astronomia. Num primeiro momento iremos discutir o ensino fundamental, num segundo momento, o ensino médio e depois alguns trabalhos voltados para a graduação. Posteriormente, serão também discutidas as contribuições de trabalhos de ensino de Astronomia em espaços não formais como observatórios astronômicos e planetários. 


\subsection{Pesquisas de educação em Astronomia para o ensino funda- mental}

Um dos primeiros temas tratados em artigos de ensino de Astronomia foi o estudo das concepções de crianças sobre as formas e as características da Terra enquanto corpo cósmico. Esta pesquisa foi realizada no Estados Unidos com alunos da segunda série (9 anos de idade) por Nussbaum e Novak (1976). Posteriormente, esta mesma pesquisa foi repetida com alunos de outras culturas, ampliando a faixa etária pesquisada para incluir os alunos de quarta à oitava série (MALI; HOWE, 1979). Os resultados obtidos, nos trabalhos acima citados, indicaram que alunos com maior escolaridade e idade apresentaram concepções mais próximas às aceitas pela comunidade científica.

Buscando informações sobre as concepções dos alunos de temas além da Terra como estações do ano, fases da Lua, sucessão do dia e noite, Baxter (1989) realizou uma pesquisa na Inglaterra com crianças e adolescentes entre 9 e 16 anos, concluindo que a maior parte dos alunos crê que as fases da Lua ocorrem devido à sombra da Terra encobrir a Lua (confunde com as causas dos eclipses lunares) e as estações do ano ocorrem devido à maior ou menor proximidade da Terra ao Sol. Vosniaudou e Brewer (1992) realizaram um estudo sobre as concepções da Terra de alunos de primeira, terceira e quinta séries $(7,9$ e 11 anos) concluindo que a maior parte dos alunos não concebe a Terra como sendo esférica, tendo apresentado uma concepção mais próxima a de um disco. Em 1997, Vosniaudou juntamente com outros autores Diakidoy e Kendeou (1997) repetiram o estudo com filhos de índios americanos concluindo que a maior parte das crianças analisadas acreditam que a Terra seja oca por dentro, esta concepção é próxima à mitologia indígena pesquisada por estes autores.

Buscando entender as concepções de alunos brasileiros de dia e noite, estações do ano e a localização de corpos celestes no céu, Franco (1998) realizou uma pesquisa semelhante ao de Baxter (1989) no Rio de Janeiro em 1992, investigando alunos da pré-escola à universidade. O autor brasileiro notou que apenas crianças entre 4 e 7 anos apresentaram concepções de uma Terra plana. Nesta mesma faixa etária, foram constatadas concepções 
animistas e egocêntricas a respeito da sucessão do dia e noite. Em relação às estações do ano, a maioria das crianças nesta faixa etária não possui um modelo para explicá-las. Os estudantes mais velhos em geral afirmaram que as estações do ano ocorrem devido à excentricidade da órbita terrestre. O autor conclui o artigo chamando a atenção para a necessidade de se considerar as concepções prévias dos alunos no ensino de ciências, pois seria a partir da compreensão das limitações de suas concepções que estariam preparados para considerarem o potencial das ideias científicas.

Bisch (1998) em sua tese de doutorado realizou uma pesquisa sobre conceitos básicos de Astronomia abarcando todo o ensino fundamental desde os 6 até os 14 anos. Pesquisou também, os professores de escolas públicas do município de São Paulo que participaram de um curso de extensão universitária. Os resultados apontaram para uma evolução das concepções conforme a idade e escolaridade em direção às concepções aceitas pela comunidade científica. O autor constatou o uso frequente de chavões pelos professores que mal compreendiam o que estavam dizendo. Houve uma dissociação entre o céu - belo e familiar, com o Universo descrito nos livros didáticos - abstrato e distante, como se tratassem de dois temas desconexos. Os professores, assim como os alunos, frequentemente representavam os astros como sendo bidimensionais. O autor conclui a tese com o comentário de que é necessário um legítimo processo de formação continuada de professores para suprir a carência de conhecimento.

Já Trumper (2001) realizou uma pesquisa com alunos de Isreal com idades entre 13 e 14 anos sobre fases da Lua, estações do ano e sucessão do dia e noite. O autor concluiu que os alunos apresentaram pré-concepções acerca destes fenômenos bastante distintas das aceitas pela comunidade científica, aproximando-se de concepções ingênuas de senso comum. Este autor obteve resultados semelhantes a Sharp (1996) que investigou, por meio de entrevistas, concepções sobre estes mesmos temas apresentadas por crianças entre 10 e 11 anos na Inglaterra. Outro estudo realizado por Dove (2002) com crianças de 12 anos mostrou que a maior parte delas consegue explicar a sucessão do dia e noite, mas poucas são capazes de explicar porque a Lua apresenta sempre a mesma face voltada para a Terra, outro resultado obtido foi que boa parte dos alunos consegue explicar porque a estrelas 
se movem no céu, mas não o sentido e direção do movimento.

Outro trabalho que merece destaque na literatura brasileira é o de Leite (2002) que pesquisou os conceitos básicos de Astronomia de professores da rede pública do município de São Paulo em sua dissertação de mestrado. Muitos professores concebem a Terra como sendo plana e os poucos que a consideram esférica, a desenharam com um exagerado achatamento nos polos, além disso, muitos professores acreditam que a distância da Terra ao Sol é a causa principal das estações do ano. Além de conceberem as estrelas como sendo corpos de natureza distintas a do Sol. Assim como Bisch (1998), Leite (2002), chama a atenção para a necessidade urgente de programas de formação continuada de professores especialmente devido à proposição destes tópicos no currículo escolar pelos PCNs.

Langhi (2004) em sua dissertação de mestrado realizou uma pesquisa em que entrevistou professores dos anos iniciais do ensino fundamental, sobre como lecionavam temáticas de Astronomia nas aulas de ciências e seus conhecimentos sobre o tema. O autor constatou que muitos dos professores entrevistados gostariam de saber mais sobre o assunto e que lecionavam o tema com muita insegurança. Em sua pesquisa ele também ressaltou a importância de se inserir a Astronomia dentro dos conteúdos do currículo escolar por se tratar de um tema interdisciplinar e alertou para necessidade de programas de educação continuada para os professores.

Dando continuidade ao seu trabalho Leite (2006), em sua tese de doutorado, analisou uma das principais dificuldades dos professores e alunos em aprender Astronomia, a noção de espacialidade. Desenvolveu um curso de preparação para professores do ensino fundamental do município de São Paulo constatando que as maiores dificuldades dos professores foram relativas à compreensão de como ocorrem as fases da Lua devido à necessidade de mudança de referencial e poucas noções de espacialidade.

Um trabalho brasileiro recente, que também analisou as pré-concepções sobre estações do ano, fases da Lua, eclipses e sucessão do dia e noite apresentadas por alunos de quinta série do ensino fundamental de uma escola particular em São Paulo foi realizado por Scarince e Pacca (2006). A metodologia das aulas foi construtivista com atividades de campo de observação do céu noturno. O curso foi positivo para os alunos, uma vez que 
eles foram capazes de apontar erros em livros didáticos, além de elaborarem e discutirem seus modelos sobre o céu com a professora e colegas.

Numa pesquisa recente Plummer (2008) examinou as concepções de movimentos celestes aparentes de alunos de primeira, terceira e oitava séries dos Estados Unidos. Para isto usou uma pequena redoma que representava o céu, que permitiu aos alunos que demonstrassem suas ideias. A autora constatou que os alunos apresentaram uma variedade de ideias não científicas a respeito dos movimentos dos astros havendo uma significativa diferença nas concepções dos alunos de primeira série em relação à terceira série, mas notou que ao mesmo tempo houve pouco progresso em relação às concepções dos alunos de terceira série comparado aos de oitava série.

Pelo exposto acima, vemos que investigar maneiras de se ensinar sobre o Sol e noções de física solar para alunos do ensino fundamental é uma necessidade urgente para a melhoria do ensino de Astronomia.

\subsection{Pesquisas de educação em Astronomia para o ensino médio e superior}

Barrabáin (1995) realizou uma pesquisa semelhante a de Baxter (1989) em Barcelona com jovens entre 12 e 18 anos focando seu estudo nas concepções de estações do ano e o modelo Terra-Sol. A maior parte dos alunos afirmou que a órbita em torno da Terra se assemelha mais a uma elipse bem achatada do que a um círculo, com o Sol em um de seus focos. Outro resultado semelhante ao obtido por Baxter (1989) foi que o verão ocorre quando a Terra está mais perto do Sol e o inverno quando a Terra se encontra mais longe do Sol. López (1995) investigou as concepções de alunos de 14 a 18 anos sobre a forma, tamanho, origem e evolução do universo. Estes alunos já sabiam um pouco de Astronomia e ainda assim, a maior parte deles acreditava que o universo fosse heliocêntrico.

Oliveira et. al. (2007) fizeram um estudo do conhecimento astronômico de alunos do ensino médio de escolas estaduais da cidade de Suzano em São Paulo. Os resultados mostraram que apenas 29,4\% dos alunos compreenderam o motivo astronômico do dia 
e noite, 20,6\% conseguiram explicar as estações do ano, 20,6\% tinham uma noção de quais são os corpos celestes mais próximos da Terra e 67,6\% classificaram o Sol como uma estrela. Outro resultado encontrado na pesquisa dos autores mostrou que a escola foi o principal meio pelo qual os alunos adquiriram seus conhecimentos. Outras fontes de conhecimento dos alunos apontadas pelo autor foram filmes e programas de televisão.

Um dos poucos artigos sobre ensino de astrofísica é o de Schatz e Lawson (1976), este trata sobre o diagrama Hertzprung-Russel (pode ser usado para determinar a trajetória evolutiva de uma estrela) com alunos entre 17 e 20 anos. Seu estudo mostrou que os alunos não sabem interpretar o diagrama, acreditando que as estrelas literalmente se movem pelo espaço e que estrelas maiores, como as gigantes vermelhas, sempre possuem maior massa que as anãs independentemente de suas trajetórias evolutivas.

Outro trabalho que lidou com o tema de astrofísica foi o de Agan (2004), onde a autora buscou compreender as concepções de alunos do ensino médio e do primeiro ano de graduação sobre as estrelas. Os resultados obtidos no trabalho mostraram que os alunos do ensino médio que não fizeram nenhum curso de Astronomia, definem as estrelas por meio de características sensoriais, como tamanho e cor, enquanto que os alunos de graduação, que passaram por algum curso de Astronomia as definem de acordo com o processo de produção de energia.

As concepções de Astronomia de alunos do ensino superior foram investigadas por Pedrochi (2005) e demonstraram que os estudantes tendem a memorizar conceitos de Astronomia sem entendê-los e a possuírem muitas concepções alternativas. Um problema apontado pelos autores é a ausência de uma discussão durante os cursos de licenciatura e bacharelado do uso de diferentes referenciais para enxergar um mesmo movimento, o que reforça os esquemas de memorização sem entendimento.

No trabalho de Bailey (2008) foram investigadas as concepções sobre estrelas de alunos de graduação pertencentes a cursos que não estavam relacionados as ciências naturais de uma universidade americana. O estudo mostrou que possuem uma idéia a respeito de propriedades básicas de uma estrela, como sendo constituída por gases, mas a maior parte deles não sabe que uma estrela produz energia por fusão nuclear. 
De maneira geral, os poucos trabalhos que tratam do ensino de Astronomia no ensino médio e superior, também não abordam o ensino de física solar de forma adequada.

\subsection{Pesquisa sobre ensino de Astronomia em espaços não for- mais de educação}

Na literatura internacional, a maior parte dos trabalhos de ensino de Astronomia em espaços não formais são sobre o ensino dentro de planetários. Dentre estes trabalhos podemos citar o de Reed e Campbell (1972) que compara o aprendizado de Astronomia em sala de aula e num planetário. Outro trabalho é o de Sunal (1976) explicando a importância do ensino de Astronomia em um planetário complementando o ensino em sala de aula. Fletcher (1980) e Baxter e Preece (2000) comparam, em seus artigos, maneiras diferentes de se ensinar Astronomia dentro de um planetário por participação dos visitantes e usando programas distintos para planetários.

Já o estudo de Burtnyk (2000) foi realizado em um observatório da Austrália para se determinar quais tipos de públicos visitam este espaço e os motivos das visitas. Os visitantes foram entrevistados e os autores concluíram que as visitas ao observatório serviram de motivação para retornarem e aprenderem mais Astronomia.

Analisando os ganhos cognitivos de alunos que participaram de um acampamento em um observatório astronômico nos Estados Unidos, Fields (2008) descreve como as atividades de pesquisa orientadas por astrônomos amadores e profissionais trouxeram benefícios aos estudantes. Dentre estes ganhos a autora comenta sobre relacionamento em grupo, autonomia pessoal, relacionamento positivo com a equipe organizadora e um aprofundamento de conhecimento científico. Tais benefícios parecem influenciar nos tipos de identidades que os estudantes constroem para si mesmos em relação à ciência. Ao mesmo tempo demonstrou a importância dos espaços não formais como meios de aproximar estudantes da comunidade científica.

No âmbito nacional, os trabalhos de pesquisa em ensino de Astronomia em espaços não formais foram realizados principalmente em observatórios e museus de Astronomia. 
Como o estudo de Gonzales (2004) e Bulgarelli e Haun (2007) que tiveram como objetivo despertar o interesse pela ciência de alunos em visitas monitoradas ao Observatório do Valongo por meio de cursos oferecidos a crianças de 6 a 9 anos na Fundação Planetário, ambos do Rio de Janeiro. As atividades desenvolvidas em ambas instituições foram a confecção de relógios solares, observação de manchas solares e uma pequena sessão de planetário. Os resultados obtidos pelos autores foram bastante positivos, ou seja, segundo eles, as instituições estão cumprindo o objetivo de estimular o interesse das crianças pelas ciências, uma vez que retornaram aos museus de ciências.

Marandino et. al. (2003) por sua vez, analisaram o processo de transposição museográfica em duas exposições do MAST (Museu de Astronomia e Ciências Afins) concluindo que na exposição "Ciclos astronômicos e a vida na Terra" a atenção dos visitantes foi norteada por assuntos mais relacionados com suas histórias de vida do que com a proposta pelos idealizadores das exposições. Já, na exposição "Estações do ano: a Terra em movimento", houve interação dos visitantes, reconhecendo as marcas de intencionalidade dos idealizadores.

Outro trabalho realizado no MAST foi o de Falcão et. al. (2004) que procurou analisar algumas exibições sobre estações do ano e sucessão do dia e noite, a partir de modelos mentais de alunos de terceira à oitava série em excursões de escolas ao museu. Questionários escritos foram aplicados, antes e alguns meses após as visitas e houve também, entrevistas semiestruturadas sobre os tópicos abordados durante as excursões.

Um dos colegas de nosso grupo de pesquisa, Colombo Júnior (2007) investigou as visitas orientadas diurnas ao Observatório do CDCC/USP em São Carlos. Em sua pesquisa procurou encontrar as maiores dificuldades enfrentadas pelos alunos do ensino fundamental (9 e 10 anos) na aprendizagem de conceitos astronômicos e a melhor maneira de sanar estas dificuldades. Para isso foi usada uma metodologia de pesquisa qualitativa apoiada em observação, aplicação de questionários e entrevistas semiestruturadas. Os resultados demonstraram que é difícil para as crianças construírem noções de espaço e distâncias no Sistema Solar. Por outro lado, a atividade motivou os alunos a retornarem com seus familiares ao Observatório. Este trabalho evidenciou a importância da atuação de centros 
de ciências no ensino de Astronomia.

Pelos trabalhos discutidos acima, constatamos que há pouquíssimas pesquisas em ensino de Astronomia em espaços não formais envolvendo o ensino de astrofísica. Não foram encontradas na literatura pesquisas relacionadas às concepções de manchas solares, proeminências ou espectro solar, sejam em espaços formais ou não formais. Esperamos com este trabalho de pesquisa enriquecer este campo de atuação e quem sabe, servir de inspiração para outros trabalhos semelhantes.

No próximo capítulo são discutidos os principais referenciais teóricos de museus de ciências que foram adotados nesta pesquisa, uma vez, que é necessário um olhar diferenciado para a educação que ocorre em museus de ciências em relação à educação que ocorre em sala de aula. 


\section{Educação em museus de ciências}

Os museus de ciências são importantes locais de conhecimento e contribuem para o enriquecimento da cultura. Geralmente, nestes espaços as pessoas são livres para visitálos, ou seja, a educação é guiada pelos desejos de cada um, em um ambiente projetado para difundir uma determinada proposta temática científica ou tecnológica. Nestes estabelecimentos, a educação se diferencia da escolar por haver a possibilidade de observar, ler ou mesmo escutar tópicos específicos da exposição do museu que são de interesse do indivíduo e não impostos pelo professor ou currículo.

Antes de discutirmos a educação em museus de ciências julgamos prudente descrever um pouco do desenvolvimento nestes espaços a fim de os situarmos historicamente.

\subsection{Um pouco da história de museus de ciências no Brasil}

Os primeiros passos na implementação de museus de ciências no contexto brasileiro ocorreram a partir da ampliação do ensino de ciências e da divulgação científica na década de sessenta do século passado, quando houve uma demanda de equipamentos e materiais para ministrar as disciplinas de ciências na escola, com o uso de laboratórios didáticos. A carência de laboratórios e de equipes preparadas seria suprida, em parte, pelos museus e centros de ciências que forneceriam kits com experimentos para os professores usarem em sala de aula, atualização do currículo de ciências e promoção de cursos de extensão. Segundo Gaspar (1993), grande parte das iniciativas teve como ponto de partida a criação no ano de 1950, em São Paulo do Instituto Brasileiro de Educação, Ciência e Cultura (IBECC) vinculado à Universidade de São Paulo e à UNESCO. Ainda assim, o alcance de suas atividades foi bastante limitado.

Outra mudança que favoreceu a criação de museus de ciências na década de sessenta foi que o ensino passou a atender camadas mais amplas da população com o intuito não mais de formar cientistas, buscando ao invés disso, o conhecimento para todos, de acordo com a Lei 4.024 de Diretrizes e Bases da Educação de 21 de dezembro de 1961. Esta lei alme- 
java uma população adulta que não fosse somente capaz de ler e escrever, mas que fosse também matemática, científica e tecnologicamente alfabetizada, visto que isso tornaria os indivíduos menos dependentes uns dos outros, fazendo com que os processo democráticos, os valores sociais e as oportunidades individuais não permanecessem dominadas pelas elites culturais. Para que isto se tornasse possível foi fundamental elaborar e implementar programas de educação escolar e atividades além de sala de aula que pudessem contribuir para a formação de cidadãos críticos (CAZELLI; MARANDINO, 2003).

Com o golpe militar e a instauração da ditadura no Brasil em 1964 houve uma mudança no papel da escola. Esta deixou de enfatizar a cidadania e passou a considerar a formação do trabalhador onde as disciplinas de ciências adquiriram um caráter profissionalizante, isto foi sancionado com a Lei de Diretrizes e Bases da Educação n. 5692 de 1971. Mas, com a democratização novamente o enfoque escolar mudou propiciando a criação de uma nova Lei de Diretrizes e Bases da Educação n 9394/96 de 1996. Segundo esta nova lei, a prática escolar deveria vincular-se ao mundo do trabalho e à prática social (KRASILCHIK, 2000). O aluno deveria estudar conteúdos relevantes para sua vida, no sentido de identificar os problemas e buscar soluções para os mesmos.

O marcante para história dos museus no Brasil foi a década de oitenta, quando houve a proliferação de diferentes tipos de museus. Nesta década foram criados o Espaço Ciência Viva e o Museu de Astronomia e Ciências Afins no Rio de Janeiro, o Centro de Divulgação Científica e Cultural (CDCC/USP), Estação Ciência e o Museu Dinâmico de Ciências de Campinas no estado de São Paulo. Estes museus foram concebidos com o intuito de atender ao público, em especial o escolar desenvolvendo ações educativas em diferentes níveis. Mas, foi somente na década de noventa que as ações promovidas pelos museus de ciências ganharam firmeza e reconhecimento governamental e privado de instituições como CNPq, FAPESP, Fundação Vitae e outros. O "fazer aprendendo" amplamente divulgado nos meios de educação construtivista, passou a adquirir no museu de ciências, um caráter mais dinâmico que na própria escola. Nesta década foram criados no país: o Espaço Museu do Universo, Espaço Museu da Vida no Rio de Janeiro, Museu de Ciência e Tecnologia no Rio Grande do Sul e Espaço Ciência em Pernambuco dentre outros. 
No ano de 2008, o CNPq lançou o edital MCT/SECIS/CNPq n 63/2008, com o objetivo de apoiar financeiramente projetos de divulgação científica na área de Astronomia, que atende prioridades estratégicas do Governo Federal de “ [...] estimular a popularização da ciência e tecnologia e de promover a melhoria da educação científica e as comemorações do ano internacional da Astronomia (2009)". Dentre as linhas temáticas de financiamento estão a elaboração e/ou aquisição de materiais destinados a atividades de divulgação de Astronomia, promoção de eventos e outras atividades de divulgação de Astronomia, implantação de espaços destinados à popularização da Astronomia, produção e distribuição de materiais didáticos de divulgação de Astronomia. Com isto é possível perceber uma crescente valorização do ensino e divulgação de Astronomia em espaços não formais pelo governo brasileiro.

\subsection{Educação em museus de ciências}

Apesar de os museus de ciências existirem antes mesmo do século XIX, as pesquisas de como ocorre a educação nestas instituições começaram somente nas décadas de setenta e oitenta do século passado. Ainda assim, os estudos foram baseados em modelos de ensino e aprendizagem em sala de aula. Houve uma preocupação em medir o quanto o aluno aprendeu de determinado tópico, numa abordagem simples e fácil de ser aplicada. No entanto, estes estudos assumem que o aluno estaria intelectual e emotivamente prédisposto a aprender determinado tópico, que o indivíduo de fato entendeu o tópico e que a mudança na compreensão seria sempre mensurável como sendo uma adição quantitativa de informações. No entanto, o ensino e aprendizagem em museus de ciências são muito mais complexos. Como no museu o indivíduo pode ver a exposição que quiser, sua aprendizagem é fortemente influenciada pelo que já sabe e o que deseja aprender, além de outros fatores que iremos discutir neste capítulo. Portanto, não podemos aplicar aos museus de ciências, as mesmas ferramentas usadas para investigar o ensino e aprendizagem em sala de aula (FALK; STORKSDIECK, 2005).

A constatação de que a aprendizagem que ocorre nas escolas não é a mesma que 
ocorre em museus, repercutiu na criação de duas denominações distintas; a de educação formal que ocorre em sala de aula, e a de educação informal, que ocorre fora da escola. Alguns autores, em especial de língua latina, acrescentaram uma terceira denominação, a de educação não formal, como sendo aquela restrita à educação em museus, centros de ciências e cursos que ocorrem além da sala de aula. Para estes mesmos autores, a educação informal é aquela que ocorre em casa ao ler um livro, consultar uma página da internet, ou mesmo em um clube com amigos (CAZELLI; FRANCO, 2001). Em muitos países de língua inglesa, o termo ensino não formal não é muito conhecido, e os autores preferem adotar ao invés desta terminologia, o de educação informal, educação comunitária ou pedagogia social (SMITH, 2001).

A fim de caracterizar o ensino e aprendizagem que ocorre em espaços fora da sala de aula, Falk (2001) introduziu o termo "free-choice learning" (aprendizagem por livre escolha). Segundo este autor, o "free-choice learning" seria uma aprendizagem em que o indivíduo busca conhecimento, devido a interesses próprios e não por motivos impostos pela escola ou sociedade. O que faz a aprendizagem diferente, segundo Falk (2001), é parcialmente o espaço físico, mas igualmente importante é o contexto social e a motivação do aprendiz. Ou seja, a aprendizagem do tipo "free-choice" pode ocorrer em museus de ciências, sendo característica de uma educação não formal ou em outros ambientes, como em casa sendo caracterizada por uma educação informal.

Neste trabalho optamos por adotar a definição de ensino não formal da língua portuguesa e o termo "free-choice learning" por diferenciar a educação que ocorre em museus de ciências, da educação em sala de aula, da educação informal em geral.

O tema educação em museus de ciências é bastante amplo, nesta pesquisa iremos apresentar apenas alguns aspectos que julgamos relevantes para este trabalho. Os referenciais teóricos de museus de ciências são voltados para um estudo do ensino e aprendizagem que ocorre antes, durante e após as visitas às exposições nestes espaços. Neste trabalho de pesquisa adotamos alguns dos referenciais teóricos de aprendizagem em museus de ciências adaptando-os para aplicá-los, não em exposições, mas em cursos desenvolvidos em um observatório astronômico. 
Braund e Reiss (2006) propõem cinco contextos fora da escola que contribuem para a aprendizagem de ciências. Nesta pesquisa iremos discutir apenas quatro que julgamos relevantes para nosso trabalho, são estes:

- Desenvolvimento aprimorado e integrado de conceitos.

- Atividades práticas estendidas e autênticas.

- Atitudes para a ciência na escola: estimulando um aprendizado que vai além da escola.

- Implicações sociais: trabalho colaborativo e responsabilidade em aprender.

O quinto contexto fora da escola proposto por Braund e Reiss (2006) (não adotado por nós) é o acesso a materiais raros e à "grande" ciência.

\section{Desenvolvimento aprimorado e integrado de conceitos}

Uma crítica bem conhecida envolvendo o aprendizado em museus de ciências é afirmar que os visitantes ficam tão entretidos com o que estão vendo que raramente prestam atenção na relevância científica do aparato experimental, podendo muitas vezes, desenvolver pré-concepções equivocadas sobre o que estão observando. Ou seja, o lúdico passa a ser mais valorizado que o conteúdo científico.

Para os autores da crítica, parece ser difícil conseguir realizar atividades fora da escola com a intenção de motivar e entreter o aluno e ao mesmo tempo promover um aprendizado dos conceitos e leis da ciência. Mas, não é este o problema que todos os professores enfrentam em quase todas as aulas na escola? Um trabalho desenvolvido por Falk et. al. (1998) ${ }^{1}$ apud BRAUND; REISS (2006) mostraram que os ingredientes corretos para uma aprendizagem significativa são a motivação educacional e o entretenimento. Onde as motivações intrínsecas (por exemplo, interesse no tópico estudado) e não motivações extrínsecas (por exemplo, para passar num exame) estão ligadas a ganhos cognitivos.

\footnotetext{
${ }^{1}$ FALK, J.; COULSON, D.; MOUSSOURI, I. The effect of vistors agendas on museum learning. Curator, v. 41, n. 2, p. 106-120, 1998.
} 
Os cursos oferecidos ao longo deste trabalho atraíram os alunos por motivações intrínsecas, na medida em que foram cursá-los voluntariamente movidos por interesses próprios. Concordamos com Braund e Reiss (2006) que desta forma, a aprendizagem ocorre mais facilmente do que se os cursos fossem impostos pela escola.

\section{Atividades práticas estendidas e autênticas}

As atividades práticas estendidas, para Braund e Reiss (2006), são aquelas impossíveis de se realizar na escola por diversos motivos. Ensinar Astronomia apenas em sala de aula limita a aprendizagem de conceitos como o movimento dos astros, dinâmica de fenômenos que ocorrem no Sol, como manchas solares e proeminências, observação do espectro solar etc. Tais assuntos quando abordados apenas pelo livro didático tornam-se abstratos e distantes da realidade dos estudantes, que passam a enxergá-los como conhecimentos inúteis. Mas, se ao contrário, tiverem oportunidade de observarem o movimento dos astros, noite após noite, acompanhar o movimento de manchas e proeminências no Sol, ou mesmo observar o espectro solar, estes conhecimentos, muitas vezes, tornam-se interessantes, motivantes fazendo com que novas ideias e questões surjam na mente dos jovens, propiciando assim o verdadeiro aprendizado dos temas propostos.

Os PCNs incentivam a prática de atividades de observação que não podem ser realizadas em sala de aula e buscam além de atividades escolares, a contextualização dos tópicos ensinados em sala de aula por meio de atividades fora da escola. Estas atividades ajudam o aluno a entender a importância histórica e a beleza do tópico ensinado, pois favorecem conexões entre o que ele aprende em sala de aula com seu cotidiano e com aplicações na sociedade.

Com relação à Astronomia no ensino fundamental os PCNs recomendam que, "os alunos devem identificar, mediante observação direta algumas constelações, estrelas e planetas recorrentes no céu do hemisfério Sul durante o ano, compreendendo que os corpos celestes vistos no céu estão a diferentes distâncias da Terra; valorizar o conhecimento historicamente acumulado, considerando o papel de novas tecnologias e o embate de ideias nos principais eventos da história da Astronomia até os dias de hoje" (BRASIL, 1998). A 
partir de observações e de discussões com os alunos é possível, por exemplo, que compreendam a importância dos astros para as grandes navegações, que serviram de orientação aos navegantes para chegarem a seus destinos e as dificuldades atuais em se construir naves capazes de transportar o homem para outros corpos além do Sistema Solar devido às imensas distâncias envolvidas.

Os cursos elaborados nesta pesquisa enfatizaram a observação do Sol por meio de atividades que exigiram equipamentos próprios e conhecimentos específicos de como observar o Sol por um telescópio. Portanto, são atividades impossíveis de realizar dentro da sala de aula. Tais atividades permitem contextualizar os conhecimentos sobre o Sol e seu espectro tornado-os parte da realidade dos alunos e não apenas conceitos abstratos presentes em livros didáticos.

\section{Atitudes para a ciência na escola: estimulando um aprendizado que vai além da} escola

O aprendizado é raramente um evento instantâneo, mas sim um processo cumulativo que demanda tempo. É também uma experiência pessoal construída a partir de fatores externos (mundo físico, contexto histórico) e internos (pensamentos, motivações). Sendo assim, a questão que deve ser feita não é somente se o visitante aprende ciência numa visita a um museu de ciências, mas sim, como o museu de ciências ajuda o visitante a desenvolver uma atitude mais positiva em relação à ciência. É mais importante entender como o visitante emprega os recursos do museu com a finalidade de produzir um significado próprio por meio de experiências e como estas últimas contribuem para relacionamentos mais amplos entre ideias próprias e às questões de ciências. Assim, é possível abordar a questão de como o museu influencia o visitante a partir de um contexto mais abrangente (FALK, 2001).

Os contextos fora da sala de aula estimulam os estudantes a promoverem novas conexões com a ciência, pensando mais sobre o tema e suas implicações para a sociedade. Quando os alunos estão bem orientados pelos contextos de aprendizado fora da escola, o próprio aprendizado dentro deste espaço torna-se mais eficiente (BRAUND; REISS, 2006). 
Constatamos que após a realização dos cursos sobre o Sol, alguns alunos retornaram ao Observatório para participarem de outras atividades, como observação do céu noturno e assistiram a palestras sobre Astronomia. Para estes alunos, o curso de observação solar foi positivo ao atraí-los para outros temas de Astronomia e outros ramos da ciência.

\section{Implicações sociais: trabalho colaborativo e responsabilidade em aprender}

A escola possui os conteúdos distribuídos de forma fragmentada em função do tempo restrito e da constante aplicação de exames. As atividades realizadas fora da sala de aula, por não se aterem aos sistemas de avaliação e disporem de mais tempo, proporcionam, mais autonomia aos estudantes, fazendo com que os mesmos possam trabalhar de forma colaborativa em grupos. Isto desperta nos alunos a consciência de que aprender ciências ultrapassa as barreiras da sala de aula (BRAUND; REISS, 2006).

Nos cursos realizados neste trabalho podemos citar o exemplo da atividade desenvolvida com os alunos do ensino médio de estimar o diâmetro do Sol que envolveu um trabalho colaborativo.

A ciência tem se mostrado difícil de ser compreendida. Mas, o desenvolvimento de conceitos de ciências em ambientes novos, motivadores como o Observatório Astronômico do CDCC/USP despertam o interesse dos alunos facilitando a sua aprendizagem.

\subsection{Museus de ciências na contextualização do currículo escolar}

Uma categoria específica de visitantes é a escolar. Esta categoria se diferencia da visita ao museu realizada com a família, amigos ou solitária pelo fato de as classes visitantes, muitas vezes, não terem uma plena escolha sobre o que desejam explorar dentro do museu de ciências. Já que as visitas são geralmente guiadas e orientadas e desta forma é a categoria que mais se aproxima dos cursos oferecidos e investigados em nossa pesquisa. Uma vez que os alunos são todos de mesma escolaridade, e a visita assim como o curso, geralmente é estruturado com começo, meio e fim, seguindo a um roteiro de atividades que visa alcançar objetivos pré-estabelecidos. 
Braund e Reiss (2006) ressaltam a necessidade de incluir no currículo de ciências atividades fora da sala de aula, como visitas a museus de ciências que tenham relação com os tópicos ensinados na escola. Pois, segundo eles, como os alunos encaram a ciência ensinada na escola como sendo ultrapassada, irrelevante e sem graça, eles são muitas vezes desmotivados pela forma em que a ciência é ministrada na escola. Por outro lado, a maneira pela qual a ciência é comunicada fora da escola é vista como atraente, motivadora e desafiante. O que determina um aprendizado diferenciado do escolar é parcialmente o espaço físico, mas talvez o mais importante, seja a forma pela qual a ciência é ensinada, o contexto social e a motivação do aprendiz.

As crianças e adolescentes passam 2/3 de seu tempo fora da escola. Isto muitas vezes, não é considerado pelo professor ao ensinar ciências. O educador, muitas vezes, ignora as crenças, atitudes e motivação da aprendizagem do assunto fora da escola (BRAUND; REISS, 2006). Segundo Falk e Dierking (2000); "o aprendizado é um diálogo entre o indivíduo e seu contexto social cultural e ambiente físico." Como na escola muitas vezes não existe este diálogo envolvendo o cotidiano do aluno e o que está sendo ensinado, o aluno passa a ver a escola como algo distante de sua realidade e desta forma não a incorpora como fonte de conhecimento esquecendo rapidamente o que lhe foi ensinado.

Braund e Reiss (2006) propõem que a ciência ensinada fora da escola seja incorporada ao currículo como um complemento ao ensino formal e não como uma competição entre os dois tipos de ensino. Argumentam que o ensino na escola está moldado de forma arcaica e restrita. Além disso, toda a ciência é ensinada como se o laboratório fosse o principal fator motivador e estratégia necessária para o aprendizado de ciências, não considerando as influências do aprendizado além deste ambiente.

Durante as décadas de cinquenta, sessenta e setenta prevaleceu a idéia de um ensino experimental de ciências caracterizado pela ênfase no método científico, composto por passos bem determinados; identificação de problemas, elaboração de hipóteses e verificação experimental das mesmas permitindo chegar a um resultado e levantar novas questões (KRASILCHIK, 2000). No caso de um currículo que focalizou primordialmente a transmissão de conteúdo, o trabalho no laboratório foi motivador ao desenvolver habilidades 
técnicas e auxiliar na fixação do conhecimento sendo estudado. Com as influências das teorias cognitivistas, o laboratório passou a ser encarado como elemento de aferição do estágio de desenvolvimento do aluno e da ativação do progresso ao longo destes estágios e do ciclo de aprendizagem.

Braund e Reiss (2006) enfatizam que os laboratórios foram o suficiente para a população escolar da década de 60, mas que hoje em dia os alunos sabem que o conhecimento pode ser obtido de outras maneiras, e assim usar apenas o laboratório como demonstração da produção do conhecimento científico tornou-se insuficiente. Muitos alunos inteligentes afirmam que a ciência não é para eles. O que estão rejeitando não é a ciência em si, mas uma imitação pálida da mesma (BRAUND; REISS, 2006).

Em muitas classes de laboratório os alunos obedecem cegamente às regras impostas pelo professor e raramente se dispõem a pensar sobre o que estão fazendo e o método que estão empregando no experimento. Um controle excessivo por parte do professor desencadeia estudantes menos capacitados em conduzir testes científicos próprios, menos capazes de apreciarem as relações intrincadas existentes entre ciência, tecnologia, ambiente, sociedade e menos capazes de agir de forma crítica (BENCZE; HODSON, 1999).

Compartilhamos com Braund e Reiss (2006) que uma das maneiras de encarar o laboratório na escola é o de descontextualizar o contexto em que a ciência é tradicionalmente ensinada. A ciência real passa a ser aquela que é abstrata. O mundo real é visto como um envelope imperfeito no qual a ciência encontra-se embrulhada. A maneira em que os cursos de ciências são organizados especialmente no ensino médio e nas universidades é baseada na visão do cientista, ou seja, não a do estudante. O foco dos cursos são os conceitos científicos. Mas para o estudante, muitas vezes, o ponto relevante é para que se estudar isto, ou seja, o contexto em que o conteúdo científico está inserido e nem tanto, o conteúdo em si (HART, 2002).

Segundo Braund e Reiss (2006), há um consenso entre os educadores que deveria haver mais experimentos similares aos desenvolvidos por cientistas no currículo escolar. No entanto, a maior parte destes experimentos não poderiam ser desenvolvidos na escola tendo o professor que recorrer a atividades além de seu espaço. No contexto brasileiro, a 
situação é ainda mais grave, uma vez que as escolas públicas em geral não são equipadas com laboratórios de ciências. Isto intensifica ainda mais a necessidade de educação em espaços não formais na vida da população brasileira.

Nos cursos oferecidos nesta pesquisa buscamos mostrar aos alunos a relevância de se estudar o Sol e física solar por meio de experimentos que permitiram contextualizar o conhecimento pelo uso de atividades relativamente abertas e que exigiram a participação cognitiva dos alunos.

\subsubsection{A importância da parceria museu de ciências e escola}

Para que a aprendizagem de turmas de alunos em visitas a museus de ciências seja eficiente é imprescindível que haja colaboração entre o educador de museu e o professor. Pesquisa realizada por Griffin (1997) revelou que os alunos tendem a refletir o comportamento do professor em visitas a museus. Ou seja, se o professor está entusiasmado e familiarizado com a exposição em geral, os alunos também estarão, mas se ao contrário, o professor estiver no museu apenas com a função de cumprir uma agenda, os alunos também se sentirão desta forma. Sendo assim, é imperativo que o professor saiba o que os alunos vão explorar e se interesse pelo material apresentado, para tanto há necessidade de um diálogo com os educadores do museu antes de levar a turma de alunos para a visita.

Atualmente, existe pouca comunicação entre professor e educador de museu, o que torna difícil incorporar o que foi mostrado no museu ao currículo escolar (TRAN, 2007).

Professores de escolas e educadores de museus precisam dialogar em busca de um ensino e divulgação eficiente que possa aliar o que está sendo exibido no museu de forma que não apenas desperte o interesse dos alunos para o tema abordado como também promova conexões entre o que está sendo e foi estudado em sala de aula. Um estudo realizado por Griffin (2004) mostrou que o preparo das atividades do museu em conjunto com os professores aumenta as chances de aprendizado e proporciona envolvimento dos estudantes com o museu. 


\subsubsection{Maximizando o potencial educativo de visitas escolares aos museus de ciências}

Com a intenção de maximizar o potencial educativo de visitas de classes a museus Bamberger e Tal (2006) fizeram uma pesquisa classificando as visitas escolares em três tipos, são estas: "free choice, limited choice" ou "no choice".

A visita do tipo "free choice" é aquela na qual o visitante está livre para explorar qualquer parte da exposição que desejar e os mediadores possuem a função maior de responderem às perguntas do público.

Já o "limited choice" é uma visita em que os estudantes assistem a uma palestra sucinta relacionada à temática da exposição do museu, em seguida recebem exercícios para aplicar os princípios discutidos na palestra. Além disso, participam de atividades propostas pelos educadores do museu envolvendo jogos educativos, explorando regiões específicas do museu e brincadeiras do tipo "mão na massa" com a finalidade de aprender ciências.

Por fim, a visita "no choice" consiste numa visita na qual o mediador conduz os alunos pela exposição falando constantemente sobre o que está sendo visto, sem que os alunos possam escolher o que acham mais interessante ou propor outro tema de apresentação.

Bamberger e Tal (2006) concluíram que a visita escolar do tipo "limited choice" foi a mais educativa e interessante para os alunos. Uma vez que a visita "no choice" foi cansativa resultando numa maior dispersão dos estudantes durante as apresentações e menor formulação de perguntas ao instrutor do museu. A visita "free choice" foi a mais divertida segundo os alunos que participaram da pesquisa, porém neste tipo de atividade, os alunos afirmaram não terem aprendido muito, sentindo-se um pouco frustrados. Durante a visita "limited choice" os alunos expressaram um grande envolvimento com o que estava sendo ensinado.

Apesar de os cursos sobre o Sol não serem voltados para classes de alunos, podemos afirmar que adotamos uma abordagem do tipo "limited choice" com os alunos voluntários que participaram dos cursos. Pois houve discussões constantes, durante as observações os alunos foram guiados pela professora a respeito da maneira mais segura de observar o Sol, 
que detalhes se ater no disco solar e no registro de observações solares. Além disso, foram desenvolvidas atividades, como, por exemplo, estimar o diâmetro do Sol e a temperatura da fotosfera em que os alunos em grupos discutiam a melhor maneira de se realizar os experimentos e os dados obtidos.

É imprescindível pensar e refletir mais sobre os potenciais além da sala de aula e do laboratório escolar. Se isto for considerado existe uma grande chance de que as discussões dos professores com alunos em sala de aula complementem o que foi e está sendo aprendido fora da escola. Para que isto seja possível é imperativo que haja contato entre os cientistas, divulgadores de ciências, pesquisadores e professores que compartilham de um interesse em comum: o de ensinar ciências. É desejável que o museu de ciências ressalte as facetas da ciência que são pouco exploradas na escola, mostrando a ciência como relevante para a vida do aluno, contextualizando social e historicamente o conhecimento ensinado em sala de aula (JENKINS, 2001).

\subsection{Referenciais teóricos de aprendizagem em museus de ciên- cias adotados neste trabalho}

Como já foi discutido, as pesquisas de aprendizagem em museus de ciências realizadas a partir do século XX adotaram sem sucesso, estratégias de avaliação de educação escolar. Medir a aprendizagem nesses espaços envolve diversas variáveis que mudam de pessoa para pessoa e portanto, se faz necessário o uso de outras ferramentas de estudo diferentes das usadas para avaliar a aprendizagem no ensino formal (FALK; STORKSDIECK, 2005). Nos parágrafos seguintes, serão discutidos alguns dos referenciais teóricos de aprendizagem em museus de ciências adotados nesta pesquisa.

A partir da década de setenta, o ensino passou a ser influenciado pelas teorias construtivistas de Piaget, Bruner, Vygotsky, Gardner e outros. Optamos nesta seção discutir apenas as ideias construtivistas de Piaget e Vygotsky por serem referenciais teóricos bastante recorrentes na pesquisa em ensino de Astronomia, facilitando a comparação dos dados obtidos neste trabalho, com os de outros autores que os adotaram. Posteriormente, 
a esta discussão iremos apresentar o Modelo Contextual de Aprendizagem de Falk e Dierking (2000), principal referencial teórico desta pesquisa.

Concordamos com a posição assumida por Vygotsky de que a aprendizagem não pode ser entendida sem referência ao contexto social e cultural em que o indivíduo está inserido. Ele define o desenvolvimento cognitivo como sendo a conversão de relações sociais em fun-

ções mentais. É na socialização que a pessoa desenvolve os processos mentais superiores, sendo que a conversão das relações sociais em funções psicológicas ocorre na mediação. Vygotsky define uma área de interação social em que ocorre a aprendizagem como sendo a zona de desenvolvimento proximal. Segundo Moreira (1999), a zona de desenvolvimento proximal

[...]é a distância entre o nível de desenvolvimento cognitivo real e do indivíduo, tal qual sua capacidade de resolver problemas independentemente, e o seu nível de desenvolvimento potencial, tal como medido através da solução de problemas sob orientação ou em colaboração com companheiros mais capazes.

Portanto, a interação social que provoca a aprendizagem precisa ocorrer dentro da zona de desenvolvimento proximal.

Em sua busca de como são formados os conceitos, Vygotsky encontrou três fases básicas; subdividindo-as em estágios. Na primeira fase, a criança tende a agrupar objetos de maneira desorganizada, que incorpora fases de tentativa e erro. A segunda fase, considerada a mais importante, abrange muitas variações de um tipo de pensamento, denominado de pensamento por complexos, neste pensamento, os objetos se associam na mente da criança não somente devido às impressões subjetivas dela, mas também pela existência de ligação entre os objetos. A terceira fase, a de formação de conceitos, não necessariamente ocorre após o pensamento por complexos. Nesta fase ocorre a abstração, isolamento de elementos da experiência concreta (GASPAR, 1993).

Outro ponto levantado por Vygotsky é que a aprendizagem costuma ocorrer com uma forte interação entre os conceitos espontâneos/realistas ingênuos e científicos/culturais. Haveria um desenvolvimento dos conceitos realistas ingênuos em direção a conceitos mais abstratos e gerais, e ao mesmo tempo, o desenvolvimento de conceitos científicos em direção a conceitos mais concretos e particulares. 
As crianças mais jovens, segundo Piaget, apresentam concepções sobre o mundo e o universo do tipo realista ingênuo por possuírem uma visão egocêntrica. Ou seja, acreditam que o dia existe para o ser humano, a Lua e o Sol para iluminar e a noite para dormir. Esta concepção de que o mundo é feito para elas se perpetua até os seis ou sete anos, passando depois disto por formas em que as concepções são uma mistura entre o egocentrismo e a socialização do pensamento que ocorre por volta dos dez aos doze anos (BISCH, 1998).

Piaget também estudou a representação do espaço pela criança onde encontrou uma preocupação da criança com a vizinhança, ordem dos objetos e nem tanto com as proporções, escalas, ângulos e distâncias envolvidas. Outra dificuldade da criança é a mudança de referencial que exige a coordenação de diferentes pontos de vista, como por exemplo, preso à superfície terrestre, de onde observamos os astros, e o ponto de vista heliocêntrico (visto a partir do Sol) utilizado em praticamente todas as explicações dos fenômenos astronômicos ensinados no ensino fundamental, como estações do ano, fases da Lua, eclipses etc. O início desta capacidade de coordenar diferentes pontos de vista se inicia somente por volta dos 9 ou 10 anos (LEITE, 2002).

Em sua tese de doutorado Gaspar (1993) propõe que o referencial teórico de Vygotsky seja adotado em museus e centros de ciências. Compartilhamos com este autor a idéia de que os museus e centros de ciências são locais onde ocorrem as interações sócio culturais responsáveis pelo desenvolvimento cognitivo e aprendizagem. Isto permite que haja uma troca de conhecimentos em que a pessoa mais capacitada consegue dentro da zona de desenvolvimento proximal de uma pessoa menos capacitada ajudá-la na compreensão do assunto tratado. Sobre o ponto de vista de Vygotsky, o processo de aprendizagem de ciências ou de conceitos científicos é um processo cognitivo que não se completa numa visita a um centro de ciências.

A aprendizagem é um processo cumulativo derivado de muitas fontes que demanda tempo (FALK, 2001). Por exemplo, o conhecimento de uma pessoa a respeito de evolução estelar pode ser resultado do que leu numa revista de divulgação, visita a um observatório astronômico, palestra que assistiu sobre o assunto, e ainda comentários de professores. Todas estas experiências foram combinadas pela pessoa a fim de construir um entendi- 
mento pessoal de evolução estelar. Nenhuma destas fontes foi a única responsável por produzir o entendimento da pessoa sobre o assunto.

Segundo Falk e Storksdieck (2005) para compreendermos a aprendizagem em museus de ciências devemos deixar de lado a expectativa de que a aprendizagem siga necessariamente um curso prédeterminado e previsível. Em outras palavras, atividades e exibições bem planejadas podem facilitar a aprendizagem do visitante ao longo de um curso prédeterminado, mas os aprendizes precisam de uma ajuda para revelar a natureza e o caráter do que aprendem. Tipicamente o aprendizado em museus de ciências segue em geral dois caminhos paralelos segundo Falk e Storksdieck (2005): o aprendizado de idéias gerais; por exemplo, podem existir estrelas parecidas com o Sol que abrigam exo-planetas; e o aprendizado mais específico; por exemplo, o diâmetro solar corresponde ao diâmetro de aproximadamente 111 planetas Terra infileirados.

O aprendizado em sala de aula, em geral faz com que o aluno aprenda mais os aspectos específicos do conteúdo ensinado sem ser capaz de contextualizar o que aprendeu de maneira a tornar o conhecimento menos abstrato. Assim, os conteúdos passam a ser pouco valorizados pelos estudantes, fazendo com que eles os memorizem sem entender sua importância e logo após as provas acabam esquecendo-os (BRAUND; REISS, 2006).

No museu de ciências, em geral, os alunos aprendem melhor as idéias gerais e específicas, uma vez que as mesmas encontram-se contextualizadas, como por exemplo, o fato de o Sol ser bem maior que os planetas do Sistema Solar pode ser observada por uma maquete disposta no Campus I da USP de São Carlos, e assim não é somente um conhecimento vago de livros didáticos. O que o visitante aprende no museu de ciências não depende apenas do conteúdo, intenção da exposição e de atividades propostas. Cada pessoa irá aprender aspectos gerais e/ou específicos de acordo com seus conhecimentos prévios, experiências, interesses, diálogos realizados durante a visita, o que pensa a respeito da exposição e até mesmo o que ocorrerá depois que sair do museu de ciências que terá relação com sua experiência obtida dentro do museu (FALK; STORKSDIECK, 2005). 


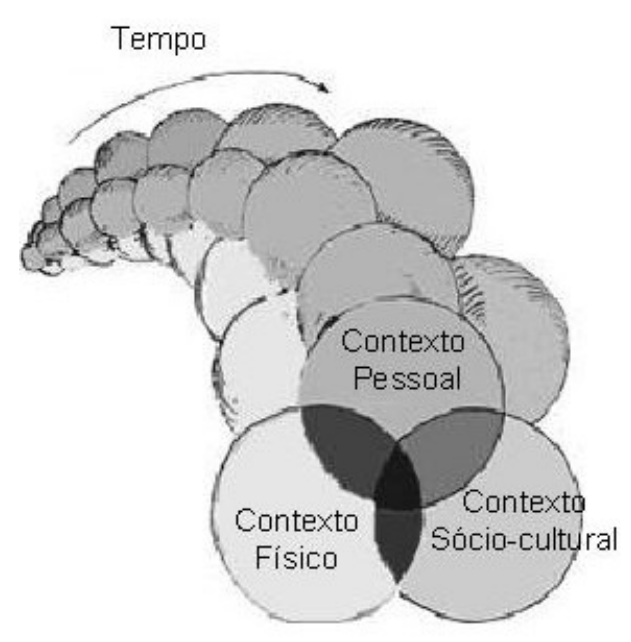

Figura 1 - Modelo da experiência interativa de aprendizagem (FALK; DIERKING, 1992) .

\subsubsection{O modelo contextual de aprendizagem}

Devido ao seu caráter complexo, muitos estudiosos de educação em museus de ciências têm buscado maneiras de avaliar a aprendizagem nestes espaços. Dentre eles, Falk e Dierking (1992) elaboraram o Modelo de Experiência Interativa que considera a aprendizagem sob a perspectiva dos visitantes considerando três contextos que influenciam na aprendizagem em museus de ciências; pessoal, físico e social (figura 1).

O contexto pessoal seria uma variedade de conhecimentos, experiências e interesses, crenças e motivações pessoais que são influenciadas pelas características do museu ou contexto físico. Ao chegar no museu, o visitante traz consigo uma série de expectativas e motivações que irão influenciar seu aprendizado dentro deste espaço. O contexto físico engloba as características do ambiente como arquitetura, qualidade da apresentação, iluminação e disposição do espaço e objetos contidos nas exposições. O comportamento do visitante é fortemente influenciado pelo contexto físico. Ao mesmo tempo, o contexto social também é importante, uma vez que ao caminhar por dentro das exposições há muitas vezes, diálogos entre os visitantes e com colaboradores do museu em busca de um sentido pessoal para o que estão vendo, ouvindo ou lendo.

Desta forma, os três contextos do Modelo de Experiência Interativa se combinam para promover uma experiência única ao visitante. Portanto, não há dois visitantes que vejam uma exposição da mesma forma, uma vez que num dado momento, cada contexto 
pode assumir um papel mais relevante para o visitante, a sua experiência é resultado das interações dos três contextos (FALK; DIERKING, 1992).

Posteriormente, estes mesmos autores acrescentaram ao modelo, a dimensão temporal. Ou seja, o fato de que recordações de experiências em museus que ocorreram anos atrás, mesmo que incompreensíveis podem contribuir para um aprendizado futuro. O modelo passou a ser chamado de Modelo Contextual de Aprendizagem, de Falk e Dierking (2000) onde sub-dividiram os três contextos em onze fatores. São estes:

\section{Contexto Pessoal:}

- Motivação e expectativas: Afeta diretamente o que uma pessoa faz e aprende em um visita; há aprendizagem quando suas expectativas são atendidas.

- Conhecimentos prévios e experiências: Desempenham um papel importante na aprendizagem, uma vez que toda aprendizagem é filtrada pela lente do conhecimento prévio e experiências. Fazendo com que a aprendizagem em museus de ciências seja altamente pessoal e única.

- Crenças e interesses prévios: Por meio destes é que a pessoa seleciona quando e o que deseja aprender, influenciando qual exibição será vista, o que vale a pena aprender, qual museu visitar etc. A grande diversidade de interesses dos visitantes contribui para que a experiência no museu seja pessoal e única.

- Escolha e controle: Os museus de ciências oferecem oportunidade de escolha e controle, uma vez que o indivíduo pode assistir, ler e ver o que mais lhe interessa, exercendo a aprendizagem por livre escolha.

- Eventos subseqüentes e experiências após a visita: A aprendizagem é um processo cumulativo. O público entra no museu com certos conhecimentos, sai com outros, estes conhecimentos passam a fazer sentido a partir do momento em que há acontecimentos na vida do indivíduo que facilitam e exigem tais conhecimentos. Portanto, as experiências e eventos que reforçam o que foi visto no museu são tão importantes para a aprendizagem quanto o que foi visto dentro do museu. 


\section{Contexto Físico:}

- Organizadores avançados: Estudos apontam que os visitantes aprendem mais sobre uma exibição no museu se tiverem informados a respeito da exposição anteriormente.

- Orientação no espaço físico: Estudos mostraram que a aprendizagem é reforçada quando as pessoas sabem se mover dentro de um espaço físico e, portanto, não se encontram desorientadas.

- Arquitetura e espaço físico: A temperatura, tamanho, população, novidades e até mesmo as cores do espaço podem influenciar a aprendizagem.

- Planejamento das exibições: As pessoas vão ao museu para verem objetos reais num meio rico em experiências educacionais. Exibições bem estruturadas são grandes ferramentas de aprendizagem.

\section{Contexto Sócio cultural:}

- Mediação dentro do grupo: Todos os grupos sociais nos museus podem interagir para decifrarem informações, reforçarem crenças, trazerem significado ao que está sendo visto, lido etc.

- Mediação facilitada por outros: Docentes, guias, monitores podem atrair, facilitar ou mesmo inibir a aprendizagem dos visitantes.

O Modelo Contextual de Aprendizagem é uma ferramenta importante para se investigar a aprendizagem em museus de ciências, uma vez que considera a interação de diferentes contextos que influenciam neste processo. Assim, julgamos importante investigar como os diferentes contextos interagem na aprendizagem dos temas Sol e física solar no Observatório do CDCC/USP, uma vez que a aprendizagem neste espaço é um processo pessoal, altamente dependente de experiências anteriores, ocorrendo num contexto sócio-cultural e envolvendo muitas fontes, experiências e informações que juntas são responsáveis pela construção do conhecimento. 
No próximo capítulo iremos conhecer um pouco sobre os equipamentos, técnicas adotadas nas observações do Sol e de seu espectro e o local onde as atividades foram realizadas, o Observatório Astronômico do CDCC/USP. 


\section{O Observatório Astronômico do CDCC/USP}

\subsection{Instalações}

O Observatório foi fundado em 1986, no campus da Universidade de São Paulo em São Carlos, por ocasião da passagem do cometa Halley, tendo como foco a divulgação de Astronomia. Sua criação foi uma iniciativa do, então, Instituto de Física e Química de São Carlos e da Coordenadoria de Divulgação Científica e Cultural (CDCC). O então, Instituto Astronômico e Geofísico da Universidade de São Paulo cedeu o Telescópio Refrator Grubb de montagem equatorial alemã para ser instalado em São Carlos. As instalações físicas iniciais do Observatório contaram com o apoio financeiro da USP, do CNPq e de indústrias de São Carlos (HÖNEL, 1996).

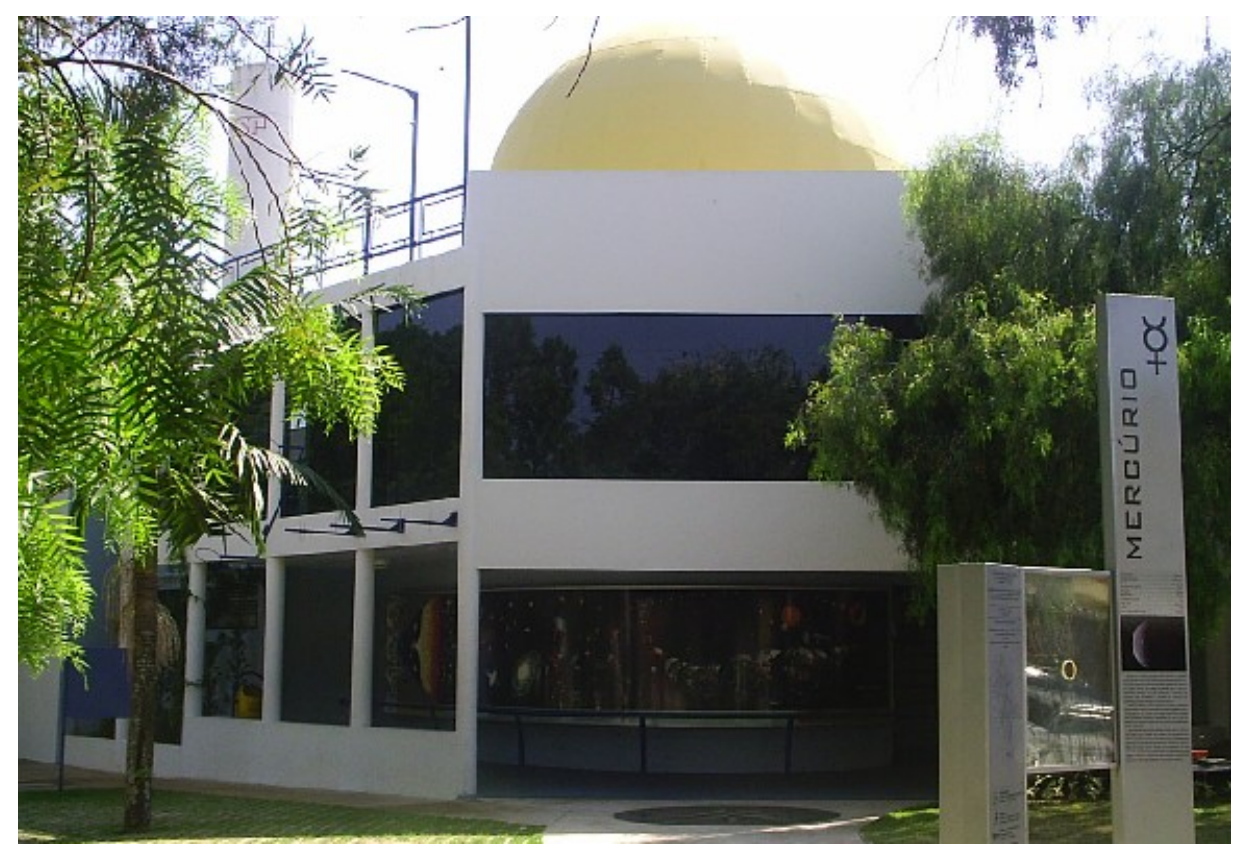

Figura 2 - Observatório Astronômico do CDCC/USP no Campus I de São Carlos .

O Observatório está localizado no Campus I da Universidade de São Carlos e possui instalações semelhantes a de um Observatório profissional. Uma foto da entrada do Observatório pode ser vista na figura 2. No primeiro andar, existe uma exposição de quadros contendo fotos e informações astronômicas, sendo que futuramente serão instaladas maquetes para explicar os eclipses e fases da Lua. No piso superior existe um almoxarifado 


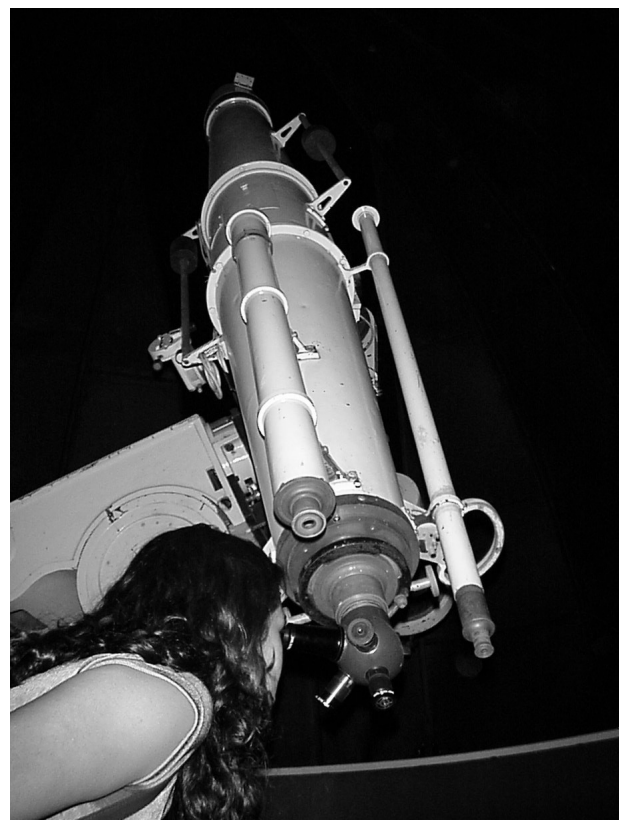

Figura 3 - O refrator Grubb.

com paredes de vidro, onde os equipamentos são guardados, de modo que é possível para os visitantes ver telescópios, globos (lunar, terrestre e marciano) e esferas celestes. Neste mesmo piso encontramos a sala solar que será descrita com mais detalhes na terceira seção deste capítulo. No terceiro piso está a cúpula do Observatório, onde está instalado o refrator principal, Grubb, com $204 \mathrm{~mm}$ de diâmetro e $3000 \mathrm{~mm}$ de distância focal (figura 3). Saindo pela porta da cúpula existe uma área externa de observação, onde são montados temporariamente outros telescópios.

Além disso, recentemente foi instalado no campus I de São Carlos, uma maquete em escala do Sistema Solar ocupando todo o campus. Esta maquete permite que uma pessoa andando pelo campus tenha uma idéia das proporções, tamanhos e distâncias entre os planetas. Além do Sistema Solar no campus, também existe uma esfera armilar para mostrar o movimento pendular do Sol ao longo do ano, dentre outras inovações para divulgação de Astronomia. Neste trabalho, iremos nos concentrar na sala solar onde grande parte do projeto foi desenvolvido. 


\subsection{Atividades educativas}

Apesar de o Observatório do CDCC/USP ser um observatório profissional em pequena escala, ele não é um observatório de pesquisa astronômica. Sua principal função consiste em atender à comunidade e região, à rede de ensino e aos alunos do curso de Licenciatura em Ciências Exatas da Universidade de São Paulo no campus de São Carlos. A localização do Observatório é propícia a receber visitas do público, uma vez que se situa na região central da cidade.

Durante a semana, no período matutino e vespertino, o Observatório recebe visitas de escolas da rede de ensino públicas e privadas. Nas atividades realizadas mostramos os principais telescópios, onde são feitas observações do Sol, Lua, Vênus e Júpiter quando os mesmos se encontram visíveis no horário de atendimento às classes.

O Sol é o objeto mais observado nas visitas diurnas, onde são ressaltados os cuidados necessários para observá-lo. Projetamos sua imagem em um anteparo para observarmos as manchas solares. Quando o céu encontra-se encoberto, mostramos as instalações do Observatório juntamente com imagens e vídeos educativos sobre o Sol e os planetas do Sistema Solar. No período noturno, temos alguns dias reservados ao atendimento de escolas, quando, os alunos podem observar além de planetas, estrelas duplas, nebulosas, estrelas e aglomerados.

O atendimento à comunidade da cidade e região é feito durante os finais de semana (de sexta à domingo) no período noturno das 20 às 22 horas, independentemente das condições atmosféricas. Durante tais visitas, o público pode conhecer as instalações do Observatório, observar planetas, estrelas, nebulosas, aglomerados e galáxias pelo telescópio principal e por outros telescópios colocados na área externa de observação. Aos sábados, os visitantes podem assistir a palestras de Astronomia ministradas pela equipe do Observatório, muitas das quais, encontram-se documentadas e disponíveis para acesso pela "homepage" do Observatório (HÖNEL, 1996).

O Observatório se preocupa também com os interessados em aprofundar seus conhecimentos em Astronomia, oferecendo para este público especial minicursos de diversos temas 
de Astronomia e Astronáutica com direito a certificados oferecidos pelo CDCC/USP. Tais cursos são voltados para públicos específicos como, por exemplo, professores da rede de ensino, adultos, alunos de graduação, crianças de primeira à quarta série, ensino médio dentre outros.

\subsection{A construção da sala solar e seus equipamentos}

A sala solar é uma sala inteiramente voltada para o estudo do Sol. Antes de existir, toda observação solar era realizada na cúpula e na área externa de observação. Este trabalho de pesquisa permitiu a inauguração da sala solar, com a construção de equipamentos, experimentos e atividades que foram realizados com alunos do ensino fundamental e médio.

Dentro da sala solar encontramos um telescópio que permite projetar o Sol com o dobro do tamanho da imagem do refrator Grubb, o que facilita a observação e desenho das manchas e fáculas presentes na fotosfera solar (figura 4). O telescópio da sala solar é do tipo newtoniano f/10 com $20 \mathrm{~cm}$ de abertura.

Em cima da sala solar existe um heliostato que consiste de um jogo de espelhos planos, sendo um deles motorizado que direciona a luz solar para outro fixo, que por sua vez, direciona a luz para dentro do telescópio que se encontra dentro da sala solar (figura 5). Esta disposição dos equipamentsos permite que o telescópio da sala solar seja fixo, ao contrário do refrator Grubb que necessita de um motor de acompanhamento.

O heliostato é composto por um espelho plano que acompanha o movimento do Sol por meio de um motor, direcionando a luz solar para outro espelho plano fixo no telescópio que, por sua vez, direciona a luz do espelho móvel para dentro do telescópio (figura 5). As dimensões dos espelhos usados foram ambos de $10 \mathrm{~cm}$ de diâmetro com uma planicidade de no mínimo $\lambda / 4^{2}$. A montagem eletrônica e mecânica do heliostato e do telescópio foram realizadas por Dario Pires, um hábil construtor de telescópios de Araraquara.

\footnotetext{
${ }^{2}$ É uma medida óptica que usa como princípio a interferência de anéis de Newton.
} 


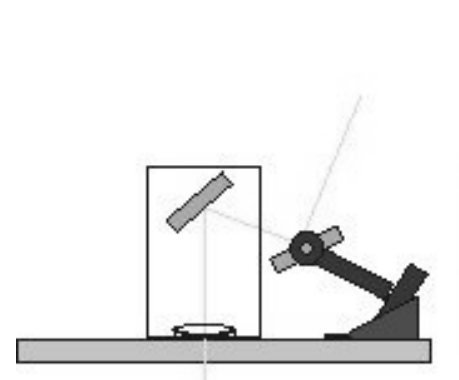

FIG. 1

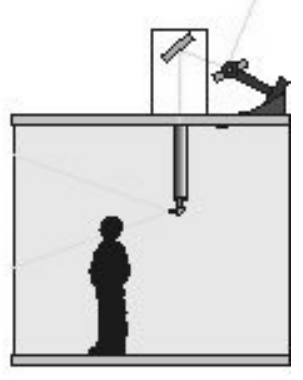

FIG. 2

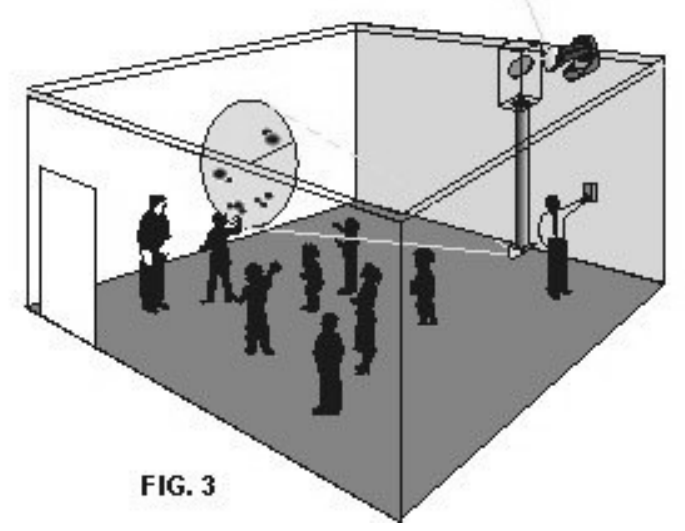

Figura 4 - Funcionamento da sala solar. Na Fig. 1 temos o esquema da parte de cima da sala solar mostrando a trajetória de raios de luz do Sol que atingem primeiro o espelho plano móvel, que direciona a luz para o espelho plano fixo, que por sua vez, atinge o telescópio que encontra-se na vertical. Na Fig. 2 temos um desenho da parte de dentro e de cima da sala solar mostrando o heliostato (jogo de 2 espelhos planos) e o Sol sendo projetado pelo telescópio. Por fim na Fig. 3 temos o desenho do interior da sala solar onde existem muitas pessoas observando a imagem de manchas solares no disco projetado na parede. Fonte: Fundação Planetário do Rio de Janeiro
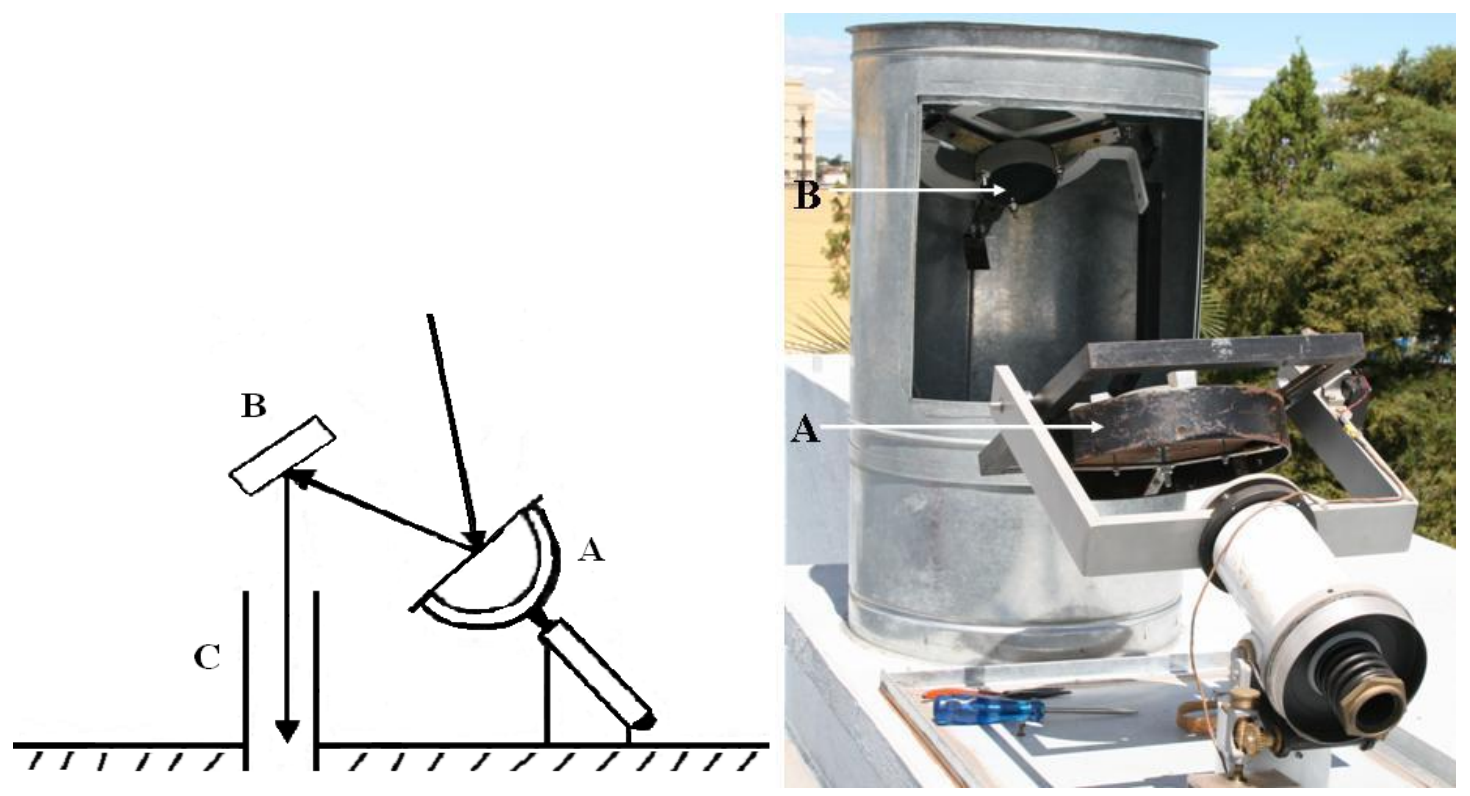

Figura 5 - Na figura da esquerda temos um esquema mostrando o funcionamento do heliostato, onde a letra $A$ indica o espelho móvel, a letra $B$ o espelho fixo e a letra $C$ o tubo do telescópio que se situa no interior da sala solar. Na figura da direita temos uma imagem do Heliostato do Observatório do CDCC/USP. 
Julgamos relevante descrever um pouco sobre as maneiras seguras de se observar o Sol, uma vez que as adotamos na sala solar. O Sol deve ser observado com extremo cuidado! Existem basicamente dois métodos de observá-lo, o de projeção e o de observação direta. Durante os minicursos usamos o método de projeção na sala solar e na cúpula do Observatório para observar a fotosfera do Sol e o método de observação direta com um filtro hidrogênio-alfa para observar a cromosfera solar. Maiores informações podem ser obtidas no livro de Nicolini (1985).

O método de projeção (figura 6) consiste em se apontar o telescópio usando a posição de mínima sombra projetada pelo telescópio (jamais olhando pelo telescópio!). Deve-se tomar extremo cuidado também, certificando que a buscadora (se houver) esteja devidamente tampada para não machucar o observador. Neste método deve-se ter uma ocular resistente ao calor do Sol (a maioria das oculares não o são!), como a que foi usada nos minicursos (quartzo fundido). Com este método foi possível observar manchas solares e fáculas.

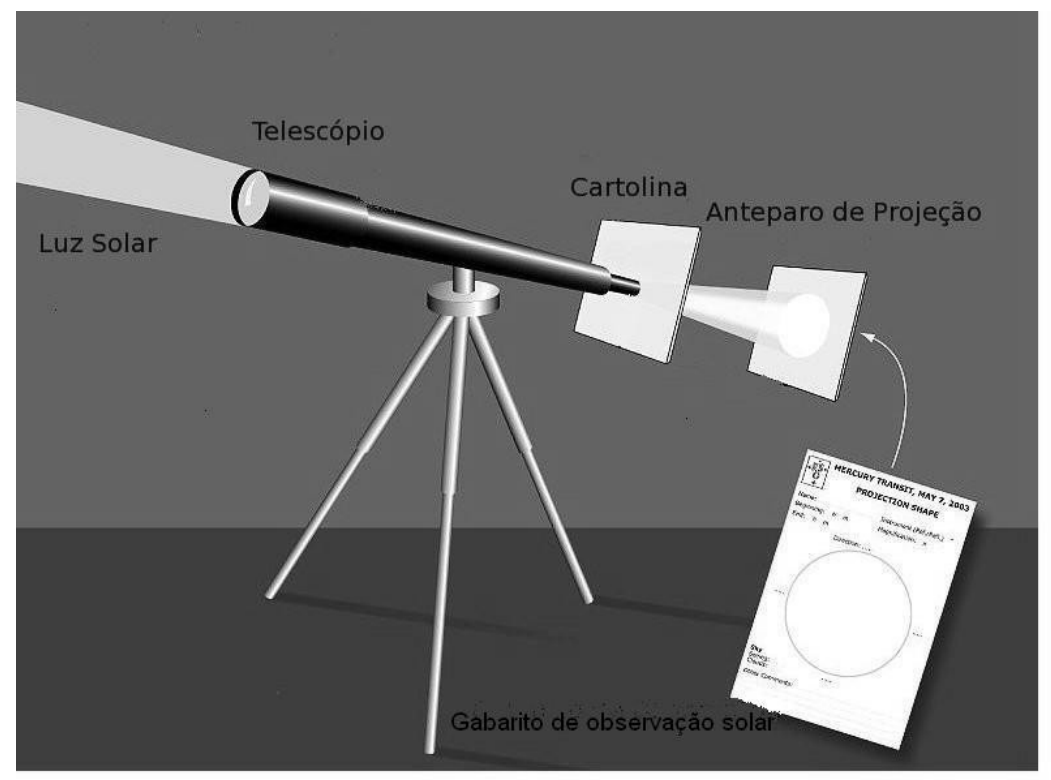

Figura 6 - Método de projeção solar e gabarito de observação solar. Figura do European Southern Observatories (ESO).

O método de observação direta da fotosfera necessita de um filtro confiável que permite passar 1/10 de milésimo da luz solar pela objetiva do telescópio, este filtro jamais deve ser usado na ocular, pois na ocular existe uma concentração maior de luz que pode danificá-la. Neste método pode-se olhar diretamente para o Sol pela ocular do telescópio. Novamente 


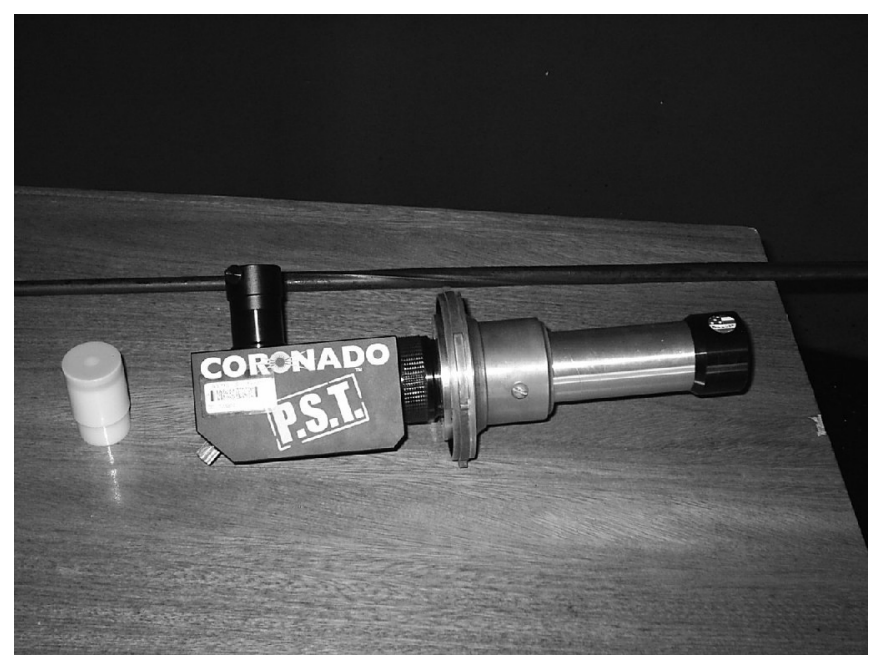

Figura 7 - O telescópio PST da CORONADO que possui um filtro hidrogênio-alfa

é necessário tampar a buscadora com um material confiável. No entanto, antes de olhar pelo telescópio é bom passar rapidamente a mão no feixe de luz que sai da ocular para ter certeza que o filtro solar está bloqueando boa parte da radiação solar.

O telescópio que foi usado para a observação direta da cromosfera foi o PST (Personal Solar Telescope da CORONADO, f/10 com 40mm de abertura com filtro hidrogênio-alfa) em conjunto com seu filtro especial (que permite a passagem somente numa estreita faixa em 656,3 nm que permite observar características da cromosfera solar como proeminências, espículas e flares (figura 7). Tais fenômenos não são possíveis de serem observados com um telescópio comum, uma vez que se encontram na cromosfera solar (a luz da fotosfera ofusca a cromosfera).

Para se obter um aumento maior acoplamos o telescópio PST da CORONADO ao telescópio refrator Grubb (figura 8). A montagem deste telescópio na Grubb foi possível graças a uma adaptação em que foi usada a distância focal do refrator Grubb, ao colocar uma lente divergente de $-2,5$ de dioptria (correspondente à distancia focal do PST/CORONADO) na objetiva do PST CORONADO e encaixá-lo dentro do refrator (removendo o jogo de oculares). Isto permitiu a observação de detalhes das proeminências. Outro equipamento que se encontra na sala solar é uma web cam Toucam Pro-II com uma câmera CCD que permite capturar imagens do Sol.

A sala está equipada também com um espectroscópio, especialmente construído para a observação das linhas do espectro solar (figura 9). Dentre estas linhas é possível observar 


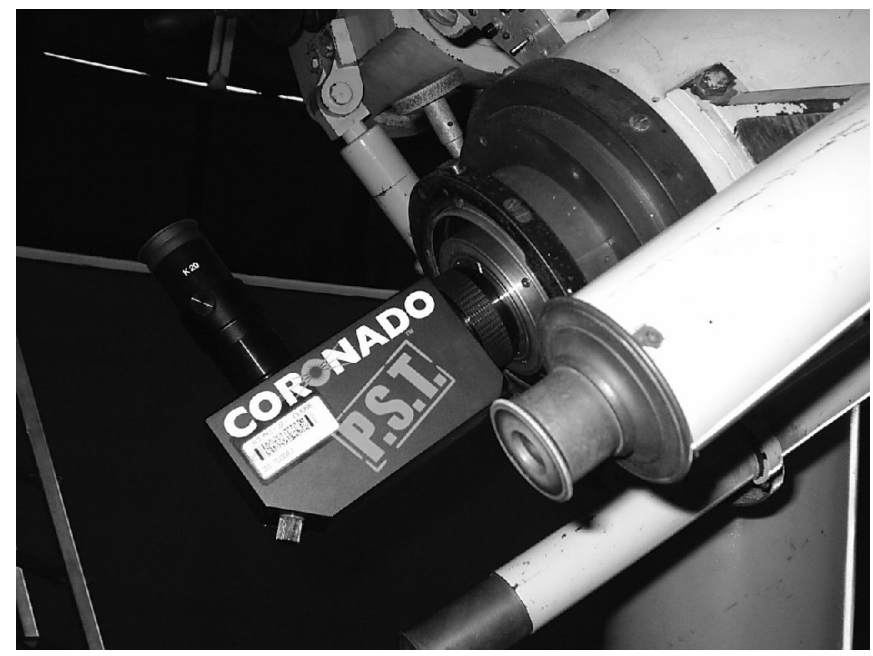

Figura 8 - O telescópio PST da CORONADO acoplado ao refrator Grubb .

bandas de oxigênio de nossa atmosfera e linhas de absorção do Sol.

Para uma melhor compreensão da natureza das linhas espectrais observadas, há também lâmpadas de gases que foram usadas juntamente com redes de difração, para se observar as linhas de emissão das lâmpadas e as comparar com linhas de absorção do espectro solar. Expostos nas paredes da sala existem quadros contendo as posições das linhas do espectro solar e de algumas lâmpadas, além disso há também, alguns quadros mostrando o Sol em diferentes comprimentos de onda.

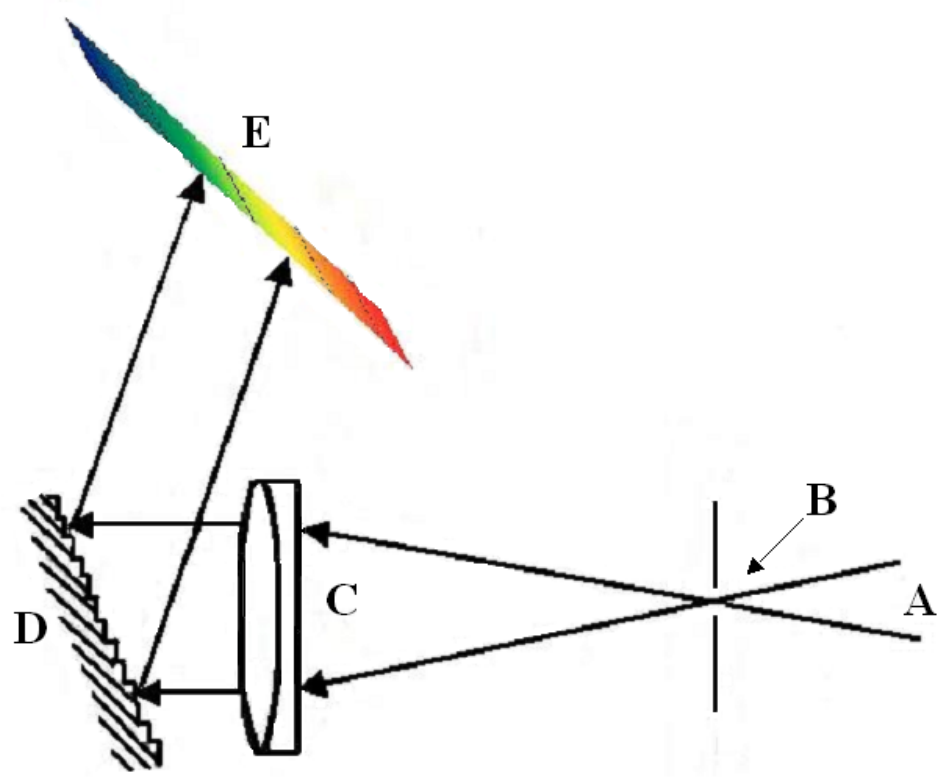

Figura 9 - Esquema do funcionamento do espectroscópio Littrow. A luz entra pelo telescópio $A$ passa pela fenda $B$, que atravessa então uma lente colimadora $C$ que direciona o feixe incidente em uma rede de difração por reflexão $D$, que reflete o espectro solar em um anteparo na altura da fenda $E$. 


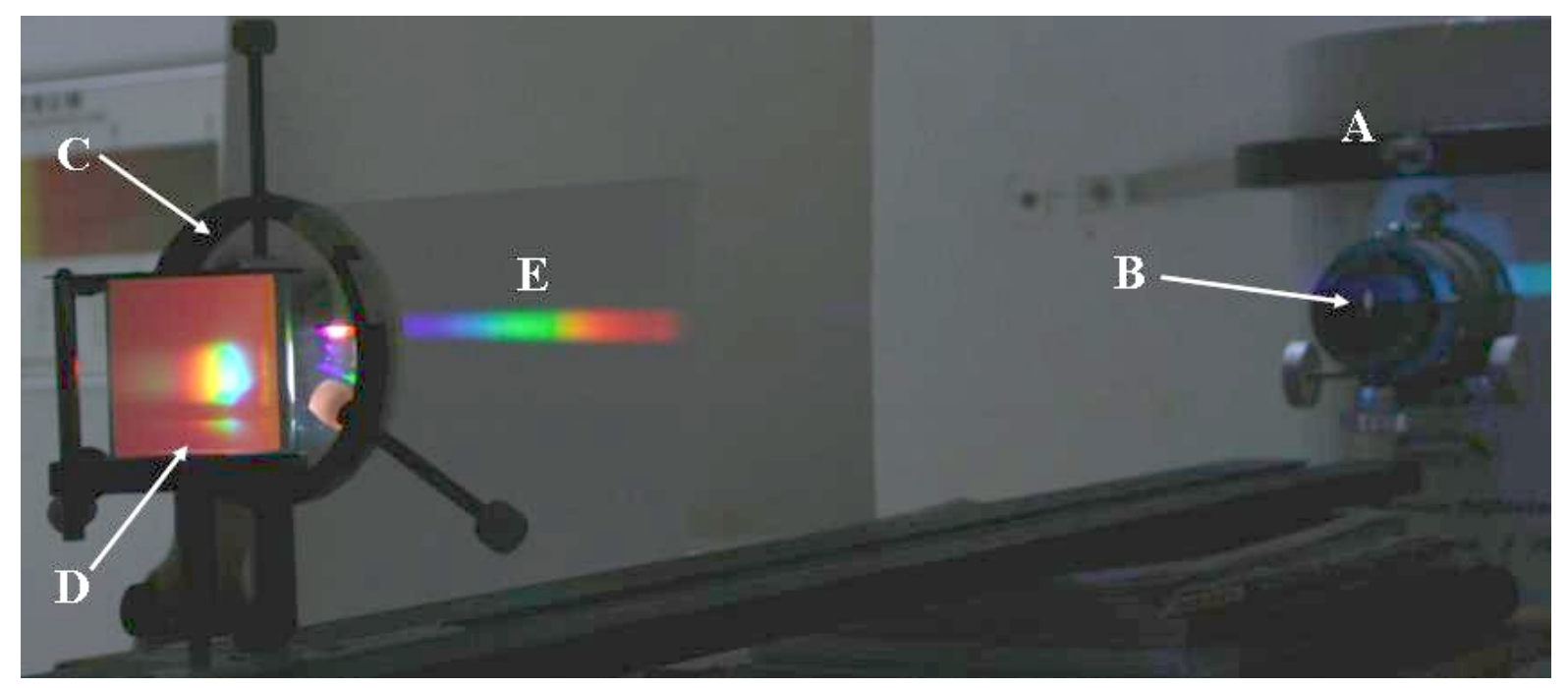

Figura 10 - Imagem do espectroscópio Littrow da sala solar. A luz entra pelo telescópio $A$ passa pela fenda $B$, que atravessa então uma lente colimadora $C$, que direciona o feixe incidente em uma rede de difração por reflexão $D$, que reflete o espectro solar em um anteparo na altura da fenda. E.

O espectroscópio foi montado de maneira a permitir que sejam vistos os principais componentes: fenda, lente colimadora e rede de difração. O heliostato e o telescópio foram usados juntamente com o espectroscópio para a obtenção do espectro do Sol. No lugar da ocular de projeção do telescópio foi colocada um fenda de $20 \mathrm{~mm}$ de comprimento e 0,2 $\mathrm{mm}$ de abertura, uma lente (dubleto acromático) com distância focal de $800 \mathrm{~mm}$ e 80 mm de diâmetro para colimar o feixe para dentro de uma rede de difração de reflexão de 1200 linhas/mm de 50x50 mm (figura 9). Com esta montagem denominada de Littrow foi obtido um espectro de aproximadamente $30 \mathrm{~cm}$ de comprimento (figura 10).

Conceitos básicos sobre nossa estrela vizinha e seu espectro encontram-se no apêndice A. Nos dois capítulos seguintes será discutido como estes conceitos e equipamentos foram explorados em um espaço não formal para alunos do ensino fundamental e médio por meio de um ensino interdisciplinar e questionador, analisando as influências dos contextos pessoal, físico e sócio-cultural de Falk e Dierking (2000) na aprendizagem dos temas Sol e seu espectro. 


\section{$5 \quad$ Física solar para o ensino fundamental}

Apresentamos, neste capítulo uma proposta de ensino sobre o Sol em um espaço não formal de educação para alunos do ensino fundamental. Aplicamos essa proposta por meio de minicursos denominados de Observando o Sol no Observatório Astronômico do CDCC/USP e avaliamos como as atividades sugeridas contribuíram no entendimento do tema "Sol" em diferentes séries do ensino fundamental.

\subsection{O contexto da proposta}

Diretrizes e tendências curriculares contemporâneos em todo o mundo enfatizam o papel desempenhado pelo contexto no ensino de ciências, uma vez que na visão do estudante, o contexto enriquece o aprendizado dos tópicos de ciências estudados (FALK, 2001). O ensino investigativo, também tem sido buscado no currículo escolar. No entanto, ensinar ciências apenas dentro da sala de aula não é suficiente para permitir aos estudantes uma visão contextualizada de ciências (BRAUND; REISS, 2006).

Na escola, a Astronomia é raramente ensinada por meio de atividades práticas, como a observação de planetas, do Sol, de estrelas e de seus movimentos, uma vez que os tópicos abordados são geralmente restritos às informações de livros didáticos. Tais assuntos deveriam ser abordados de maneira prática, uma vez que atraem os estudantes para a ciência contemporânea explorando tópicos que permitem um entendimento melhor a respeito da origem do Universo e do próprio homem.

Um dos papéis principais de museus e centros de ciências é o de motivar os estudantes para a ciência por oferecerem um ambiente atrativo permitindo a eles um contato direto com instrumentos e práticas científicas. Uma das maneiras de alcançar este objetivo é oferecer cursos permitindo, assim, que os visitantes de centros de ciências permaneçam por mais tempo dentro destas instituições. Decidimos desenvolver minicursos sobre o Sol por ser um tema pouco conhecido de professores e alunos das escolas que nos procuram. Acreditamos que esta seja uma realidade, também presente no restante do país. Explorar 
conceitos sobre o Sol permite penetramos em outros campos da ciência como a física e a química e desta forma promover um ensino interdisciplinar. Este panorama é fundamental para o estudante superar a visão compartimentada de ciências adquirida na escola.

\subsection{Os minicursos}

A proposta foi desenvolvida em quatro minicursos gratuitos, cada um com duração de 8 horas, ministrados ao longo de 2 semanas, consistindo de dois encontros semanais, voltados para alunos do ensino fundamental denominado de Observando o Sol nos anos de 2006 e 2007 no Observatório Astronômico do CDCC/USP. Os alunos que obtiveram pelo menos $75 \%$ de presença e que realizaram as atividades propostas tiveram direito a certificados.

A divulgação dos minicursos de 2006 foi feita com a colaboração de uma professora de ciências que ministrava aulas de quinta à oitava série em sua escola. A professora se prontificou a divulgar os minicursos em sala de aula após termos conversado com ela.

Já a divulgação dos minicursos de 2007 foi realizada pela própria autora que foi pessoalmente às escolas públicas e particulares expondo detalhes dos minicursos. Algumas escolas não deixaram que entrassem nas classes para fazer a divulgação, mas concordaram em fixar cartazes dos minicursos. Outro meio de divulgação foi a publicação dos minicursos no Boletim do CDCC/USP e no Boletim eletrônico Supernovas.

A princípio, foram ministrados cursos para alunos voluntários de quinta e sexta séries de uma escola particular do município de São Carlos no período da tarde de setembro a outubro de 2006 e outro curso, para alunos voluntários de sétima e oitava séries da mesma escola no mesmo período daquele ano. Em 2007, no mês de setembro repetimos os minicursos no período vespertino, mas desta vez para qualquer aluno voluntário interessado da rede de ensino. A tabela 1 mostra a distribuição de alunos e concluintes dos minicursos de 2006 e 2007, respectivamente. 


\subsection{Metodologia}

A metodologia adotada nos minicursos Observando o Sol de 2006 e 2007 foi a de diálogos expositivos envolvendo professora e alunos, incentivando a participação dos alunos por meio da realização de pequenos experimentos. Esta opção se justificou por compartilharmos a idéia de que "não é possivel observar como evolui a idéia de um aluno ao longo do processo de ensino, o que é possível descrever é a evolução das idéias como consequência da interação social com outros indivíduos" (MORTIMER, 2000). Além disso, o fato de o aluno expor seu pensamento sobre o assunto abordado, segundo Vygotsky, permite que ele possa organizá-lo de forma lógica (MOREIRA, 1999). Todos os dias, ao início das atividades, foram feitas revisões dos pontos mais importantes discutidos no dia anterior, escrevendo-os na lousa, com o objetivo de ajudar os alunos a pensarem mais sobre as atividades realizadas e fixarem seus conhecimentos sobre o Sol.

Considerando que é muito difícil avaliar quantitativamente a aprendizagem, ainda mais em um centro de ciências, optamos pela análise dos dados de maneira qualitativa, considerando o ambiente como fonte para coleta de dados, o pesquisador como principal instrumento e o processo, como o foco de interesse (LÜDKE; ANDRÉ, 1986). Com isto em mente, para levantar as concepções prévias dos alunos e avaliar as melhores formas de transpor os conteúdos astronômicos para a realidade de um centro de ciências, optamos pelo registro filmado dos minicursos e aplicação de questionários escritos no primeiro e último dia da realização dos minicursos. Por fim, elaboramos entrevistas semiestruturadas, compostas por questões abertas para complementar os resultados obtidos com o uso dos questionários escritos.

Como tarefa para casa, os alunos confeccionaram livros sobre o Sol, usando para isto material disponível na internet, revistas, livros e conteúdos do próprio mini-curso indicados

Tabela 1 - Relação de alunos dos minicursos de 2006 e 2007, respectivamente.

\begin{tabular}{|c|c|c|c|c||c|c|c|c|}
\hline Séries de 2006 e 2007 & $5 \mathrm{a}$. & $6 \mathrm{a}$. & $7 \mathrm{a}$. & $8 \mathrm{a}$. & $5 \mathrm{a}$. & $6 \mathrm{a}$. & $7 \mathrm{a}$. & $8 \mathrm{a}$. \\
\hline \hline Inscritos & 8 & 0 & 2 & 5 & 0 & 4 & 1 & 13 \\
\hline \hline Compareceram no primeiro dia & 8 & 0 & 2 & 5 & 0 & 4 & 1 & 11 \\
\hline \hline Concluíram o mini-curso & 5 & 0 & 2 & 3 & 0 & 4 & 1 & 8 \\
\hline
\end{tabular}


pela professora. O melhor livro sobre o Sol de cada mini-curso, recebeu como prêmio o livro "Nossa Estrela o Sol" de Adriana V.R. Silva (2006) com uma dedicatória especial da professora que ministrou os minicursos.

Os instrumentos usados (entrevistas e filmagem das aulas) apontam uma série de vantagens como a "captação imediata e corrente da informação desejada, aprofundamento de pontos levantados por outras técnicas como o questionário escrito, permitindo correções, esclarecimentos e adaptações que a tornam eficaz na obtenção das informações desejadas" (LÜDKE; ANDRÉ, 1986). Por fim, solicitamos que escrevessem suas avaliações pessoais sobre o mini-curso, respondendo a algumas perguntas sem que fosse necessário se identificar.

A primeira atividade dos minicursos foi a aplicação de um questionário escrito em que os alunos responderam às questões por meio de textos e desenhos, com o intuito de levantar suas idéias iniciais a respeito dos temas que seriam abordados. Em 2006, os questionários foram elaborados na forma de afirmações em que os alunos deveriam responder verdadeiro ou falso justificando a escolha feita. Ao analisarmos as respostas dos alunos a estes questionários notamos que muitos apenas escreveram $\mathrm{V}$ ou $\mathrm{F}$ sem justificativa de suas afirmações, além de termos notado uma certa confusão dos alunos ao lerem as afirmações do questionário. Os cursos de 2006 serviram como testes para melhor elaborarmos os cursos do ano seguinte, uma das mudanças foi a implementação de questões abertas nos questionários escritos dos minicursos de 2007 que encontram-se no apêndice C. Após realizarem os questionários escritos apresentamos um panorama geral do mini-curso.

As duas primeiras atividades, após a realização do questionário inicial foram estimar a distância e o tamanho do Sol em relação à Terra. Estas atividades proporcionaram uma noção do tamanho do Sol comparado à Terra e a outras estrelas, bem como as dimensões do Sistema Solar. O objetivo mais importante no primeiro dia do mini-curso foi explicar que o Sol deve ser observado com extremo cuidado. Para isto, foi mostrado que um papel sendo colocado no foco do telescópio queima em questões de segundos. Feito isto, foram discutidas as formas mais seguras de se observar o Sol com um telescópio e alguns tipos 
de telescópios existentes.

No final do primeiro dia do mini-curso foi debatida a natureza das manchas solares, após a observação das mesmas pelos alunos de 2006. A mesma discussão foi realizada com os alunos de 2007, porém com uma conotação um pouco distinta, interrogando-os sobre a inexistência de manchas no dia da observação, uma vez que não havia manchas no Sol na época em que o mini-curso foi desenvolvido.

A primeira etapa do segundo dia dos minicursos de 2006 e 2007 foi mais teórica na medida que era voltada para uma discussão de como o Sol produz e transporta sua energia. Foram discutidas duas analogias; a primeira envolvendo uma bomba de hidrogênio comparada à fusão nuclear que ocorre no interior do Sol e a última lidou com uma panela com água no fogo comparada à convecção existente nas camadas externas do Sol. Na segunda etapa deste dia, os alunos puderam manusear imãs e observar como os mesmos atraem e repelem uns aos outros, além de atraírem palhas de aço. Em seguida foram mostradas imagens de manchas solares com alta definição, que foram comparadas às configurações produzidas por imãs com o objetivo de associar o comportamento de manchas solares aos de ímãs.

O terceiro e o quarto dia dos minicursos de 2006 e 2007 foram mais focados no movimento das manchas solares buscando encontrar uma explicação para este comportamento. Esta atividade foi realizada a partir do terceiro dia, uma vez que os alunos já haviam observado o Sol e assim poderiam, apontar as diferenças entre o que foi observado de um dia para o outro. Outros pontos discutidos nestes dias foram a influência da atividade solar sobre a Terra e o significado de ciclo solar. Nestas atividades, os alunos confeccionaram gráficos com dados de uma tabela contendo a contagem de manchas solares em função do tempo para evidenciar o comportamento cíclico do número de manchas.

Uma novidade que foi acrescentada no mini-curso Observando o Sol de 2007 em relação ao de 2006 foi a inclusão de atividades de observação de "explosões solares" ou proeminências com o uso de um filtro especial. Mesmo com o Sol estando numa época de baixa atividade foi possível registrar a presença de proeminências e acompanhar suas mudanças. Com isto, os alunos aprenderam o quanto o Sol é dinâmico e que podemos 
observar diferentes fenômenos ocorrendo no Sol se "olharmos" em frequências específicas

No último dia do mini-curso, os alunos também observaram o espectro solar. Após a observação foi constatado que eles apresentaram bastante dificuldade de entender o que era o espectro e sua relação com o Sol; como isto já era esperado, o espectro foi exibido apenas com um efeito lúdico e intenção de despertar a curiosidade dos alunos sem esperar que eles fossem capazes de compreender completamente o que estava sendo observado, por isso o tema espectro solar foi explorado somente com os alunos do ensino médio. 


\subsection{Discussão dos resultados}

Optou-se por analisar os dados obtidos à luz do Modelo Contextual de Aprendizagem de Falk e Dierking (2000) por conter a interação de diferentes contextos responsáveis pela aprendizagem em museus de ciências. Assim, a análise não ficará restrita somente aos ganhos cognitivos dos alunos, após a realização dos minicursos, uma vez que este tipo de análise é bastante restrito quando se consideram os múltiplos fatores que podem influenciar a aprendizagem em museus de ciências, conforme discutido no capítulo 3 . A investigação de como os diferentes contextos interagem na aprendizagem do tema Sol e seu espectro no Observatório Astronômico do CDCC/USP é um processo pessoal, altamente dependente de experiências prévias, ocorrendo num contexto sócio-cultural e físico envolvendo muitas fontes, experiências e informações que juntas são responsáveis pela construção do conhecimento. Utilizamos também, conceitos das teorias de aprendizagem de Piaget e Vygotsky discutidos no capítulo 3, para a análise de alguns dos resultados obtidos.

\subsubsection{O Sol: seu tamanho e distância à Terra}

Conforme mencionado no capítulo 2, a revisão da literatura atual em ensino de Astronomia no Brasil e no mundo evidencia uma tendência dos alunos de apresentarem idéias confusas a respeito do Sol, da Lua e dos demais astros (BISCH, 1998; LEITE, 2002; SCARINCE; PACCA, 2006; ZIRBEL, 2004) Uma das possíveis estratégias para provocar uma mudança nestas idéias é confrontar os alunos com eventos discrepantes que contradizem seus próprios conceitos.

Segundo Piaget, as crianças mais jovens concebem um universo em que a ênfase está na vizinhança e na ordem dos astros, e não em suas proporções ou dimensões, escalas e ângulos (BISCH, 1998). Vários outro autores constataram isto (COLOMBO JÚNIOR; SILVA, 2007; LEITE, 2006; TRUMPER, 2001) em suas pesquisas conforme discutido no capítulo 2 .

Nossa pesquisa também constatou que os alunos desconheciam a ordem de grandeza 
da distância da Terra ao Sol e a das dimensões do Sol. Por exemplo, o aluno T. da quinta série de 2006 afirmou no questionário inicial (apêndice C), que o Sol não é a estrela mais próxima da Terra justificando "porque a[há] várias estrelas". Este aluno acredita que as estrelas estão próximas da Terra possivelmente até mesmo dentro do Sistema Solar.

Os demais alunos da quinta série de 2006, por sua vez, apresentaram respostas mais próximas às aceitas cientificamente no questionário inicial como o aluno M. da quinta série que escreveu, "porque vemos ela [Sol] maior que as outras estrelas.". Esta afirmação mostra que o aluno sabia que o Sol aparenta ser maior que as demais estrelas porque está mais próximo da Terra, apresentando uma certa noção de espacialidade.

O aluno L. da quinta série escreveu no questionário inicial :"sim porque depois do sol a estrela mais próxima está a alguns anos luz da terra." Este aluno já sabia que a medida que usamos fora do Sistema Solar é o ano luz e que a estrela mais próxima do Sol estaria a alguns anos luz, um conhecimento surpreendente para um aluno de quinta série.

O aluno Lu. da quinta série escreveu: "O Sol é a única estrela do sistema solar." Esta afirmação indica que o aluno sabia que o Sistema Solar possui somente uma estrela, o Sol e que portanto deveria ser a mais próxima da Terra. Todos alunos da sétima e oitava séries de 2006 e 2007 sabiam que o Sol é a estrela mais próxima da Terra.

Com a intenção de explorar o conceito de distância da Terra ao Sol, foi usada uma representação do Sistema Solar em escala dentro de um campo de futebol de COSTA (2006) (figura $11^{3}$ ) nos minicursos de 2006. Ao apresentá-lo foram discutidos o tamanho de um campo de futebol e as dimensões da pequena e da grande área. Em seguida, os alunos foram informados sobre a extensão do Sistema Solar em unidades astronômicas. A professora perguntou aos alunos qual a distância que a Terra está do Sol. Com uma regra de três envolvendo a distância da Terra (na metade da pequena área) ao Sol (no gol) e com os dados das dimensões de um campo de futebol real e no espaço foi possível responder à questão.

No ano seguinte, com a implementação do Sistema Solar em escala de tamanho e distância dentro do campus I da USP de São Carlos, a atividade descrita acima foi subs-

\footnotetext{
${ }^{3}$ Plutão a partir da Assembléia Geral da União Astronômica Internacional de 2006 não é mais classificado como planeta, mas sim como planeta anão. Ceres que se encontra na figura do campo de futebol, também passou a ser classificado como planeta anão.
} 


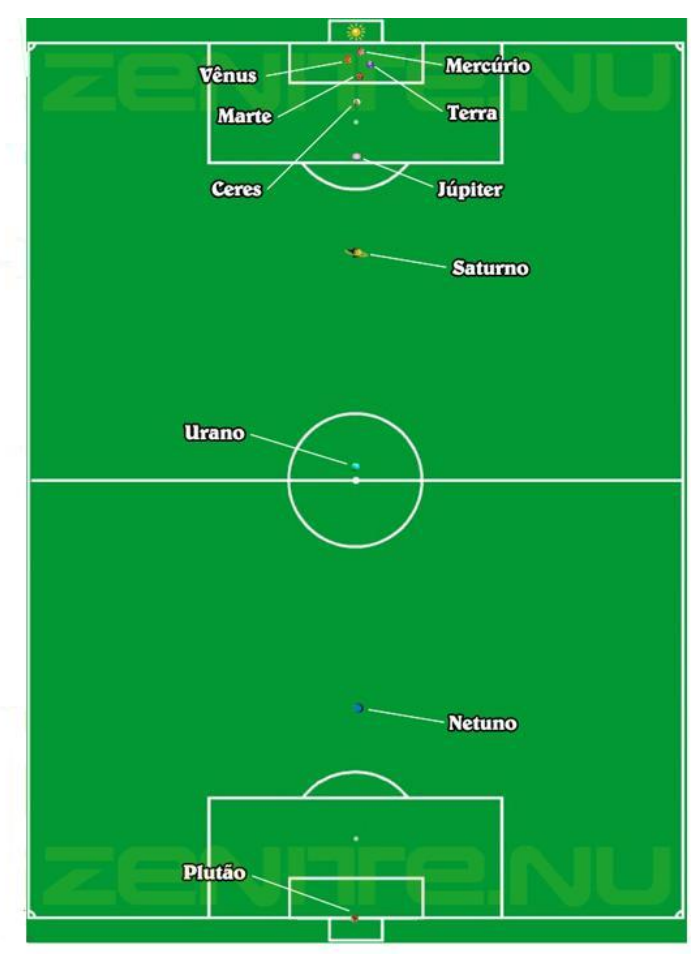

Figura 11 - Representação de um campo de futebol com o Sistema Solar disposto em escala de distância. Crédito: Costa (2006)

tituída por um passeio com os alunos pelos planetas e o Sol no campus de maneira que tivessem uma noção da separação entre os planetas e suas dimensões comparados ao Sol. Cada parada num planeta era seguida de uma explicação sobre sua temperatura, dimensão, número de satélites, distância até o Sol, sondas espaciais que o visitaram e algumas outras curiosidades do planeta.

Os alunos desconheciam a ordem de grandeza da distância da Terra ao Sol, um problema ocasionado possivelmente, por conhecimentos prévios do Contexto Pessoal (FALK; DIERKING, 2000) ao verem representações equivocadas do Sistema Solar em livros didáticos, levando-os a acreditar que o Sistema Solar possui outras estrelas, além do Sol. O conhecimento de que Sol aparenta ser maior do que as outras estrelas, porque se encontra mais próximo da Terra e ainda, que a estrela mais próxima da Terra depois do Sol está a alguns anos luz da Terra é provavelmente resultado de interesses prévios do Contexto Pessoal, já que estes conhecimentos são raramente explorados em sala de aula. No entanto, os 
aluno que participaram dos minicursos de 2006, tiveram uma professora que se preocupou em ensinar conteúdos de Astronomia em sala de aula, conforme nos informou os próprios alunos. Portanto, seus conhecimentos provavelmente foram influenciados, também por mediação desta professora. O aluno que havia escrito no questionário incial que o Sol não é a estrela mais próxima da Terra, após concluir o mini-curso afirmou que o Sol é a estrela mais próxima da Terra no questionário final e não mencionou "outras estrelas". Sua resposta final à questão foi provavelmente influenciada pelo Contexto Sócio-Cultural onde ocorreram discussões durante o curso sobre as dimensões do Sol comparadas aos da Terra e sua distância da Terra ao Sol.

A maior parte dos alunos de 2006 e 2007 sabia, antes mesmo de realizarem o mini-curso, que o Sol é maior do que a Terra sendo que alguns alunos forneceram dados quantitativos no questionário final.

Um caso curioso foi do aluno M7 da sexta série de 2007 que afirmou no questionário inicial que o Sol é a maior estrela da Via Láctea. Esta concepção provavelmente advém de achar que as estrelas no céu estão a aproximadamente a mesma distância que o Sol da Terra.

Apenas a aluna B6 de 2006 da sétima série, respondeu que "O Sol é menor do que a Terra, lógico, é uma estrela e é menor!!". Atualmente os alunos desde as séries iniciais têm informações de que a Terra gira em volta do Sol e de que Sol é uma estrela. A maior dificuldade deles está em conectar estes conceitos com o mundo em que vivem de forma a criar uma estrutura mental coerente para explicar os fenômenos observados (SCARINCE; PACCA, 2006). Citando o exemplo da aluna B6. da sétima série, ela sabia que o Sol é uma estrela, mas não conseguiu entender como que o Sol podia ser maior que a Terra sendo que as estrelas à noite aparecem como pontinhos luminosos. Foi verificado que faltou a noção do que são as estrelas, seus tamanhos comparados à Terra e a distância que se encontram comparadas ao Sol.

Com o objetivo de estimar quantas vezes o Sol é maior do que a Terra foi desenvolvida uma atividade com os alunos de 2006 e 2007 usando barbante e giz (para traçar uma circunferência), tesoura (para cortar o barbante) e botões de dois centímetros de diâmetro 
(representando a Terra). Os alunos traçaram uma circunferência de $220 \mathrm{~cm}$ de diâmetro, em seguida colocaram os botões ao longo do diâmetro solar (JONHSON; WAYMAN, 1997). Ao final da atividade contaram quantos botões foram dispostos atingindo valores próximos a 110 botões.

A concepção de que o Sol é a maior estrela da Via Láctea é baseada na observação sem a noção de espacialidade. Tal afirmação encaixa-se na categoria de experiências prévias do Contexto Pessoal. Já a concepção de que o Sol é menor do que a Terra por ser uma estrela mostrou que a aluna buscou uma solução particular para o fenômeno que tentava explicar, baseada na observação do Sol e das estrelas noturnas (experiências prévias do Contexto Pessoal) combinado com seu conhecimento prévio do Contexto Pessoal de que o Sol é uma estrela.

A aluna, que havia escrito no questionário inicial que o Sol é menor do que a Terra, escreveu no questionário final, "o Sol é muito maior do que a Terra". O desenvolvimento da atividade de se estimar o tamanho do Sol comparado à Terra, ou seja o Contexto Físico e da discussão sobre a existência de estrelas maiores e menores que o Sol, o Contexto SócioCultural permitiram que a aluna adquirisse uma noção do tamanho do Sol comparado às estrelas e à Terra. Os contextos Físico e Sócio-Cultural também influenciaram na resposta do aluno que escreveu no questionário final que o Sol é cerca de 110 vezes maior do que a Terra, não apresentando a concepção inicial de que o Sol seria a maior estrela da Galáxia.

Analisando as respostas aos questionários iniciais notamos que os alunos apresentaram concepções ingênuas misturadas com conceitos mais próximos aos aceitos pela comunidade científica, o que é natural para este nível de escolaridade. Tais fontes de pré-concepções foram bastante diversificadas. Constatamos que o Contexto Pessoal que considera a motivação, experiências e conhecimentos prévios tenha sido o principal fator de influência sobre as respostas dos alunos ao questionário inicial. Já as respostas ao questionário final, foram influenciadas não apenas pelo Contexto Pessoal, mas também pelo Contexto Sócio-Cultural e Físico com a vivência do mini-curso no Observatório. 


\subsubsection{Telescópios e cuidados ao se observar o Sol}

A principal ferramenta do mini-curso de 2006 foi o telescópio refrator Grubb e, em 2007, o telescópio newtoniano da sala solar. Ambos foram importantes por permitirem a observação de manchas solares, por isso foi necessário discutir um pouco de como o telescópio funciona. As atividades desenvolvidas durante os minicursos tiveram o intuito de apenas introduzir o telescópio mostrar que é construído por um tubo que sustenta lentes e às vezes até espelhos. Além disto, um telescópio possui sistemas para acoplagem de oculares e sistemas para acompanhar o movimento dos astros, bem como para localizálos. Foram discutidas as principais funções de um telescópio que são: apontar para objetos no céu; coletar a luz de objetos fracos produzindo imagens brilhantes; aumentar o tamanho da imagem do objeto sendo observado e permitir observar detalhes das imagens.

$\mathrm{Na}$ forma de um diálogo expositivo foi perguntado aos alunos por onde a luz do Sol entra no telescópio, qual o caminho que esta percorre lá dentro e por qual parte do telescópio a luz sai. Os alunos chegaram à conclusão que é por meio da lente objetiva que a luz entra passando por dentro do tubo oco e convergindo para a ocular.

Outro ponto que foi discutido foi à necessidade ou não de espelhos num telescópio. Todos alunos de 2006 no questionário inicial responderam que um telescópio necessita de espelhos. Um aluno de oitava série de 2006 justificou o uso de espelhos em um telescópio ao afirmar "sim, pois é necessário o espelho para formar a imagem". Outro colega da mesma série de 2006 respondeu; "sim, pois, seu sistema de aproximação se baseia em espelhos".

Uma aluna de sétima série de 2006 que havia respondido verdadeiro para a questão justificando que os espelhos dos telescópios servem para refletir a luz, respondeu no questionário final, que os mesmos serviam para direcionar a luz e as lentes, para aproximar o objeto observado. A aluna parece ter entendido a finalidade dos espelhos e lentes dos telescópios provavelmente compreendendo que um telescópio pode não ser composto apenas por espelhos. Os demais alunos (2006 e 2007) no questionário final afirmaram, que o telescópio do Observatório tem apenas lentes, alguns destes alunos haviam respondido no 
questionário inicial que todos os telescópios têm espelhos.

Todos alunos de 2006 responderam no questionário inicial, que os telescópios diferem entre si mencionando que não é apenas o tamanho o fator que os diferencia. Um aluno de oitava série de 2006 escreveu no questionário inicial que alguns têm mais "potência mais alcance de visão". Uma aluna de sétima série de 2006 escreveu no questionário inicial "a qualidade e quantidade de lentes varia". Ela não mencionou que o modelo ou a disposição óptica do telescópio podia variar. Outro aluno de oitava série de 2006 foi mais geral ao escrever que não só o número de lentes varia, como também os sistemas usados, porém ele não definiu o que seriam estes sistemas.

No curso seguinte, os alunos puderam conhecer, além do refrator principal outros telescópios. Apontamos um telescópio refrator para a antena de um prédio. Os alunos ficaram surpresos ao constatarem que a mesma encontrava-se de cabeça para baixo. Explicamos que isto é devido à presença de lentes que compõem a luneta, sendo o sistema óptico mais simples para observar objetos longínquos e que na Astronomia não temos uma referência para saber se o objeto no céu encontra-se ou não de cabeça para baixo. Além disso, mostramos outros tipos de telescópios como um dobsoniano composto por espelhos e discutimos o caminho percorrido pela luz em cada um dos telescópios.

Durante os minicursos para que os alunos ficassem sensibilizados quanto ao perigo que a observação solar descuidada representa, foi colocada uma folha de papel no foco do telescópio que estava apontado para o Sol. Em questão de segundos viram o papel queimar. Após uma euforia geral, foram discutidos os métodos existentes de observação solar, o método direto (com filtros na objetiva, jamais na ocular!) e o de projeção (COSTA; CALBO; OLIVEIRA, 1995). Como explicado no capítulo anterior, foi feita a opção de trabalhar com a projeção do Sol por ser mais seguro e permitir que muitas pessoas possam ver o Sol ao mesmo tempo (figura 6 do capítulo 4).

Todos alunos sabiam que o Sol pode representar um perigo ao ser observado por um telescópio, uma vez que, no questionário inicial colocaram que o Sol pode danificar ou mesmo queimar a visão.

Apenas um aluno da oitava série de 2006, apresentou no questionário final uma con- 
cepção equivocada de que se necessita sempre de um filtro especial no telescópio para observar o Sol por projeção. O aluno parece ter se esquecido da projeção solar, apesar de ter sido a técnica adotada no mini-curso. Talvez ele tenha pensado que mesmo na projeção necessita-se de um filtro para não danificar a óptica do telescópio, o que não é verdade.

Durante a discussão sobre métodos de observação solar foi perguntado aos alunos porque é necessário o uso de filtros solares sobre a pele quando se está exposto ao Sol. Os alunos responderam que é pelo fato do Sol emitir ultravioleta e calor.

Em seguida, foi discutido o papel desempenhado pela atmosfera terrestre ao barrar grande parte da radiação ultravioleta. Os alunos desconheciam a existência de outras freqüências de radiações além da ultravioleta, luz (para eles representava apenas o visível) e calor. Foi uma surpresa para os alunos saberem que o Sol, por ser uma estrela, deveria emitir em muitas outras radiações, como por exemplo, raios X e microondas.

Os alunos de sétima e oitava séries de 2006 sabiam que o ultravioleta e o microondas são ondas invisíveis, como pode ser constatado no diálogo abaixo.

Prof: Vamos ver o Sol. Como que a gente se protege do Sol?

Aluna N. da sétima série: protetor solar

Prof: O que tem no protetor solar?

Aluna N. da sétima série: filtro $U . V$.

Prof: $O$ que quer dizer filtro U.V.?

Aluna N. da sétima série: ultravioleta

Prof: Certo, a gente consegue enxergar no U.V. ?

Aluna N. da sétima série: não

Prof: Por que não?

Aluna N. da sétima série: É uma onda, não é?

Prof: E daí, nós conseguimos enxergar as ondas da água.

Aluna N. da sétima série: quando a gente liga o microondas solta ondas, mas a gente não vê.

Prof: Por que que a gente não vê ultravioleta e nem microondas? 
Aluno J.E. da oitava série: não são visíveis

Prof: Por que não?

Aluno J.E. da oitava série: não é matéria

Foi discutido com os alunos que não é possível enxergar as tais ondas invisíveis porque a atmosfera barra boa parte da radiação que não seja uma porção do infravermelho e o visível. Os olhos humanos e de outros animais provavelmente sofreram uma adaptação ao longo da escala evolutiva de forma que fosse possível ver apenas a radiação que nos seria útil à sobrevivência como o visível. O infravermelho e ultravioleta também são radiações úteis para a sobrevivência de outros animais como, por exemplo, cobras que são capazes de detectar o infravermelho e alguns pássaros que enxergam no ultravioleta. Os olhos humanos são compostos principalmente por água, que absorve muito no visível, mas não absorve em outras radiações como os raios X e ultravioleta. Portanto, vemos uma região muito estreita do espectro emitido pelo Sol por uma limitação imposta pela atmosfera terrestre e a evolução de nossos próprios olhos.

Os alunos que responderam que um telescópio precisa ter espelhos foram provavelmente influenciadas por imagens de grandes telescópios divulgados pela mídia. De fato, os maiores telescópios do mundo são compostos por espelhos. Portanto, os conhecimentos prévios do Contexto Pessoal, provavelmente tiveram uma influência determinante na resposta destes dois alunos. Nenhum aluno respondeu no questionário final que um telescópio necessita de espelhos, suas respostas foram influenciadas pelo Contexto Físico, uma vez que viram o telescópio principal do Observatório que não possui espelhos e pelo Contexto Sócio-Cultural, pois houve uma discussão envolvendo o grupo de alunos e a professora sobre os componentes do telescópio.

Os alunos sabiam que o Sol emite calor porque ele é capaz de queimar muitas coisas, baseado em suas experiências prévias do Contexto Pessoal. Aprenderam na escola que o Sol emite ultravioleta, ou mesmo pela mídia, durante um comercial de televisão anunciando um protetor solar, ou seja, sofreram também influência de conhecimentos prévios do Contexto Pessoal e do Contexto Sócio-Cultural. Por fim, as discussões realizadas com os alunos, o Contexto Sócio-Cultural, permitiram que compreendessem que o Sol emite 
em todas as frequências e que analisando-o em determinados comprimentos de onda é possível estudá-lo em diferentes profundidades (ver apêndice A). 


\subsubsection{A constituição do Sol}

Nos questionários iniciais de 2007 foi perguntado como o Sol produz energia. Uma resposta curiosa foi a de um aluno de oitava série, R7. do mini-curso de 2007 que afirmou que o Sol produz sua energia com a ajuda de outras estrelas. Esta resposta nos surpreendeu, uma vez que não encontramos nada parecido na literatura. Os demais alunos de 2006 e 2007 afirmaram que o Sol produz energia por explosões ou que libera gases que explodem. No entanto, os alunos não definem se estas explosões ocorrem no núcleo ou na superfície solar.

A discussão sobre o interior do Sol foi iniciada com a pergunta: "Como que vocês acham que é o interior do Sol?" Os alunos de quinta e sexta série de 2006 responderam que é quente. Para entender como eles concebiam o interior do Sol foi perguntado sobre seu estado físico. Alguns alunos responderam que o núcleo do Sol é sólido composto por lava e outros disseram que é líquido. Estas concepções são reflexo de conhecimentos prévios que os alunos possuem sobre o interior da Terra que aprenderam em sala de aula e de experiências prévias deste mesmo contexto, que aprenderam ao estudarem fenômenos geológicos.

Outra pergunta feita durante a discussão relativa ao interior do Sol foi: "Como o Sol libera tanta energia?" Os alunos responderam que seria devido às colisões entre os átomos, uma vez que era isto que estava sendo discutido, pouco antes de a pergunta ser feita. Foi explicado que este processo de colisão entre os átomos no interior do Sol gera a fusão nuclear. Para que os alunos obtivessem uma idéia quantitativa da energia liberada pelo Sol foi feita uma comparação entre o valor de energia liberada por uma bomba atômica e o valor de energia liberada pelo Sol. Para isto, foi necessária uma regra de três simples em que dividiram a quantidade de energia liberada pelo Sol, por segundo, pela quantidade de energia liberada por uma única bomba atômica, chegando ao resultado de que é preciso cem bilhões de bombas atômicas explodindo de uma única vez para igualar à quantidade de energia liberada pelo Sol em um segundo. Ao obterem estes resultados, os alunos ficaram fascinados com a potência do Sol. 
A maior parte dos alunos conhecia a composição do Sol (hidrogênio e hélio), e foram informados pela professora, que o Sol transforma hidrogênio em hélio pela fusão nuclear. Sabiam também, que o hidrogênio e o hélio são gases na Terra. Com exceção de um aluno de oitava série de 2006 que afirmou no questionário inicial que o Sol produz energia por combustão. Conforme foi explicado no apêndice A .1, a combustão era uma hipótese aceita para a produção de energia no Sol até o século XVIII, quando foi descoberto que o Sol não poderia produzir energia desta forma, pois teria sido extinto em dez mil anos. Hoje se sabe, por evidências geológicas, que o Sol possui aproximadamente 4,5 bilhões de anos.

Os alunos que já sabiam a composição do Sol, provavelmente aprenderam isto na escola, já que a professora ensinou conteúdos de Astronomia, portanto seus conhecimentos prévios sofreram influência do Contexto Sócio-Cultural. Já o aluno que assumiu que a produção de energia no Sol ocorreria da mesma maneira que uma das principais fontes de energia na Terra, a combustão, usou suas experiências prévias do Contexto Pessoal para explicar a energia solar. Já sua resposta à mesma pergunta no questionário final foi provavelmente influenciada pela discussão sobre a produção de energia solar durante o curso. Como pode ser constatado por sua resposta, em que escreveu que a produção de energia ocorre no Sol devido à transformação de gases. A transformação de gases, mencionada pelo aluno, provavelmente se refere à fusão nuclear do hidrogênio em hélio discutida durante o mini-curso, ou seja sua resposta final teve influência também do Contexto Sócio-Cultural.

\subsubsection{Representações do Sol}

Segundo Bisch, as concepções dos alunos de primeira à quarta série a respeito do Sol são as de disco, esfera, cor amarela e com destaque especial às representações de "raios solares". Numa concepção realista ingênua do Sol, a cor amarela e, sobretudo, os "raios solares", parecem ser muito mais importantes que a forma (disco ou esfera) para crianças de primeira à sexta séries (BISCH, 1998).

Os resultados da pesquisa realizada com os alunos dos minicursos Observando o Sol, no entanto, indicou um predomínio da primeira concepção, a de disco ou esfera onde os 


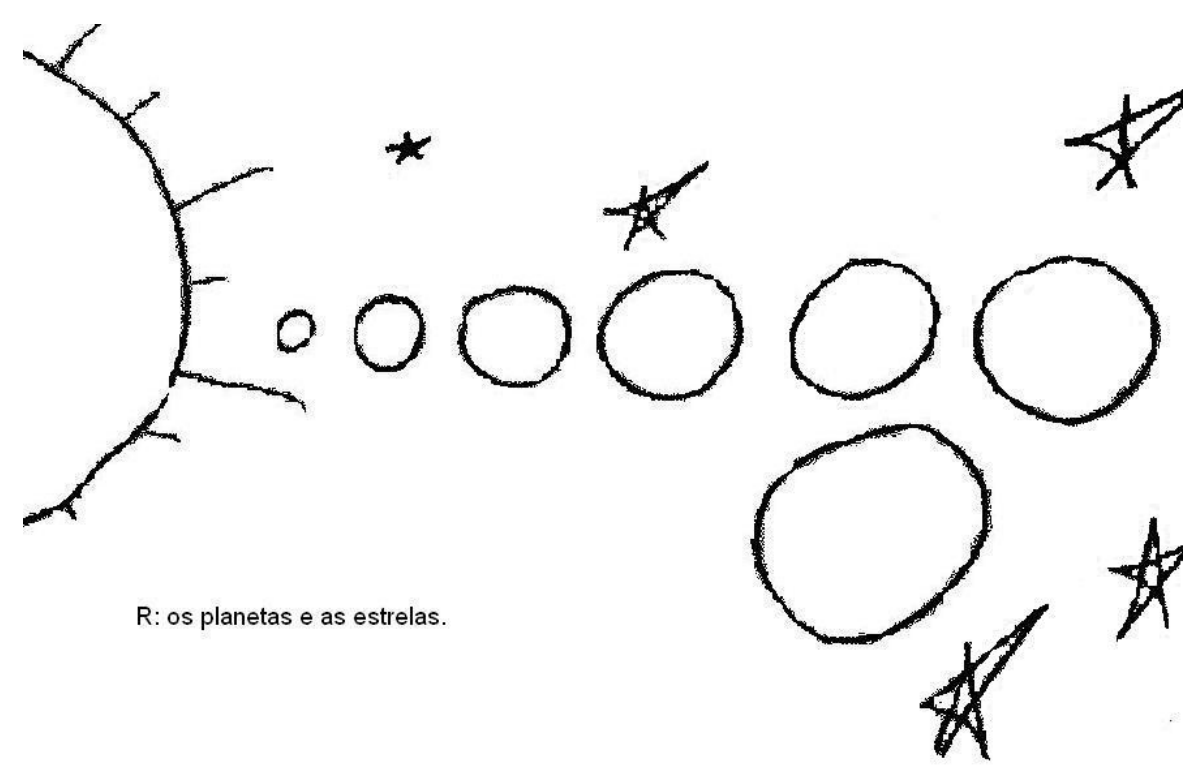

Figura 12 - Representação solar de um aluno de quinta série.

alunos também usaram palavras como quente e brilhante. Isto se deve provavelmente ao fato, de os alunos de nossa amostra pertencerem a séries mais avançadas que os analisados por Bisch (1998).

Uma constatação interessante ocorreu no questionário inicial de um aluno de quinta série que participou do mini-curso de 2006. Ele desenhou, o disco solar colocando juntamente com o Sol, o restante do Sistema Solar e estrelas. Isto talvez resulte do fato de o aluno achar, que o Sol, os planetas e as estrelas estão muito próximos entre si (figura 12). Este último resultado foi semelhante aos obtidos por Bisch ao analisar as concepções prévias de professores do ensino fundamental de escolas públicas em São Paulo (BISCH, 1998). Este autor notou que esta representação espacial do Sistema Solar, com o Sol e os demais planetas próximos entre si, reflete o esquema equivocado dos livros didáticos que explica as estações do ano de acordo com o periélio e afélio da órbita da Terra. Alguns livros didáticos inclusive apresentam um Sistema Solar com pontinhos em volta que representam estrelas confundindo o professor e os alunos (LEITE; HOSOUME, 2005). Tal concepção não foi observada nos questionários escritos dos alunos de 2007.

Outro aluno de quinta série de 2006, G6. desenhou, no questionário inicial, um Sol com manchas e arcos e ainda especificou que tais arcos são de hidrogênio em seu desenho (figura 13). O aluno provavelmente representou o Sol desta forma, por ter visto imagens 


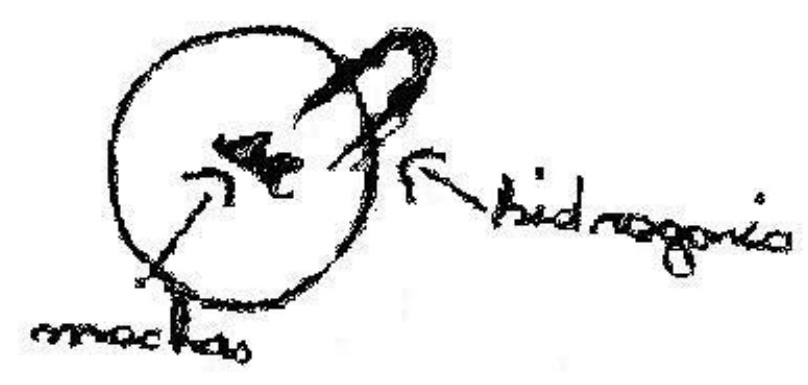

Figura 13 - Representação solar de um aluno de quinta série.

do Sol obtidas por satélites, ou com o uso de filtros especiais que permitem observar os tais arcos de hidrogênio, o que não é possível com um telescópio comum.

Muitos alunos de quinta à oitava séries que participaram dos minicursos de 2007 representaram o Sol com manchas, arcos e raios. No caso destes alunos, como houve uma divulgação em sala de aula antes da realização dos minicursos pela autora, já esperavam observar explosões e manchas solares, uma vez que usamos estes termos como chamariz para que os alunos tivessem interesse em fazer o mini-curso.

Uma aluna da sétima série de 2006 escreveu no questionário inicial que esperava observar as explosões do Sol, o que indica, um conhecimento adicional, aceito cientificamente, sobre o Sol, porém que não é possível ser observado por um telescópio sem o uso de filtros especiais.

Uma das representações do Sol mais interessantes foi a de um aluno de sétima série, G7. de 2007 que pode ser vista na figura 14. No desenho de G7. podemos notar que as explosões são maiores que o próprio Sol, uma concepção interessante, uma vez que muitos livros de Astronomia e "sites" na internet explicam que a camada mais externa do Sol, a coroa solar, se estende por todo o Sistema Solar, o que o aluno não sabia é que não iríamos observar a coroa solar (figura 34 do apêndice A), apenas alguns detalhes da cromosfera.

Outro aluno, B6. da quinta série de 2006 descreveu o Sol como sendo uma esfera amarela com muitos "gêiseres" e escreveu que sua cor varia de laranja ao amarelo. É interessante notar que o aluno não escreveu disco e sim esfera apresentando assim, uma 


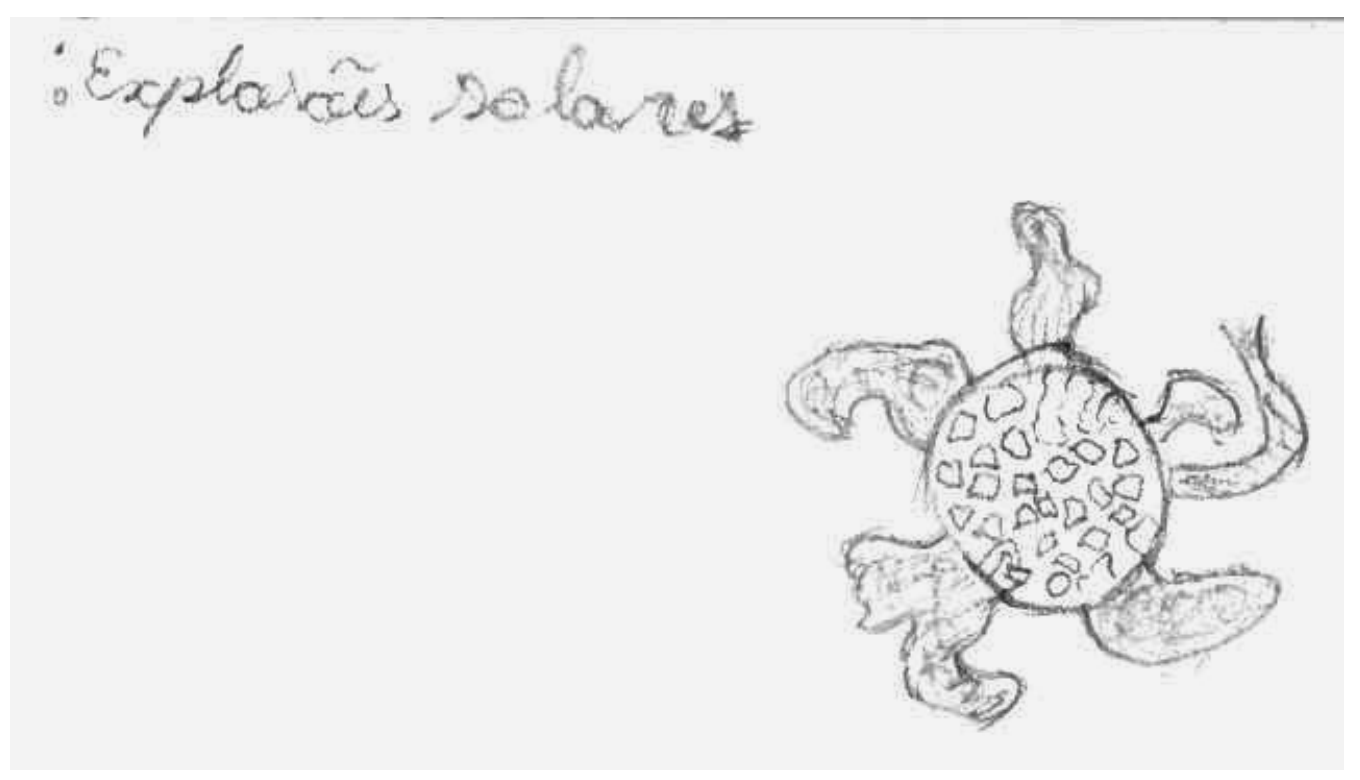

Figura 14 - Representação do Sol de um aluno de sétima série.

noção espacial mais acurada, porém mencionou "gêiseres" que são "explosões" que liberam água quente ou vapor de água para o ar. O aluno provavelmente desconhecia a definição de "gêiseres" tendo a usado no sentido das explosões ou arcos mencionado pelo aluno G6. Provavelmente, o aluno B6 acreditasse que as explosões causadas pelos "gêiseres" liberariam muita energia produzindo uma variação de laranja para amarelo no Sol.

A representação do Sol com manchas e arcos de hidrogênio, provavelmente foi influenciada por interesses prévios sobre o Sol dentro do Contexto Pessoal (FALK; DIERKING, 2000) onde o aluno buscou saber mais sobre o Sol. A aluna que escreveu no questionário inicial que esperava observar as explosões do Sol e o aluno que representou as explosões solares maiores que o próprio Sol, provavelmente viram imagens do Sol obtidas a partir de satélites na mídia, ou seja, teriam sofrido influência de conhecimentos prévios do Contexto Pessoal. Já a concepção de que as explosões solares são gêisers é fruto de conhecimentos sobre fenômenos que ocorrem na Terra, ou seja, conhecimentos prévios do Contexto Pessoal que foram usados para explicar fenômenos que ocorrem no Sol.

Em relação à constituição física do Sol, a aluna J7. da sexta série de 2007 escreveu no questionário inicial que esperava observar o Sol vermelho cheio de buracos e explosões, uma outra aluna, C7. da oitava série, de 2007 escreveu "a superfície do Sol deve ser cheia de buracos devido a sua alta temperatura". O aluno R7. da oitava série, apresentando a 

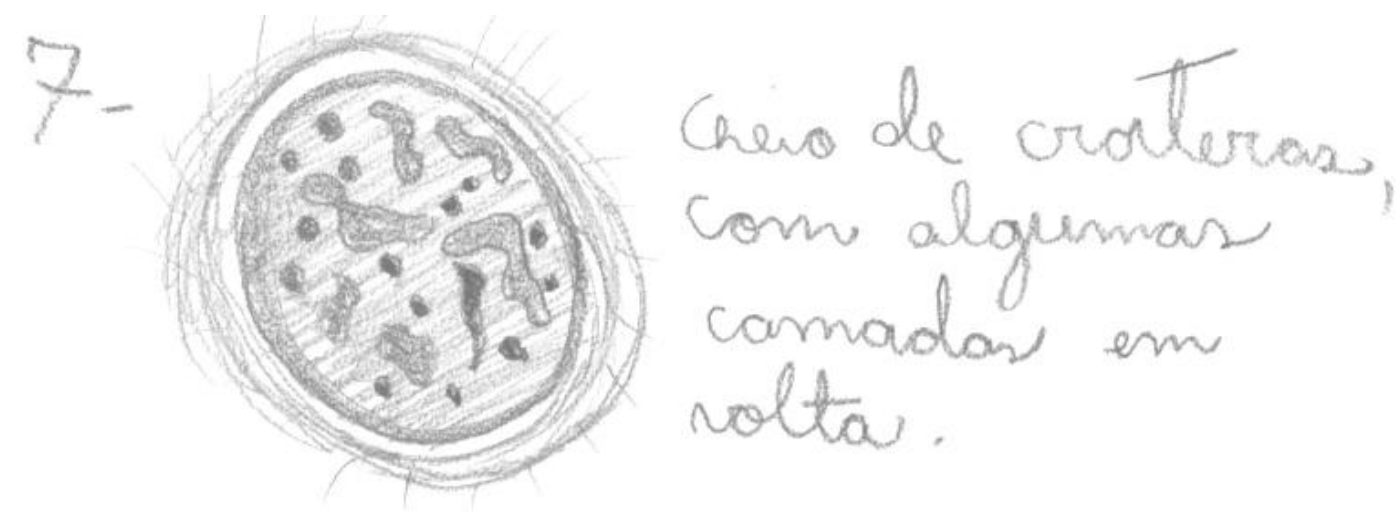

Figura 15 - Representação do Sol de um aluno de oitava série.

mesma concepção, desenhou o Sol repleto de buracos como pode ser visto na Figura 15. Esta representação de buracos no Sol também pode ser vista na figura 14 de G7.

Estes alunos, provavelmente devem ter visto imagens do Sol na mídia apresentando manchas escuras, e a explicação alternativa dos estudantes para estas manchas seriam buracos formados devido à alta temperatura no Sol. Alguns alunos usaram seus conhecimentos de geologia como, por exemplo, lava e magma adquiridos nas aulas de ciências para tentarem explicar o Sol, ou seja, partiram de algo conhecido em busca de explicações para algo novo, usando com isto seus conhecimentos prévios e experiências do Contexto Pessoal e Sócio-Cultural. As crianças aprendem sobre as camadas da Terra, sobre a existência de magna em altíssima temperatura em seu interior e sobre os vulcões. Provavelmente tentaram usar estes conhecimentos para explicar as manchas solares, já que sabiam que o Sol também é quente.

Notamos que as representações do Sol feitas pelos alunos de quinta à oitava séries oscilam entre o realismo ingênuo (Sol com raios e planetas, buracos em sua superfície) e o conceitual (Sol esférico com proeminências e manchas solares) originando representações intermediárias que é uma busca de conciliação entre os dois extremos. Resultados semelhantes foram obtidos por Bisch em sua pesquisa ao analisar os modelos de universo de alunos do ensino fundamental (BISCH, 1998). 


\subsubsection{Observação e natureza das manchas solares}

Com o objetivo de visualizar as manchas solares, projetamos o Sol num anteparo contendo uma folha de papel em branco no refrator Grubb (figura 6 do capítulo 4) ou num anteparo com o heliostato (figura 4 do capítulo 4). O Sol apareceu luminoso com pequenos grupos de manchas, ou sem mancha alguma. Durante as observações das manchas solares, os alunos foram encorajados a elaborar hipóteses para explicar o que seriam as tais manchas observadas. Abaixo temos um trecho extraído do mini-curso de 2007 com os alunos de sétima e oitava série sobre suas concepções de explosões e manchas solares associadas, respectivamente a bolhas e lava seca no Sol.

Prof: Será que vão aparecer manchas no Sol sendo que não vemos nenhuma hoje?

Aluno G7 da sétima série: Vai sim quando a superfície do Sol vai se secando e esfriando e escurecendo como se fosse a lava quando está quente, é vermelha quando seca fica escura.

Prof: Mas do que será que o Sol é feito?

Aluno G7 da sétima série: lava

Aluno R7 da oitava série : fogo

Aluno E7 da oitava série : rocha derretida e magma

Prof: Como se formam as manchas?

Aluno R7 da oitava série: explosões

Prof: Como se formam as explosões?

Aluno E7 da oitava série: por causa das bolhas

Prof: Que bolhas?

Aluno E7 da oitava série: quando ta fervendo água forma bolhas que são como explosões.

Prof: As explosões são as manchas?

Aluno E7 da oitava série: não, ela tem que secar para virar mancha. 
No diálogo acima podemos perceber que os alunos elaboraram um modelo em conjunto para explicar a ausência e surgimento de manchas solares relacionadas às explosões no Sol usando conceitos gerais sobre a Terra. Segundo os alunos, a lava quente na superfície solar borbulha provocando as explosões solares que originam buracos que ao resfriarem provocam as manchas solares. De acordo com o modelo, não havia manchas no dia da observação porque a lava na superfície solar não havia resfriado e secado o suficiente para escurecer e originar manchas.

Ao elaborarem hipóteses sobre o que seriam as manchas solares e buscarem uma explicação coerente para a solução do problema, os alunos estabeleceram relações entre fatos e o objeto observado, o que aponta para o que Vygotsky chamou de pensamentos por complexos.

No diálogo abaixo dos alunos de 2006 podemos constatar que também acreditavam que as manchas solares seriam buracos no Sol gerados por explosões que se resfriaram. O curioso é que eles concebiam a superfície solar como sendo gasosa. Neste caso, os alunos adotaram, além de seus conceitos de geologia, o conhecimento científico de que o Sol é gasoso.

Prof: O que vocês acham que são estas manchas no Sol?

Aluno JE6. da oitava série: crateras

Aluna N6. da sétima série: explosões

Prof: Do que o Sol é feito?

Aluno E6. da oitava série: gás

Prof: Como que as crateras são formadas?

Aluno JE6. da oitava série: explode e depois esfria.

Prof: Como é possível ter crateras no Sol?

Aluno JE6. da oitava série: não sei

Prof: Por exemplo, se eu jogar uma pedra na água você vai ver uma onda.

Ela vai continuar assim para sempre?

Aluno JE6. da oitava série: não

Prof: Imagine que tenha uma caixa cheia de ar e você joga uma pedra 
lá dentro vai fazer algum efeito que você possa ver há longo prazo dentro da caixa?

Alunos: não

Prof: E se você tiver um barro meio molhado e você jogar uma pedra lá. Depois que o barro secar o que vai acontecer?

Aluna N6. da sétima série: vai ficar uma marca.

Prof: Mas como você pode ter uma cratera num gás?

Aluna B6 da sétima série: acho que não

Prof: Mas não é a mesma coisa de você ter uma caixa cheia de ar e jogar uma pedra. Não concluímos que não acontece nada?

Aluno JE6. da oitava série: às vezes pode mudar a densidade do gás.

Prof: Mas se ainda é gás será que ia fazer um buraco no Sol?

Aluno JE6. da oitava série: acho que não

Neste diálogo os alunos associaram suas experiências prévias do Contexto Pessoal (crateras na Terra) a seus conhecimentos prévios de que o Sol é gasoso, mas não foram capazes de desenvolver um modelo coerente para explicar o surgimento das manchas e proeminências solares partindo simultaneamente das duas premissas.

Após observarem o Sol projetado, os alunos de 2006 notaram que não havia arcos ou "gêiseres", apenas manchas escuras sobre um disco amarelo claro. Isto fez com que no questionário final respondessem que observaram apenas manchas solares. No questionário final dos alunos dos minicursos de 2007 havia desenhos de proeminências solares (eles de fato as observaram) e outros desenhos mostrando um disco do Sol em branco (o que é coerente uma vez que no curso de 2007 não foi possível observar manchas no Sol).

Um aluno de oitava série de 2006, por sua vez, afirmou no questionário final que observou no Sol manchas e frequência dos raios emitidos. No questionário inicial apenas escreveu que veria uma esfera branca e brilhante. O curioso que mesmo após observar o Sol projetado que se assemelha a um disco, não apresentando "raios solares", o aluno escreveu "raios emitidos". 
"Raios solares" ou "raios emitidos pelo Sol" são termos muito usados na mídia, mas não são algo concreto no sentido de que seja possível ver ou tocar. São construções abstratas do pensamento humano para representar a radiação emitida pelo Sol.

Ao final da discussão de 2006 a professora perguntou aos alunos se veriam as mesmas manchas na próxima semana que viessem ao Observatório e no final da discussão de 2007, se da próxima vez que viessem veriam alguma mancha. A maior parte dos alunos de 2006 afirmou que não veriam as mesmas manchas, mas, divergiram quanto às suas razões para isto. Houve alunos que responderam que é porque a Terra gira em volta de seu eixo ou mesmo por causa da órbita da Terra em volta do Sol e ainda outros afirmaram que é porque as manchas mudam de posição devido à rotação solar.

Com a intenção de explicar aos alunos que o movimento das manchas solares, observado durante o mini-curso não ocorre devido à translação da Terra, foi mostrado que durante um dia, ou mesmo uma semana, a Terra percorre um trecho muito pequeno em volta do Sol de maneira que não altera o que observamos na superfície solar. Para ilustrar este movimento, foi usado um globo terrestre que representou a Terra e um aluno que representou o Sol. A professora com o globo em mãos, foi andando lentamente em volta do Sol, ao mesmo tempo em que rotacionava o globo para que os alunos percebessem que ambos os movimentos da Terra não afetam o que vemos no Sol num tempo curto. Mas, foi ressaltado, que o movimento de translação da Terra em volta do Sol pode interferir no que observamos no Sol num espaço de tempo de alguns meses uma vez que, passamos a enxergar, outras posições da esfera solar devido aos pontos distintos de sua órbita, nas quais a Terra se encontra ao longo do ano. Sendo assim, foi mostrado que a verdadeira causa da mudança na posição das manchas solares observadas durante o mini-curso advém da rotação solar e não da translação e rotação terrestres.

No modelo para explicar a ausência e surgimento de manchas solares relacionadas às explosões no Sol notamos uma forte influência do Contexto Pessoal ao usarem conhecimentos prévios de geologia, ao mesmo tempo, houve também a influência do Contexto Sócio-Cultural na medida em que o conhecimento foi sendo construído por meio de diálogos mediados pelo grupo e pela professora. Os alunos que mencionaram o termo "raios 
solares " no questionário inicial, provavelmente devem ter visto a luz solar sendo refletida por nuvens, o que de fato se assemelha a raios emitidos pelo Sol que atravessariam as nuvens, ou seja, usaram experiências prévias do Contexto Pessoal para explicar o que esperava observar no Sol.

A concepção de que o movimento das manchas solares ocorre porque a Terra gira em volta de seu eixo é provavelmente resultado de conhecimentos sobre a ocorrência do dia e noite usados para tentar explicar o movimento das manchas solares, ou seja, partiram de conhecimentos prévios do Contexto Pessoal que aprenderam na escola. Já a resposta de que o movimento das manchas solares ocorre devido ao movimento da Terra em torno do Sol (conhecimentos prévios de livros didáticos), mostra que os alunos desconheciam o fato de o Sol estar muito longe da Terra, e que, portanto isto influencia muito pouco no movimento das manchas solares de um dia para o outro. Por fim, os alunos que responderam que é devido à rotação solar, provavelmente aprenderam isto em livros de Astronomia ou por outras formas de divulgação ou seja, por interesses prévios do Contexto Pessoal sobre o tema.

Outro problema a ser resolvido pelos cientistas desde as primeiras observações do Sol foi entender como que as manchas solares se originaram. Hoje se sabe que sua origem está estreitamente correlacionada ao comportamento magnético do Sol (conforme explicado no apêndice A) e sua rotação que provoca "nós" nas linhas de campo magnético, impedindo que o calor do interior do Sol chegue até sua superfície, resfriando estas regiões e assim originando as manchas solares.

Durante os minicursos foi perguntado aos alunos o porquê das manchas solares serem regiões mais frias na superfície solar, o aluno G7. da sétima série de 2007 respondeu que é porque o "ar do Universo" acaba esfriando a superfície do Sol nas regiões das manchas. Ao perguntar ao mesmo aluno se o Sol não deveria se resfriar como um todo por estar em contato com o "ar do Universo" ele respondeu que as manchas devem ter algum tipo de proteção. Esta resposta serviu de gancho para introduzir a idéia que o campo magnético nas manchas solares, as protegem do calor oriundo do interior solar. Ao final da discussão, o aluno compreendeu que não há necessidade de se ter um ar permeando o Universo, uma 
vez que, o campo magnético localizado nas manchas já seria o suficiente para cumprir o papel de resfriá-las.

Com a intenção de introduzir a natureza magnética das manchas solares, por meio de uma atividade prática, recorremos a ímãs, papéis, imagens de manchas solares e palhas de aço. A configuração das palhas de aço sobre influência do campo magnético do ímã foi comparada às imagens de manchas solares (cujas configurações são semelhantes) como na figura 30 do apêndice A. Esta comparação permitiu reforçar a idéia de que as manchas solares são como gigantescos ímãs no Sol. A professora explicou que o campo magnético faz com que o calor oriundo do interior solar não consiga penetrar na região das manchas, resfriando-as.

Esta atividade foi interessante porque permitiu aos alunos entenderem que as forças físicas que agem na Terra também atuam em objetos celestes, reforçando a idéia de que a Terra é mais um planeta entre tantos outros do Universo e que as leis físicas são as mesmas em todo o Universo.

Comparando os questionários escritos, falas dos alunos, entrevistas finais e questionário finais notamos também que houve um desenvolvimento dos conceitos realistas ingênuos (manchas solares como buracos na superfície solar) em direção a níveis mais abstratos (manchas solares sendo regiões mais frias) em direção ao concreto e particular (manchas solares sendo gases mais frios no Sol devido à alta intensidade do campo magnético), ambos processo complementares, segundo Vygotsky.

A concepção de que as manchas solares são regiões mais frias do Sol porque o "ar do universo" entra em contato com elas resfriando-as, é fruto de experiências prévias do Contexto Pessoal de que tudo que vemos na Terra está imerso dentro do ar atmosférico. A idéia inicial do aluno G7 aparentemente sofreu mudança por influência do Contexto Sócio-Cultural, após a discussão sobre os efeitos do campo magnético mediada pelo grupo e pela professora. 


\subsubsection{Observação de proeminências e a relação Sol-Terra}

Os alunos de 2007 puderam observar as "explosões" na cromosfera solar (apêndice A) denominadas de proeminências ou protuberâncias solares com o uso do filtro hidrogênioalfa (figura7 do capítulo 4). Pedimos a eles que desenhassem o que observaram e comparassem suas observações com as dos colegas. Tais discussões permitiram que confrontassem suas observações, notando mudanças nas estruturas das proeminências (podem mudar de aspecto em alguns minutos). Na figura 16 podemos ver o desenho de proeminências solares observadas pela aluna A7. da sexta série pelo refrator principal com o uso do filtro hidrogênio-alfa (figura 8 do capítulo 4). Por fim, pedimos que classificassem as proeminências solares de acordo com o tipo segundo a classificação de Zirin (1988) mostrado na figura 17.

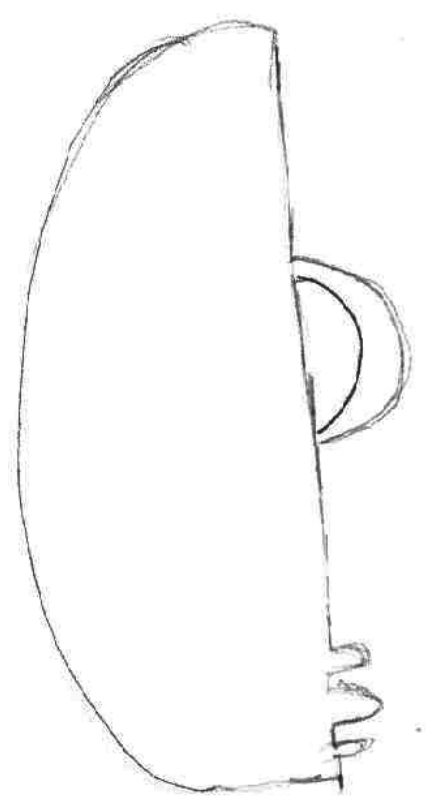

Figura 16 - Representação de proeminências solares observadas pelo telescópio por uma aluna de sexta série.

Outra atividade foi discutir sobre as influências da atividade solar sobre a Terra. No questionário inicial de 2007 foi perguntado aos alunos se o Sol pode influenciar a Terra e como seria esta influência. Alguns alunos de quinta, sexta, sétima e oitava séries escreveram que o Sol influencia a Terra somente emitindo luz e calor, pois segundo eles o Sol não influencia nas telecomunicações. ${ }^{4}$ A aluna J7. da sexta série de 2007 escreveu, " $a$

\footnotetext{
${ }^{4}$ Breve explicação sobre as influências da atividade solar sobre a Terra encontra-se no apêndice A.
} 


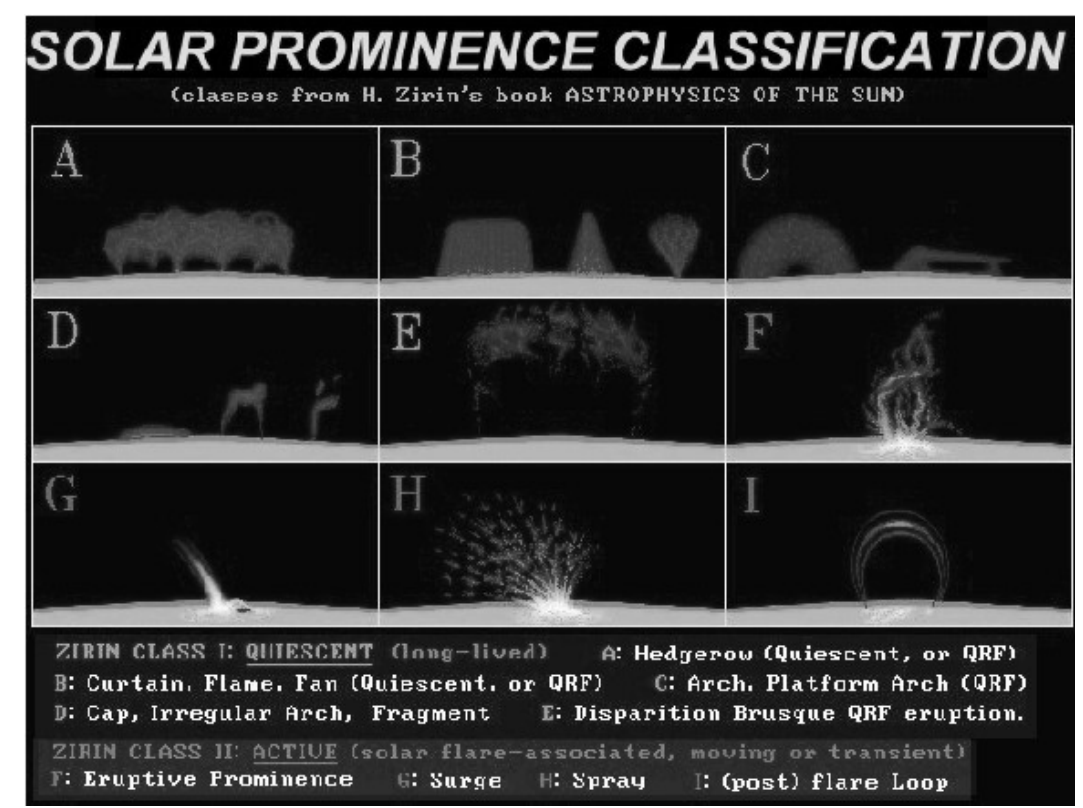

Figura 17 - Classificação de proeminências solares (ZIRIN, 1988).

radiação solar não interfere, pois os raios solares ultrapassam os sinais de rádio ou $T V$ a cabo sem interferir em nada". A aluna desconhecia outros tipos de radiações emitidas pelo Sol que poderiam afetar satélites e a ionosfera terrestre. Os alunos provavelmente não sabiam que o Sol pode influenciar as telecomunicações porque isto é pouco divulgado.

A aluna, da oitava série de 2007 foi uma das poucas que afirmou que o Sol pode influenciar a Terra, e segundo ela seria afetando satélites e equipamentos no espaço derretendo-os. Outra concepção curiosa foi da aluna B7. da oitava série que comentou não ter certeza se o Sol pode influenciar as telecomunicações e os astronautas, mas que talvez fosse possível sim, de acordo com a configuração do Sistema Solar. A aluna parece acreditar que a disposição dos planetas pode afetar a radiação emitida pelo Sol, numa concepção próxima da astrologia.

O tema influências da atividade solar sobre a Terra foi explicado e discutido usando slides no Power Point, conforme consta no apêndice A. Os alunos em geral ficaram surpreendidos com os efeitos que o Sol pode causar sobre a Terra, como, por exemplo, as auroras, tempestades geomagnéticas, mudanças de temperatura além de interferências nas telecomunicações.

Muitos alunos mencionaram no questionário final que as alterações na altura da ionosfera como sendo a principal interferência causada pelo Sol, aspecto que foi enfatizado 
no curso, já que é responsável, por interferências em rádio, satélites e pela formação de auroras. Alguns alunos apenas mencionaram que o Sol pode afetar a Terra por radiações e explosões solares (Flares), outros que o Sol pode provocar alterações no clima terrestre. Somente um aluno de sexta série escreveu que o Sol pode afetar " rádios, televisões, microondas" , mostrando que ele não compreendeu como as tempestades geomagnéticas podem afetar a Terra.

Pelas respostas dos alunos é possível verificar que antes da realização dos minicursos, havia um desconhecimento de explosões solares energéticas como os flares e proeminências, além dos tipos de radiações emitidas pelo Sol como o ultravioleta, raios X e raios gama. No entanto, após realizarem o mini-curso os alunos ampliaram seus conhecimentos acerca das influências da atividade solar sobre a Terra, compreendendo que o astro rei influencia a vida na Terra muito mais do que emitindo luz e calor .

Tal discussão foi fundamental para mostrar que o Sol é, além de uma importante fonte de energia para todos os planetas do Sistema Solar, uma estrela dinâmica que apresenta períodos menos estáveis e que durante estes períodos ocorrem tempestades geomagnéticas (na Terra) que podem influenciar na transmissão de dados de satélites para a Terra, na fiação elétrica e nos astronautas em órbita. Ou seja, estamos cada vez mais vulneráveis à ação do Sol à medida que nossa tecnologia baseada em ondas eletromagnéticas progride.

A aluna que afirmou no questionário inicial que o Sol pode afetar a Terra derretendo satélites usou suas experiências prévias do Contexto Pessoal de que o Sol é uma fonte de calor capaz de provocar queimaduras na superfície terrestre e assumiu que o mesmo ocorre com os satélites em órbita. De fato, os satélites podem ser destruídos pela intensa atividade solar, mas não somente por queimaduras, podendo, por exemplo, sofrer um desvio em sua órbita provocando a queda do satélite, conforme explicado no apêndice A. A idéia de que a configuração do Sistema Solar pode afetar a Terra, provavelmente foi influenciada por jornais, revistas e outros materiais, conhecimentos prévios do Contexto Pessoal, contendo informações (nada científicas) sobre as influências que os planetas e o Sol exercem na vida das pessoas. Podemos afirmar que as discussões realizadas durante o curso, o Contexto Sócio-Cultural interferiram nas respostas ao questionário final dos alunos, pois 
a maior parte dos alunos compreendeu que o Sol pode afetar a Terra, especialmente as telecomunicações.

\subsubsection{Alguns comentários}

As atividades desenvolvidas propiciaram discussões sobre as dimensões do Sol e sua distância à Terra, outro aspecto importante foi mostrar os métodos de observação solar e que os mesmos exigem extremo cuidado e que não devem ser realizados sem a orientação e supervisão de um especialista. Além de noções sobre a constituição física do Sol, como este produz energia, noções de que o Sol é um astro dinâmico, na medida em que foi possível acompanhar o movimento e surgimento de manchas e proeminências solares e explorar as influências que o Sol exerce sobre a Terra.

Os alunos de quinta à oitava série apresentaram pré-concepções interessantes sobre o Sol, manchas solares e proeminências. Alguns alunos foram capazes de desenvolver um modelo para explicar o surgimento das manchas solares em grupo baseados em seus conhecimentos, experiências e interesses prévios. Tal modelo foi confrontado com observações, discussões em grupo e com a professora, de maneira que no questionário final apresentaram concepções mais próximas às aceitas pela comunidade científica.

Como atividade de avaliação final foi solicitado que os alunos fizessem um livro sobre o Sol como pré-requisito para obtenção de certificado nos minicursos de 2007 (figuras 18, 19 e 20). Com isto, poderiam aprender mais sobre o Sol estudando em casa e inclusive comentando sobre o curso com seus pais e amigos, além de trazerem mais elementos para serem discutidas nos minicursos.

Com esta atividade foi possível que os alunos sistematizassem seus conhecimentos sobre o Sol. Nenhum dos livrinhos está totalmente isento de erros conceituais, como era de se esperar devido ao pouco tempo de curso, a idade dos alunos, e a quantidade de novas informações ensinadas. No entanto, um livro isento de erros não foi o principal objetivo da atividade, mas sim avaliar alguns dos ganhos cognitivos dos alunos. Notamos que os alunos não apresentaram as pré-concepções detectadas nos questionários iniciais. Apenas pela análise dos livros confeccionados pelos alunos não foi possível saber o motivo exato de não 


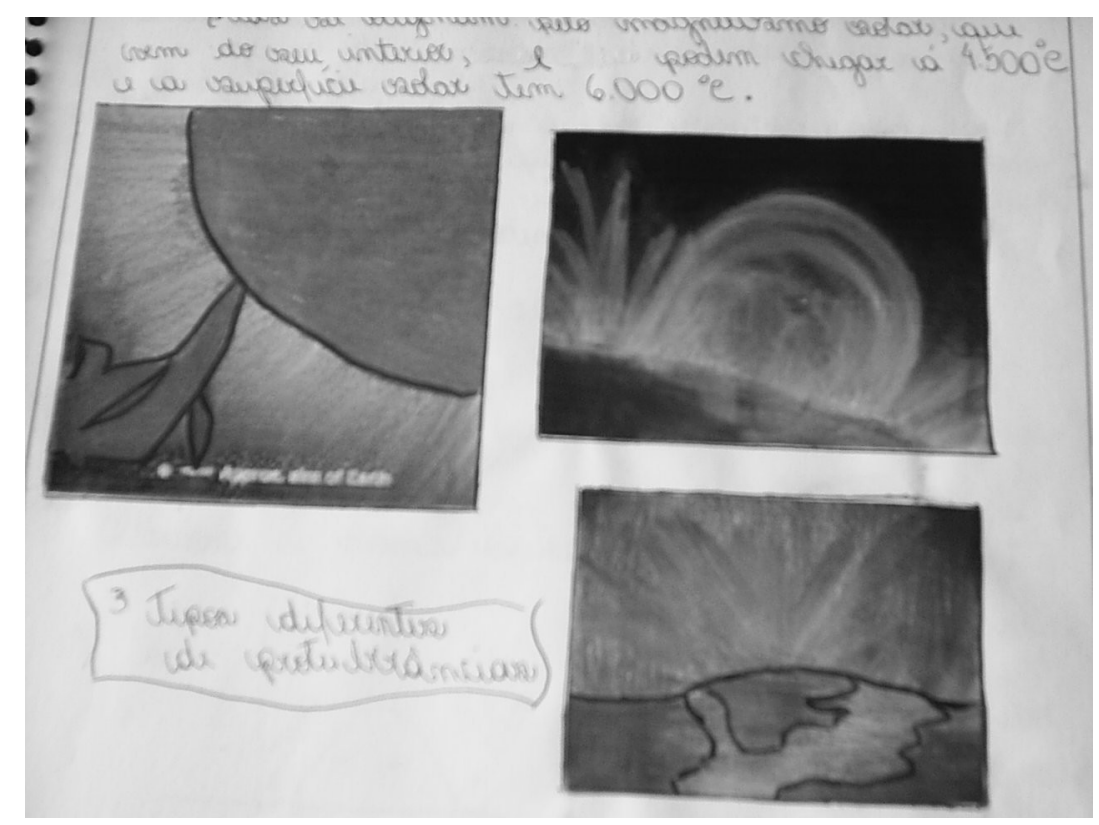

Figura 18 - Imagem de dentro do livro premiado de uma aluna da sexta série.

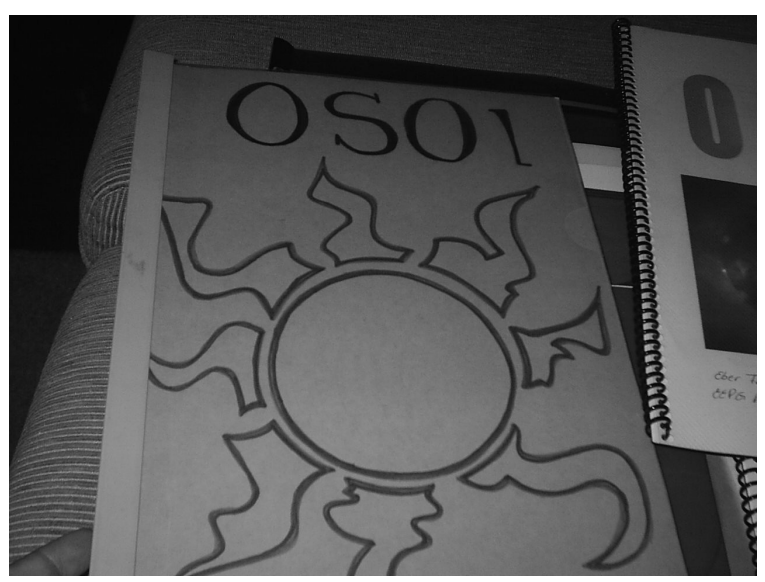

Figura 19 - Capa do livro de uma aluna de oitava série.

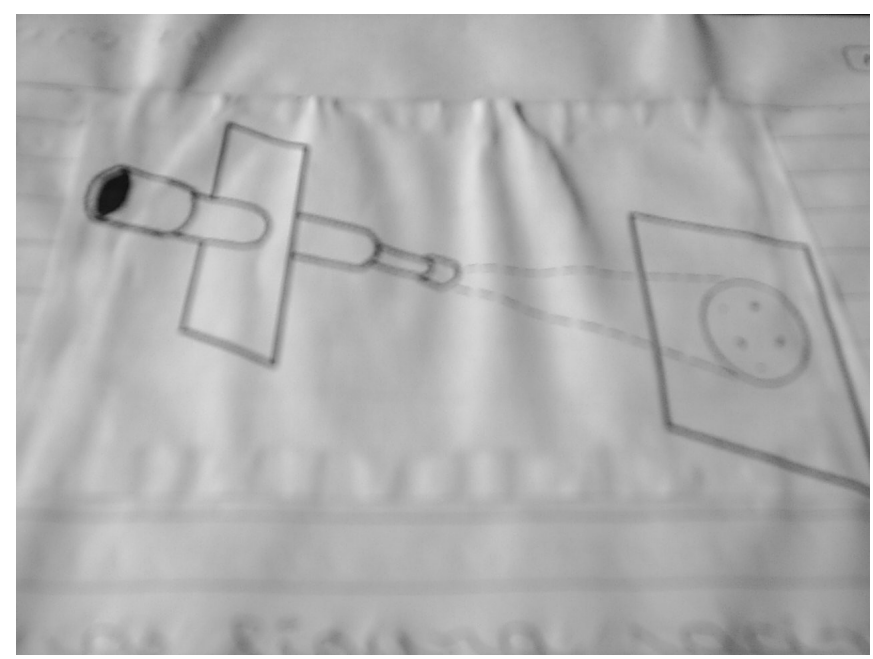

Figura 20 - Desenho de dentro do livro de uma aluna de oitava série mostrando o método de projeção solar usado durante o mini-curs o. 
terem apresentado pré-concepções. Contudo, devido ao fato de outros instrumentos terem sido usados (questionários escritos, filmagens das aulas e das entrevistas), acreditamos que a ausência de pré-concepções seja devido à uma combinação estratégica usada nos minicursos em que as pré-concepções foram confrontadas e os alunos se convenceram de concepções mais aceitas pela comunidade científica, uma vez que puderam observar o Sol e discutir hipóteses para explicar o que observaram. 


\section{$6 \quad$ Física solar para o ensino médio}

Apresentamos neste capítulo uma proposta de ensino interdisciplinar sobre o Sol e seu espectro em um espaço não formal de educação para alunos do ensino médio. Aplicamos a proposta por meio de um curso denominado de Física Solar desenvolvido no Observatório Astronômico do CDCC/USP para avaliar como as atividades sugeridas contribuíram no entendimento do tema "Sol" e aspectos da física solar.

\subsection{O contexto da proposta}

Tópicos como a composição química, temperatura e evolução estelares foram ensinados a partir de experimentos clássicos na sala solar (veja o capítulo 4) com equipamentos de baixo custo. O curso enfatizou atividades práticas, observacionais e questionadoras, como estimar a temperatura da fotosfera, observação do espectro solar na região do visível e identificação das linhas de absorção entendendo como são produzidas e que tipo de informações podem ser extraídas a partir delas. Os objetivos do curso foram compreender o papel chave desempenhado pela espectroscopia na astrofísica, contextualizar o conteúdo ensinado com atividades práticas e permitir abordagens interdisciplinares incluindo física moderna e química no ensino de astronomia.

\subsection{O curso}

A proposta para o ensino médio foi desenvolvida em um curso gratuito, denominado de Física Solar ministrado em outubro de 2007 no Observatório do CDCC/USP, com duração de 14 horas e subdivido em 5 aulas desenvolvidas durante 2 semanas. Os alunos participantes foram voluntários de escolas públicas e particulares do município de São Carlos. Com uma presença de pelo menos $75 \%$ e o cumprimento das atividades propostas, os alunos tiveram direito a um certificado de conclusão do curso.

A divulgação do curso Física Solar foi feita pela professora nas escolas, de maneira semelhante à realizada com os minicursos de 2007 do ensino fundamental. Tivemos 19 
alunos inscritos no curso, Física Solar, sendo que 13 destes inscritos, compareceram no primeiro dia do curso. Ainda assim, foi grande o número de alunos (11) que concluíram o curso. Destes 11 alunos, 3 foram de escolas públicas e os demais de escolas particulares do município de São Carlos.

\subsection{Metodologia}

A análise dos dados obtidos durante a pesquisa foi realizada de maneira qualitativa, conforme foi feito com os alunos do ensino fundamental. Ou seja, levantamos as concepções prévias dos alunos, registramos o curso por filmagens e pela aplicação de questionários escritos, antes e após a realização das atividades propostas e por meio de entrevistas. Ao fim do curso, os alunos foram entrevistados sobre suas pré-concepções registradas nos questionários escritos. Assim como no caso do ensino fundamental, as entrevistas foram individuais, compostas por três perguntas, realizadas de forma semi-estruturada.

A análise dos dados foi efetuada por meio de todas as respostas dadas pelos alunos, obtidos nos diferentes momentos de aquisição das mesmas, no desenvolvimento do curso, nos registros de observações do Sol e de seu espectro, nos pré e pós-questionários escritos, nas avaliações dos alunos, realizadas ao final do curso, em exposição oral, escrita e na discussão sobre as demais regiões do espectro solar.

A metodologia adotada no curso Física Solar foi a de diálogos expositivos envolvendo professora e alunos, incentivando a participação dos alunos por meio da realização de pequenos experimentos, ou seja, a mesma adotada com os alunos do ensino fundamental. Porém, os tópicos abordados não foram os mesmos; incluímos atividades que exigiam conceitos de calorimetria, geometria, corpo negro e óptica física. Estes conceitos foram introduzidos, discutidos e revisados. Ao final de cada dia do curso, os pontos mais relevantes ensinados no dia foram colocados na lousa com a participação dos alunos para organizarem seus conhecimentos. Também solicitamos que escrevessem suas avaliações pessoais sobre o curso, respondendo a algumas perguntas sem que fosse necessário se identificar.

Iniciamos o curso Física Solar aplicando um questionário escrito em que os alunos 
responderam às questões por meio de textos e desenhos, com o intuito de levantar suas concepções prévias dos temas que seriam abordados. Após a conclusão dos questionários apresentamos um panorama geral do curso explicando os temas que seriam abordados e as atividades que seriam realizadas. Em seguida, levantamos os motivos pelos quais os alunos achavam importante estudar o Sol. Após os alunos apresentarem seus pontos de vistas, discutimos as principais razões pelas quais os astrônomos e cientistas em geral estudam nossa estrela vizinha.

Os primeiros temas abordados foram as dimensões e distâncias do Sol relativas a Terra. Após ouvirmos as concepções dos alunos, usamos conceitos básicos de geometria e trigonometria para estimar a distância da Terra ao Sol e desenvolvemos uma atividade prática com materiais de baixo custo para estimar o diâmetro solar.

Ainda no primeiro dia do curso, discutimos as maneiras mais seguras de se observar o Sol. Foram discutidos os métodos de projeção solar e observação direta (com o uso de filtro), além de apresentarmos modelos distintos de telescópios e explicar quais eram os mais indicados para a observação solar. Ao fim do primeiro dia do curso foram debatidas a natureza das manchas solares e proeminências, após a observação das mesmas. Por fim, foi discutido o motivo pelo qual não vemos as proeminências solares com um filtro solar comum e com isto, a necessidade do uso de um filtro hidrogênio-alfa (ver capítulo 4).

No dia seguinte, mostramos um eletroímã que foi especialmente construído para discutirmos sobre a origem magnética de manchas solares. A corrente que atravessa o fio do eletroimã faz com que o mesmo seja um imã temporário, capaz de atrair pequenos clipes. Ímãs possuem campos magnéticos responsáveis pela atração e repulsão de materiais magnéticos. Na fotosfera, as regiões onde há campos magnéticos intensos dificultam o transporte de calor da zona de convecção para a fotosfera, provocando o resfriamento destas regiões e consequentemente, o surgimento de manchas solares. Esta atividade propiciou uma melhor compreensão do porquê das manchas solares serem regiões mais frias que a fotosfera.

Outra etapa deste mesmo dia consistiu em determinar a potência emitida pelo Sol por meio de uma atividade prática e conceitos de calorimetria tratando o Sol como um corpo 
negro. Para tanto, discutimos estes conceitos e mostramos como a partir deles é possível estimar a temperatura na fotosfera solar.

A última parte do segundo dia do curso foi mais teórica na medida em que foi voltada para uma discussão de como o Sol produz e transporta sua energia. As analogias discutidas foram as mesmas usadas com os alunos do ensino fundamental, porém as discussões dos processos de produção de energia no Sol foram mais detalhadas.

O terceiro dia do curso foi focado na observação do espectro solar buscando compreender o seu significado e como o mesmo é formado. Para introduzir os fenômenos de refração e difração, responsáveis pela obtenção do espectro solar usamos prismas, redes de difração e lâmpadas de gases. Os alunos observaram o espectro das lâmpadas e discutimos as semelhanças e diferenças entre os espectros. Em seguida, mostramos o aparato experimental de observação do espectro solar e projetamos o espectro na parede. Por fim, identificamos algumas das linhas de absorção do Sol e as comparamos com o espectro das lâmpadas de gases.

No quarto dia do curso, abordamos noções básicas de evolução estelar e explicamos que o Sol é incapaz de sintetizar elementos químicos presentes em seu espectro como mercúrio, ferro e cálcio. Além disso aplicamos o questionário final e realizamos as entrevistas finais com os alunos. Por fim. foi discutida a existência de radiações com comprimentos de onda acima e abaixo da região do visível. Esta discussão foi importante para os alunos saberem que o espectro solar não está restrito somente à região do visível, e consequentemente, como a astrofísica é altamente dependente da parte invisível do espectro eletromagnético.

\subsection{Discussão dos resultados}

Assim como no caso do ensino fundamental, optamos por analisar os dados obtidos à luz do Modelo Contextual de Aprendizagem de Falk e Dierking (2000), por contemplar a interação dos diferentes contextos responsáveis pela aprendizagem em museus de ciências, e não somente os ganhos cognitivos dos alunos, após a realização do curso Física Solar . 


\subsubsection{Estimativa geométrica da distância da Terra ao Sol e seu tamanho relativo}

No questionário inicial (apêndice D), foi perguntado se é a Lua ou o Sol, que se encontra mais próximo da Terra e qual a distância da Terra ao Sol. O aluno V. do primeiro ano escreveu: "A Lua está em constante movimento ao redor da Terra. Levando isso em consideração, há trechos de seu caminho onde ela está mais próxima do Sol do que o planeta Terra. O Sol está a 150 bilhões de quilômetros da Terra." O aluno não considerou a distância da Terra à Lua desprezível em relação à distância da Terra ao Sol (400 vezes maior) porque acreditava que os objetos do Sistema Solar estão todos próximos entre si. Alguns alunos ainda, responderam que o Sol está mais perto da Terra do que a Lua. Estas concepções são provavelmente oriundas de livros didáticos que apresentam um Sistema Solar fora de escala, sem explicar aos alunos as distâncias envolvidas.

Houve também respostas nas quais os alunos afirmaram que o Sol está mais longe da Terra do que a Lua e deram suas distâncias em bilhões de anos luz. Neste último caso podemos afirmar que os alunos não sabiam que o ano luz é uma medida usada para objetos que estão além do Sistema Solar, bilhões de anos luz excede as próprias dimensões de nossa Galáxia (100000 anos luz)! Apenas 3 alunos responderam corretamente à pergunta e forneceram valores aceitáveis.

Antes da realização da atividade prática de se estimar o diâmetro solar, foi perguntado aos alunos o diâmetro relativo do Sol comparado ao da Terra, muitos alunos responderam que o Sol é maior do que a Terra. Em seguida, o aluno Wi. do terceiro ano respondeu que o Sol é cerca de 110 vezes maior do que a Terra e nenhum outro aluno discordou. Como, seus colegas já sabiam que o aluno Wi. é um fanático por Astronomia, assumiram que ele estava certo e não expressaram seus pensamentos, o que tornou dificil saber as pré-concepções de seus colegas, uma vez que esta pergunta não foi feita no questionário inicial.

No curso Física Solar buscamos demonstrar como foram obtidas a primeira estimativa da distância relativa Sol-Terra-Lua (c/b na figura 21) para que os alunos tivessem uma 


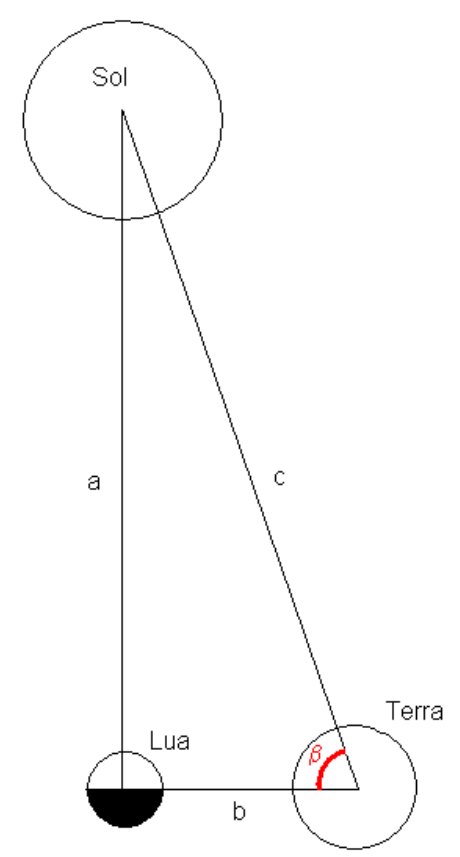

Figura 21 - Configuração do sistema Sol-Terra-Lua usado por Aristarco de Samos para estimar a distância da Terra ao Sol.

noção histórica de como isto foi feito e que não é necessário nenhum aparelho sofisticado para realizá-las. Para tanto, foram introduzidos os princípios matemáticos e astronômicos envolvidos nos cálculos. O astrônomo grego Aristarco de Samos (310-230 a.C.) foi o pioneiro nesta medida onde utilizou uma configuração específica do Sistema Sol-TerraLua, na qual o ângulo entre Sol, Lua e Terra é de noventa graus. Isto ocorre quando a Lua está exatamente na fase de quarto crescente ou em quarto minguante (figura 21). A partir disto ele mediu o ângulo formado entre a Lua e o Sol ( $\beta$ da figura 21) e com princípios de trigonometria e geometria (equações 1, 2 e 3) determinou quantas vezes mais longe o Sol encontra-se da Terra comparado à Lua. Estes cálculos mostraram à humanidade que o Sol está muito mais longe que se supunha na época.

$$
\frac{b}{c}=\cos \beta
$$

$$
\beta=87^{\circ}
$$




$$
\frac{c}{b}=\frac{1}{\cos \beta}=19
$$

Hoje sabemos que o ângulo correto é de aproximadamente $89^{\circ} 55^{\prime}$, o que corresponde a uma distância da Terra ao Sol 400 vezes superior à distância da Terra à Lua. Assim, para Aristarco, o Sol estaria cerca de 19 vezes mais distante da Terra do que a Lua. Ainda assim, a estimativa de Aristarco foi algo surpreendente para a época (FERRIS, 1990). Discutimos também, que esta distância corresponde à aproximadamente 150 milhões de quilômetros, que corresponde a 1 unidade astronômica, medida utilizada pelos astronômos dentro do Sistema Solar. Aproveitamos para explicar que o ano luz corresponde a cerca de 10 trilhões de quilômetro e que portanto é uma medida muito acima da unidade astronômica, e que a mesma é usada para medir a distância do Sol até as estrelas da Via Láctea.

Para estimar o diâmetro do Sol recorremos à uma atividade prática onde foi necessário um pedaço de cartolina preta, um compasso com ponta, uma folha de papel branco e um dia ensolarado conforme ilustrado na figura 22. Esta atividade ilustrou uma forma segura de se observar o Sol dispensando o uso de telescópio, bastante útil durante eclipses solares. Fizemos um furo na cartolina preta com a ponta de um compasso, em seguida apontamos a cartolina com o furo para o Sol e em baixo da cartolina colocamos a folha de papel branco, onde o Sol foi projetado. Afastamos o papel branco da cartolina preta até que obtivemos uma imagem do Sol com um tamanho mínimo que fosse possível medir com uma régua (RIORDAN, 2002). Sabendo as dimensões da imagem projetada (d), a distância entre a cartolina preta e o papel branco (h) e a distância da Terra até o Sol (150 milhões de quilômetros) estimamos o diâmetro solar (D). Para que os alunos tivessem noção de quantas vezes o Sol é maior que a Terra informamos o diâmetro terrestre, com este dado foi possível dividir a dimensão do Sol obtida na atividade pelo tamanho da Terra. Ao fazer isto concluíram que o diâmetro do Sol é cerca de 110 vezes maior do que o da Terra.

Um dos alunos que havia escrito no questionário inicial que a distância da Terra ao Sol é medida em ano luz respondeu na entrevista final, que a distância da Terra ao Sol é de milhões de quilômetros. Ainda assim, o aluno não soube precisar o valor exato da distância da Terra ao Sol, mas foi capaz de compreender que o ano luz é uma medida bem 


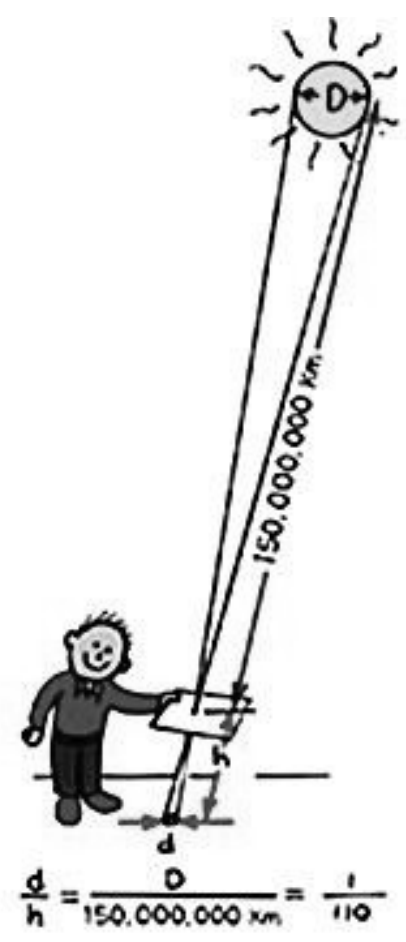

Figura 22 - Atividade para se estimar o diâmetro do Sol. Fonte da imagem: http://vts .bc. $\mathrm{ca} /$ pgrasc/Student_Handouts/solar_distance.html

superior à distância da Terra ao Sol, já que não mencionou o termo na entrevista final. Durante a entrevista final outro aluno afirmou que o diâmetro solar é 400 vezes maior do que o da Terra. Isto talvez tenha ocorrido porque confundiu quantas vezes o Sol está mais longe que a Lua da Terra (400 vezes) com quantas vezes o Sol é maior do que a Terra em diâmetro (110 vezes). Isso não é um problema, uma vez que o objetivo principal de tais atividades não é a memorização de valores, mas sim a construção de noções de distância e principalmente motivar os alunos a buscarem novos conhecimentos.

O Contexto Pessoal (FALK; DIERKING, 2000) exerceu um papel importante nas préconcepções apresentadas pelos alunos, como no caso do aluno V. do primeiro ano que provavelmente foi influenciado pelos conhecimentos prévios oriundos de livros didáticos que apresentam um Sistema Solar fora de escala de distância. Os alunos que afirmaram que o Sol está a bilhões de anos luz mais longe da Terra do que a Lua provavelmente escutaram o termo ano luz na mídia e, assim, também foram influenciados pelos conhecimentos prévios ao tentarem aplicá-los para a medida de distância da Terra ao Sol. Já os alunos que responderam que o Sol está mais perto da Terra do que a Lua, provavelmente usaram em suas respostas ao questionário inicial, experiências prévias de olharam para o Sol e 
verem o astro mais brilhante que a Lua, dando a impressão que é visualmente maior.

O Contexto Físico em que foi realizada a atividade de se estimar o diâmetro do Sol em relação ao da Terra, provavelmente influenciou na resposta do aluno de que o Sol possui um diâmetro 100 vezes maior do que o terrestre na entrevista final. O Contexto Sócio-Cultural por meio de discussões das medidas usadas dentro e fora do Sistema Solar, provavelmente influenciou nas respostas às entrevistas finais, pois os alunos apresentaram valores de distâncias dentro do Sistema Solar, e do diâmetro solar mais próximos aos valores reais do que no questionário inicial.

Como pode ser visto, nossos resultados concordam com os de Trumper (2001) que investigou alunos do ensino fundamental e médio de Israel, evidenciando que o ensino de Astronomia é um desafio enfrentado por diversos países com realidades educacionais bastante distintas. Podemos atribuir estas dificuldades ao fato de os currículos de ciências serem ainda bastante tradicionais centrados em conteúdos consagrados por autores de livros didáticos e na formação de professores. Inovações como as propostas pelos PCN+ constituem um desafio a ser enfrentado. Neste contexto, o presente trabalho traz contribuições importantes ao propor o ensino de física solar em um espaço não formal.

\subsubsection{Concepções sobre a natureza do Sol, manchas solares e proeminências}

Foi perguntado aos alunos no questionário inicial como é a superfície solar. Dois alunos, J. e P. do primeiro ano responderam que a superfície solar é parecida com a da Lua, quente contendo crateras. Na ocasião em que a professora divulgou o mini-curso nas escolas foram mostradas imagens do Sol contendo manchas solares, os alunos provavelmente as associaram a buracos na superfície solar. Outros dois alunos, R. do primeiro ano e We. do terceiro ano, responderam que a superfície solar é quente com magma e vulcões, apresentando concepções semelhantes a dos alunos do ensino fundamental. Quatro alunos, I., Ta. L., T. todos do segundo ano e os alunos Wi. e F., ambos do terceiro ano responderam que a superfície solar é gasosa. A aluna, F. do terceiro ano acrescentou que a superfície solar é repleta de explosões e o aluno Wi., afirmou que o Sol é composto por plasma e definiu o termo como sendo um gás ionizado. 
Em relação à pergunta do questionário inicial sobre o que esperavam observar no Sol por um telescópio, o aluno T. do segundo ano respondeu "explosões nucleares ocorrendo em sua superfície". A aluna F. do terceiro ano escreveu que esperava observar, além de manchas solares e explosões solares, "nuvens de gases e poeira". Os demais alunos esperavam observar manchas solares e explosões, sendo que alguns deles interpretaram explosões solares como sendo as reações nucleares que ocorrem no interior solar, por desconhecerem a existência de proeminências já que as mesmas são pouco divulgadas pela mídia.

Foi perguntado também, no questionário inicial (apêndice D), o que são as manchas solares. Uma concepção curiosa foi apresentada pela aluna I. do segundo ano que escreveu no questionário inicial, que as manchas solares poderiam ser estrelas. Os alunos J. do primeiro ano e We. do terceiro ano, afirmaram que as manchas solares seriam buracos na superfície solar. O aluno We havia respondido no questionário inicial que a superfície solar possui uma constituição vulcânica. Este aluno, possivelmente tenha uma concepção parecida com a apresentada pelos alunos do ensino fundamental, de que as manchas solares seriam provocadas por explosões de lava, que ao resfriar produziriam buracos escuros na superfície solar que resultariam em manchas solares. Cinco alunos, R., P. do ambos do primeiro ano, C, L e T., todos do segundo ano afirmaram, que as manchas solares são resultantes de explosões.

Já os alunos Ta. do segundo ano e F. do terceiro ano escreveram que as manchas solares seriam regiões onde ocorrem reações diferenciadas provocadas pela presença de gases distintos, das demais partes do Sol. Em relação à mesma questão, o aluno Wi. do terceiro ano apresentou a concepção mais próxima à aceita pelos cientistas, a de que as manchas solares seriam regiões mais frias da superfície solar associadas à presença de campo magnético.

No que diz respeito à pergunta do questionário inicial sobre quais cuidados devemos ter ao observar o Sol pelo telescópio, todos alunos responderam que o Sol deve ser observado com proteção, alguns mencionaram filtro, mas nenhum aluno citou o método de projeção solar. Os alunos em geral sabiam que o Sol pode causar câncer de pele, resultante do que 
aprenderam com conversas com colegas e pais, portanto sofreram influência do Contexto Sócio-Cultural e ao mesmo tempo, conheciam as queimaduras que o Sol pode provocar ao permanecerem longo tempo em piscinas ou praias sem o uso de filtro solar, ou seja, possuem experiências prévias do Contexto Pessoal sobre o assunto. Portanto, era de se esperar que os alunos soubessem que nunca se deve apontar um telescópio para o Sol sem determinados cuidados.

Ao iniciar as atividades do curso discutimos a importância de se observar o Sol com extremo cuidado, conforme foi feito com os alunos do ensino fundamental, bem como os principais métodos de observação solar. Ao apontar o telescópio para o Sol não foi possível observar mancha alguma em sua superfície, devido ao fato de este se encontrar no fim de um de seus ciclos de atividade solar. Os alunos apenas observaram a projeção do disco solar e a turbulência nas bordas da imagem do disco devido às instabilidades de nossa atmosfera. Felizmente, com o uso do filtro hidrogênio-alfa foi possível observar duas proeminências na borda do Sol.

Como não havia manchas no Sol, mostramos imagens de manchas solares de anos anteriores, para exemplificar o movimento e evolução das mesmas ao longo de dias consecutivos de observação. Além disso construímos um eletroimã para explicar que as manchas solares estão associadas a regiões de campo magnético intenso. O eletroimã é composto por uma pilha ligada a um fio de cobre comprido enrolado em um prego grande. A corrente que passa pelo fio transforma o eletroimã em um imã temporário, capaz de atrair pequenos clipes. Imãs possuem campos magnéticos responsáveis pela atração e repulsão de materiais magnéticos. Na fotosfera, as regiões onde há campos magnéticos intensos dificultam o transporte de calor da zona de convecção para a fotosfera, provocando o resfriamento destas regiões e originando as manchas solares.

Os alunos em geral foram capazes de descrever os dois métodos de observação solar no questionário final. O método de projeção, segundo os alunos, consiste em projetar a imagem do Sol por um telescópio em um anteparo, alguns mencionaram que é necessário usar filtros especiais durante a observação por projeção, o que não é verdade. Ao mesmo tempo, dois alunos especificaram que a ocular do telescópio no método de projeção precisa 
ser de um material resistente ao calor solar, como o quartzo fundido. O método de observação direta, também foi chamado por alguns alunos de método normal de observação em que se usa um filtro, mas poucos mencionaram que o filtro solar deve ser colocado na objetiva do telescópio, jamais na ocular.

No questionário final, nenhum aluno afirmou que o Sol é composto por magma, vulcões ou crateras. Isto provavelmente ocorreu porque os alunos perceberam que as manchas solares não poderiam ser explicadas como sendo vulcões ou buracos existentes sobre um material gasoso. As concepções dos alunos teriam entrado em um conflito provocando, o que Piaget denominou de mudanças nos esquemas de assimilação em direção à acomodação, que seria uma concepção de que as manchas solares estariam lá por outra origem que não o vulcanismo ou magma.

Todos os alunos afirmaram, no questionário final, que as manchas solares são regiões mais frias que a fotosfera associadas à presença de campos magnéticos. A aluna C. do segundo ano, que havia escrito no questionário inicial que as manchas solares são decorrentes de explosões e que o Sol possui uma superfície vulcânica, escreveu, no questionário final, que as manchas solares "[...] são áreas mais frias que o resto da superfície pois o magnetismo é como uma bolha que a isola. Dependendo da atividade solar ocorrem com maior ou menor frequência ." Esta resposta mostrou que a aluna compreendeu que as manchas solares não são resultantes de explosões na superfície solar, e ao mesmo tempo, usou a analogia apresentada no curso de que o campo magnético solar atua como se fosse bolhas no Sol impedindo que uma certa quantidade de radiação oriunda da zona de convecção atinja determinadas regiões da superfície solar para explicar a origem das manchas solares.

Abaixo temos um trecho da entrevista final com o aluno L. do segundo ano sobre o que seriam as manchas solares. Este mesmo aluno havia escrito no questionário inicial que o Sol é gasoso, constituído por hidrogênio e que as manchas solares seriam resultantes de explosões em sua superfície.

Prof: O que são manchas solares?

Aluno L do segundo ano: pontos negros por causa da diferença de tempera- 
tura inferior causados pelo campo magnético. O campo magnético sai de uma mancha e entra em outra, são sempre em pares, daí tem a rotação do Sol que influencia também.

Prof: Mas, por que as manchas solares são mais frias que o restante da superfície do Sol?

Silêncio

Prof: Lembra o que existe embaixo da fotosfera?

Aluno L do segundo ano: camadas de convecção.

Prof: Isso, ai acontece o quê?

Aluno L do segundo ano: o campo magnético deve influenciar, reduz a intensidade da conveç̧ão.

O trecho da entrevista final com o aluno mostrou que ele compreendeu que as manchas solares não são resultantes de explosões na fotosfera, como havia afirmado anteriormente. Uma evidência clara disso, talvez tenha ocorrido em decorrência das observações das explosões solares (proeminências na cromosfera com o filtro hidrogênio-alfa) e do Sol por projeção (que não apresentou manchas solares) durante o curso, mostrando que as proeminências, nem sempre estão ligadas à presença de manchas solares.

Os alunos que responderam no questionário inicial que a superfície solar é parecida com a da Lua, provavelmente foram influenciados por conhecimentos prévios do Contexto Pessoal, onde estudaram que a Terra e a Lua possuem crateras. Já os que descreverem a superfície solar, como sendo quente com magma e vulcões, também apresentaram concepções ingênuas influenciadas por seus conhecimentos e experiências prévias, nos quais aplicaram conhecimentos de geologia a um corpo pouco conhecido, o Sol. Por fim, os alunos que responderam que a superfície solar é composta por gases, provavelmente foram influenciados por interesses prévios do Contexto Pessoal em que buscaram saber mais sobre o tema ao visitarem o Observatório, lerem livros e sites de Astronomia ou terem assistido a documentários sobre o tema.

O Contexto Pessoal, em especial os conhecimentos prévios do aluno T. do segundo ano, sobre explosões nucleares, o levaram a acreditar que seria possível observar explosões 
nucleares no Sol, assim como se observou bombas atômicas explodindo na superfície terrestre. Ele desconhecia o fato de que as reações nucleares ocorrem no interior das estrelas, sendo, portanto, impossíveis de serem observadas com o uso de um telescópio. A aluna F. do terceiro ano, que esperava observar "nuvens de gás e poeira" , provavelmente usou o termo pensando que seria a constituição do Sol, uma vez que é a partir de nuvens de gases e poeira é que se originou o Sistema Solar. Este termo é bastante divulgado em livros e documentários de Astronomia ao descrever o surgimento de estrelas e planetas. O conhecimento da aluna foi provavelmente influenciado por seus conhecimentos e interesses prévios do Contexto Pessoal.

A concepção de que as manchas solares seriam estrelas passando na frente do Sol, apresentada pela aluna I. provavelmente sofreu influência de seus conhecimentos prévios do Contexto Pessoal onde sua idéia, talvez tenha surgido da concepção de um Sistema Solar, com estrelas em seu interior e que as mesmas poderiam passar na frente do Sol, uma visão reforçada por alguns livros didáticos, como discutido no capítulo anterior. As alunas que sabiam que o Sol é gasoso assumiram que as manchas solares seriam regiões com uma composição química distinta das demais do Sol. Tais alunas apresentaram um conhecimento menos ingênuo que seus colegas que esperavam observar lava, magma ou buracos no Sol, e aplicaram seus conhecimentos prévios de que o Sol é gasoso para tentar explicar o que são as manchas solares.

O aluno Wi. por sua vez, é um entusiasta em Astronomia portanto, já havia lido muito material sobre o assunto e se destacou em relação aos seus colegas do curso. Tal aluno possui seus interesses prévios do Contexto Pessoal como fator determinante e é guiado por sua motivação sobre o assunto.

As respostas ao questionário inicial também sofreram uma forte influência do Contexto Sócio-Cultural, uma vez que a professora ao divulgar o curso já havia dito que os alunos observariam manchas solares e "explosões" com o objetivo de os atrair para o curso que seria oferecido.

Os alunos que responderam no questionário e entrevistas finais que as manchas solares são regiões mais frias da superfície solar devido ao campo magnético do Sol provavelmente 
foram influenciados pelo Contexto Físico após observarem o Sol pelos telescópios e verem o eletroimã funcionando. Após as observações pelos telescópios, houve discussões sobre a natureza das manchas solares e proeminências, ou seja, o Contexto Sócio-Cultural, também desempenhou um papel importante em suas respostas.

A aluna I. do segundo ano, que havia escrito que as manchas solares são estrelas passando na frente do Sol, no questionário final, respondeu corretamente que as manchas solares são regiões mais frias da fotosfera devido à presença de campos magnéticos mais fortes. Ou seja, neste caso, a concepção realista de que as manchas solares são estrelas evoluiu para uma concepção mais abstrata, devido aos três contextos, o Pessoal, o Físico e o Sócio-Cultural. O Contexto Físico foi importante, pois permitiu à aluna que observasse imagens de manchas solares por telescópios, ou mesmo por imagens de sondas espaciais exibidas durante o curso. Tais imagens possibilitaram que aluna notasse que as manchas solares não possuem o mesmo formato de estrelas que vemos a noite. O Contexto SócioCultural, por meio de discussões sobre a natureza das manchas solares foi provavelmente um fator decisivo na resposta da aluna ao concluirmos que as manchas solares possuem uma natureza magnética. Por fim, a motivação sobre o tema e interesses prévios do Contexto Pessoal da aluna facilitaram a aprendizagem da mesma sobre a constituição das manchas solares.

\subsubsection{Estimativa da temperatura na fotosfera solar}

Quando perguntado no questionário inicial como é a superfície solar, a maior parte dos alunos respondeu que é quente, mais quente do que qualquer coisa que existe na Terra; apenas o aluno Wi. do terceiro ano acrescentou em sua resposta, que a temperatura é de aproximadamente $6000 \mathrm{~K}$. Em seguida, foi explicado aos alunos que iríamos realizar uma atividade para estimar a temperatura na superfície solar, mas que para tanto seria necessário sabermos alguns conceitos de corpo negro e calorimetria. Tais conceitos foram explicados e discutidos antes da realização da atividade, que integrou noções de calorimetria, física moderna e astrofísica usando materiais de baixo custo como uma lata, um termômetro, um cronômetro e um dia ensolarado (CANIATO, 1990). A atividade faz 


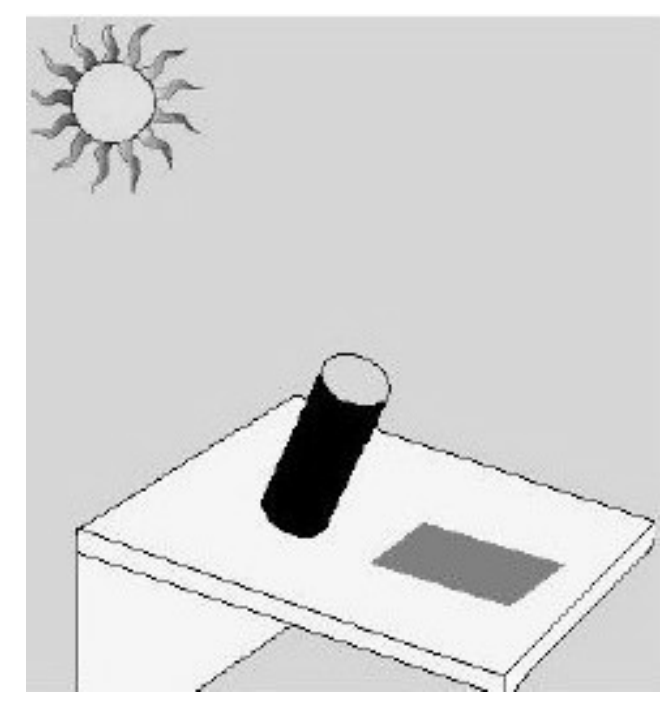

Figura 23 - Posição da lata exposta ao Sol. É importante certificar-se de que a lata projete uma sombra retangular para permitir que os raios de luz atinjam sua superfície. Fonte: http: //educar.sc.usp.br/experimentoteca/fisica/kit3_calorimetria/exp6_termo.pdf

parte da experimentoteca do CDCC, que fornece kits para as escolas realizarem experimentos didáticos de ciências (SCHIEL; FREITAS, 2005).

Uma lata cilíndrica preta cheia de água exposta ao Sol pode ser considerada um corpo negro (figura 23). Neste experimento, a lata foi exposta ao Sol por aproximadamente cinco minutos (cronometrados pelos alunos). A fração de radiação que atingiu a lata é proporcional à radiação emitida pelo Sol na distância Terra-Sol.

A energia total irradiada pelo Sol:

$$
E_{T}=\frac{E_{\text {lata }} A}{A_{\text {lata }}}
$$

Onde A corresponde à àrea de uma esfera com o raio igual à distância da Terra ao Sol ( $\mathrm{R}=$ distância da Terra a o Sol) dado por:

$$
A=4 \pi R^{2}
$$

Neste experimento, enchemos a lata com água, para que fosse possível medir a variação de temperatura da água antes e depois de exposta ao Sol. Com estes dados e a massa de água dentro da lata e o calor específico da água podemos calcular a energia solar absorvida pela lata $\left(E_{\text {lata }}\right), \mathrm{A}_{\text {lata }}$ é a área longitudinal da lata (diâmetro multiplicado pela altura da 
lata) pode ser visto na figura 24. A energia recebida pela água na lata é:

$$
E_{\text {lata }}=m c\left(T_{f}-T_{i}\right)
$$

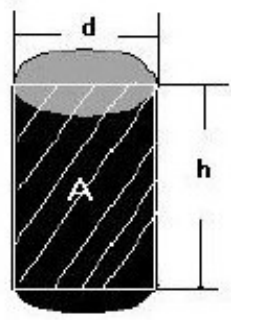

Figura 24 - Área longitudinal da lata, (dxh). Fonte: http://educar.sc.usp.br/ experimentoteca/fisica/kit3_calorimetria/exp6_termo.pdf

onde $\mathrm{m}$ e c são respectivamente, a massa de água e o calor específico, $\mathrm{T}_{\mathrm{i}}$ e $\mathrm{T}_{\mathrm{f}}$ são as temperaturas antes e após a lata ser exposta ao Sol.

Os próximos passos foram calcular a potência irradiada pela superfície do Sol por unidade de área $(\mathrm{P})$ e com isto obter a temperatura na fotosfera solar. Para tanto a energia absorvida pela lata foi dividida pelo tempo que a mesma foi exposta ao Sol, de maneira a obtermos a potência. Considerando o Sol como um corpo negro usamos a lei de Stephan-Boltzmann para obter a temperatura na fotosfera $(\mathrm{T})$ :

$$
P=\sigma T^{4}
$$

onde $\sigma$ é dado por $\sigma=5,67 \times 10^{-8}\left(W / m^{2} K^{4}\right)$.

Ao concluir a atividade os alunos obtiveram a potência irradiada pelo Sol como $P=$ $3,7 \times 10^{26} \mathrm{~W}$ e a dividiram pela área do Sol (raio do Sol é de aproximadamente $695500 \mathrm{Km}$ ) para aplicar a lei de Stephan-Boltzmann (equação 7) e obter a temperatura da fotosfera solar, o valor obtido foi $\mathrm{T}=5720 \mathrm{~K}$. Os valores calculados para a superfície solar estavam na mesma ordem de grandeza da temperatura de referência para a fotosfera $(5780 \mathrm{~K})$ (SILVA, 2006). Este resultado depende muito do local onde a experiência é realizada, uma vez que as condições atmosféricas podem interferir.

Uma informação adicional que foi compartilhada com os alunos foi que a temperatura na superfície de uma estrela está ligada à sua cor. Estrelas frias (3000 a 4000 K) são 
geralmente vermelhas, enquanto que estrelas mais quentes (acima de $8000 \mathrm{~K}$ ) são azuis, o Sol com uma temperatura na fotosfera de $5800 \mathrm{~K}$ é uma estrela amarela, mais informações podem ser obtidas em ZEILIK (1997).

No questionário final quando perguntados sobre como é a superfície solar, alguns alunos responderam que é quente com uma temperatura de aproximadamente 5800 K. Nenhum aluno respondeu com um valor muito acima, ou muito abaixo dos estimados na atividade.

O Contexto Físico (FALK; DIERKING, 2000) influenciou no cálculo da potência irradiada pelo Sol e na temperatura da fotosfera, quando os alunos manipularam termômetros, cronômetros e outros materiais da atividade. Ao mesmo tempo, o Contexto Sócio-Cultural também foi importante na medida em que trocaram experiências, tentativas e comentários sobre o experimento que realizaram.

Conceitos importantes de corpo negro e calorimetria quando ensinados em sala de aula, muitas vezes, não passam de conhecimentos vagos que o aluno não é capaz de conectar com sua realidade, fazendo com que os mesmos se tornem irrelevantes e sem graça. Esta atividade permitiu contextualizar o ensino de importantes aspectos de física moderna e calorimetria mostrando aos alunos a relevância dos mesmo quando aplicados na estimativa da potência irradiada pelo Sol e da temperatura da fotosfera a partir de equipamentos de fácil acesso e baixo custo. Além disso, a conclusão da atividade permitiu, ainda discutir um pouco de evolução estelar, relacionando a temperatura na superfície da estrela com sua cor.

\subsubsection{Produção de energia solar}

Todos alunos afirmaram, no questionário inicial, que o Sol produz sua própria energia. Duas alunas, J. do primeiro ano e C. do segundo ano afirmaram que o Sol produz energia pela emissão de seus raios e calor. Alguns alunos especificaram, no questionário inicial, que a forma de produção de energia solar é a fusão nuclear. Mas, houve o caso o do aluno T. do segundo ano que escreveu no questionário inicial e final que o Sol produz energia pela fusão e fissão nucleares. Em se tratando de onde ocorrem as reações nucleares no Sol, o aluno V. do primeiro ano afirmou no questionário inicial que ocorrem na superfície 
solar, o aluno provavelmente acreditou que as proeminências solares seriam responsáveis pela produção de energia no Sol.

A aluna F. do terceiro ano escreveu que a fonte da energia solar é a queima de gases, outro aluno, We. do terceiro ano escreveu que o Sol produz energia por reações que ocorrem com a queima do gás hélio, mas ambos não especificaram como ocorre esta "queima" e quais seriam os gases envolvidos. Eles provavelmente acreditavam que o Sol produziria energia por combustão, já que usaram o termo "queima" em suas respostas ao questionário inicial.

O aluno L. do segundo ano escreveu que o Sol produz energia "pelo consumo de elementos químicos, ocasionando pequenas explosões nucleares que liberam energia ". Como este aluno escreveu "pequenas explosões" ele provavelmente estava se referindo às proeminências e não às reações de fusão nuclear, como fonte de energia solar, assim como no caso do aluno $\mathrm{V}$. do primeiro ano.

A aluna Ta. do segundo ano respondeu que o Sol produz energia pelo consumo do hidrogênio e do hélio por meio de explosões, sem especificar que são reações nucleares. A aluna, provavelmente desconhecia a fusão nuclear que transforma elementos mais leves como o hidrogênio em elementos mais pesados, como o hélio. Apenas o aluno Wi. do terceiro ano afirmou que o processo de produção de energia do Sol é a fusão nuclear que converte o hidrogênio em hélio no interior do Sol.

Novamente, temos concepções bastante variadas, desde concepções ingênuas de que a produção de energia solar seria por meio de seus raios, até concepções mais próximas às científicas em que ocorreria por processos de fusão nuclear.

A concepção ingênua de que o Sol emite energia por seus raios, provavelmente advém de conhecimentos prévios do Contexto Pessoal obtidos a partir de representações pictóricas usuais do Sol que mostram a luz emitida na forma de raios radiais. Além disso, as experiências prévias do Contexto Pessoal, provavelmente influenciaram suas respostas, pois ao olharmos para o Sol e outras estrelas temos a impressão que estão emitindo raios. Os alunos que assumiram que a produção de energia no Sol ocorreria da mesma maneira que uma das principais fontes de energia na Terra, a combustão foram influenciados por 
experiências prévias do Contexto Pessoal ao responderem à questão. Por fim, os alunos que sabiam que o Sol é composto por hidrogênio e hélio e que produz energia por fusão nuclear foram influenciados por interesses prévios e motivação do Contexto Pessoal.

Durante as discussões sobre o processo de produção de energia solar apresentamos as principais hipóteses históricas de produção de energia no Sol, por meio de slides em apresentação de Power Point (informações contidas nos slides estão no apêndice A ), outros pontos apresentados aos alunos foram os principais processos de transporte de energia dentro do Sol, a convecção e a irradiação. Esta parte do curso Física Solar teve poucos comentários dos alunos, uma vez que todas as perguntas feitas pela professora durante as apresentações foram respondidas pelo aluno Wi. A professora, notando que apenas o aluno Wi. respondia às questões levantadas, pediu a ele que deixasse que seus colegas respondessem às perguntas, mas os mesmos permaneceram em silêncio, já que sabiam que o aluno Wi. logo responderia.

No questionário final, a aluna C. do segundo ano, que havia respondido que o Sol produz energia por seus "raios", escreveu no questionário final que o principal processo envolvido na produção de energia solar é a fusão de hidrogênio, mas acrescentou em sua resposta, que para isto ocorrer seria necessário uma temperatura elevadíssima de 5000 de graus C. Ela provavelmente não compreendeu, que a produção de energia ocorre no interior das estrelas (no caso do Sol, a uma temperatura de aproximadamente 15 milhões de graus C), e não em sua superfície, já que citou uma temperatura próxima à da fotosfera. A aluna J. do primeiro ano, que também havia escrito no questionário inicial que a forma de produção de energia solar são seus raios, escreveu no questionário final que precisa haver campo magnético, onde a aluna descreveu como sendo átomos ionizados em movimento que produzem a energia solar. Ela confundiu a origem das manchas solares, o campo magnético, com a origem da energia produzida pelo Sol, a fusão nuclear.

As respostas de ambas as alunas contêm informações que foram discutidas durante o curso, como a temperatura na superfície solar (5800 K), fusão do hidrogênio e o campo magnético solar. O curso Física Solar, apresentou muitos conceitos novos, como campo magnético solar, fusão nuclear, fotosfera, cromosfera, proeminências dentre outros. Devido 
ao curto intervalo de tempo em que se o curso se passou (5 dias) é natural que as alunas não tenham tido tempo de amadurecer os novos conhecimentos ensinados.

No questionário final o aluno V. do primeiro ano, que havia respondido no questionário inicial que a produção de energia ocorre por explosões na superfície solar, somente escreveu que o Sol produz energia por fusão nuclear, sem especificar que ocorre no núcleo. O aluno L. do segundo ano, que havia escrito no questionário inicial, que o Sol produz energia pelo consumo de elementos químicos, por pequenas explosões nucleares que liberam energia, afirmou no questionário final, que a fonte de energia solar é "a fusão nuclear, onde há a junção de núcleos de átomos do Sol e colisões entre esses núcleos". O aluno compreendeu que a fonte de energia do Sol é a fusão nuclear, mas também, não especificou se ocorre no núcleo ou na fotosfera solar.

A aluna Ta. do segundo ano compreendeu que o processo de produção de energia do Sol resulta da fusão de hidrogênio em hélio, e não do consumo do hidrogênio e do hélio por meio de explosões, como havia respondido no questionário inicial. Ela ainda acrescentou, no questionário final, conhecimentos que foram ensinados no curso de que o Sol, no futuro irá transformar o hélio em um elemento químico mais pesado e que as explosões solares seriam de fato as reações nucleares, responsáveis pela produção de energia no Sol.

Podemos afirmar pelas respostas dos alunos ao questionário final que as discussões realizadas durante o curso, ou seja, o Contexto Sócio-Cultural influenciou suas respostas ao questionário final, na medida em que muitos apresentaram concepções mais próximas às aceitas pela comunidade científica, ao deixarem por exemplo, de mencionar o termo "queima" que se refere à combustão em suas respostas, pois foi discutido durante o curso que esta foi uma hipótese aceita até o século XVIII.

\subsubsection{Observação do espectro solar no visível}

Foi perguntado aos alunos, no questionário inicial ( apêndice D ), o que eles esperavam observar no espectro solar. Pelas suas respostas ao questionário ficou claro que alguns (4 alunos) não faziam idéia do que é um espectro, pois afirmaram que observariam detalhes da superfície solar, como a aluna J. do primeiro ano que escreveu, "quero ver se o Sol tem 
buracos mesmo". Alguns alunos esperavam observar no espectro solar cores do arcoíris, demonstrando assim, um certo conhecimento sobre o assunto, outros foram mais além, ao afirmarem que observariam a composição do Sol no espectro solar. O aluno Wi. do terceiro ano, apresentou uma resposta mais completa e próxima do que seria observado no curso, ao desenhar o espectro solar com linhas escuras, que identificou como sendo os elementos químicos presentes no Sol.

O aluno We. do terceiro ano, por sua vez, afirmou que esperava observar a região do ultravioleta, raios $\mathrm{X}$, raios gama etc. Sua resposta mostrou que ele possuía uma certa noção do que é um espectro eletromagnético. Com isto, esperava observar todo o espectro solar, apresentando um desconhecimento dos métodos nos quais detectamos os espectros das estrelas e outros objetos. Assim, não sabia que seria impossível observar todo o espectro do Sol da superfície da Terra, pelo fato de a atmosfera terrestre barrar a maior parte dos comprimentos de onda do espectro eletromagnético e nossos olhos serem incapazes de detectá-los.

Outra pergunta do questionário inicial foi se há elementos químicos no Sol, e como sabemos disto sendo que nunca fomos até lá. A aluna, C. do segundo ano respondeu que há elementos químicos no Sol e sabemos disso estudando seus raios. A aluna, provavelmente estava se referindo à luz solar, e que a mesma forneceria as informações necessárias para se determinar o que existe no Sol. A aluna R. do primeiro ano escreveu que a radiação solar é um elemento, em suas palavras, "sim, elementos como a radiação solar, atravez de alguns instrumentos é possivel captar essa radiação." A aluna, provavelmente não compreendia a diferença entre elemento químico e radiação e possivelmente estava se referindo ao telescópio, ao escrever alguns instrumentos capazes de captar a radiação solar. O que é natural, uma vez que estes assuntos são tratados superficialmente na escola.

Outro aluno, V. do primeiro ano afirmou que o Sol possui gases que o rodeiam e que é possível saber quais elementos existem no Sol através de explosões observadas por satélites. O aluno possivelmente acreditou que o Sol teria uma composição homogênea, ou seja, seu núcleo teria a mesma composição química que sua atmosfera, produzindo a mesma radiação no núcleo e em sua superfície. Assim, poderíamos saber a composição 
interna do Sol, estudando a externa.

Os demais alunos mencionaram que o Sol é rico em hélio e/ou hidrogênio, mas suas justificativas de como sabemos isto foram bastante diversificadas. Como a aluna do terceiro ano, F., escreveu que o Sol possui apenas hidrogênio e hélio justificando que é porque são os únicos gases inflamáveis e são abundantes.

Uma justificativa confusa foi a de We. do terceiro ano, ao escrever que o Sol deve possuir muitos elementos, como o hélio e magma, porque ele é responsável pela fotossíntese e portanto, a luz solar contém vários materiais. O aluno We., assim como a aluna R. do primeiro ano confundiram elementos químicos, com a radiação eletromagnética. Outra confusão foi denominar o composto magma de elemento químico, como se o mesmo existisse na tabela periódica. Esta concepção ingênua, provavelmente indica que o aluno We. acreditou que o Sol forneceria os elementos químicos irradiando luz, que seria então, absorvida pelas plantas durante o processo de fotossíntese.

Já, o aluno T. do segundo ano afirmou que deve haver praticamente todos os elementos químicos no Sol, uma vez que o Sol é capaz de fazer fissão e fusão nuclear. A resposta deste aluno mostra que o mesmo sabia que os elementos químicos são sintetizados nas estrelas, mas desconhecia os processos envolvidos na produção de elementos químicos no interior do Sol ( mais informações no apêndice A). Os alunos, T. do segundo ano e Wi. do terceiro ano afirmaram no questionário inicial, que existem elementos como o ferro no Sol e que os mesmos são conhecidos devido à técnica de espectroscopia.

Julgamos relevante discutir sobre a existência de outras radiações emitidas pelo Sol, além do visível, a fim de mostrar que o visível é somente uma parte muito pequena do espectro eletromagnético e que estudando a radiação solar em outros comprimentos de onda extraímos informações relevantes sobre o Sol que não são obtidas na região do visível. Para sabermos as concepções dos alunos a respeito de outros comprimentos de onda perguntamos no questionário inicial se o Sol emite apenas luz visível. Todos responderam que não, afirmando que emite outras " radiações ", " raios " e ainda, "luzes invisíveis ". A aluna C. do segundo ano respondeu "o sol também emite raios invisíveis que ficam na atmosfera." O aluno V. do primeiro ano escreveu: "o Sol emite uma grande variedade de 
luzes, porém muitas delas, não são visiveis para o ser humano." Houve também respostas como de P. e R., ambos do primeiro ano, que afirmaram que além do visível, o Sol emite calor e radiações solares. Os demais alunos afirmaram que o Sol emite além do visível, ultravioleta, calor e alguns citaram outros tipos de radiações, como raios X, raios gama e ondas de rádio. O aluno Wi. do terceiro ano apresentou a resposta mais completa ao afirmar que o Sol se aproxima bastante de um corpo negro, que por definição emite em todos os comprimentos de onda.

A aluna C. do segundo ano não se ateve ao fato de que a radiação emitida pelo Sol, como o infravermelho, visível e uma faixa do ultravioleta atingem a superfície terrestre. Ela provavelmente não associou o calor como sendo um dos raios invisíveis, nem o fato de usarmos filtro solar para nos proteger da emissão de raios ultravioleta (outra radiação invisível), pois escreveu que os raios invisíveis ficam na atmosfera.

A atividade mais interessante para o ensino médio foi a observação do espectro solar, conforme foi constatado nas respostas ao questionário final de opinião (apêndice E). Antes de se observar o espectro solar, os estudantes manipularam os principais componentes de um espectroscópio e ensinamos como prismas e redes de difração produzem os fenômenos físicos básicos como refração, reflexão e difração. Para que compreendessem que a espectroscopia é uma ferramenta útil na extração de informações a respeito da composição química de objetos celestes, solicitamos que desenhassem e descrevessem verbalmente, para seus colegas e para a professora, o espectro produzido por lâmpadas de mercúrio, incandescente, fluorescente e de hélio, enquanto as observavam pelas redes de difração. Após reconhecerem a existência de diversos padrões de linhas brilhantes em cada tipo de lâmpada, pedimos para que identificassem a lâmpada observada comparando suas observações, com um quadro espectral da sala solar.

Durante a discussão sobre prismas e redes de difração perguntamos aos alunos o que eles esperavam observar no espectro de uma lâmpada. Abaixo temos um trecho do diálogo entre a professora e os alunos, evidenciando que os mesmos tinham uma noção do que iriam observar.

Prof: Se eu ligar uma lâmpada e olhar por uma rede o que será que vou 
ver? Se eu observar lâmpadas diferentes será que vou ver coisas diferentes?

Aluna C. do segundo ano: Vai ser diferente porque cada lâmpada tem elementos distintos.

Prof: O que você espera ver de diferente?

Aluna C. do segundo ano: Determinadas cores que vão absorver.

Prof: Vai ter absorção?

Aluna C. do segundo ano: do quente vai para um lugar mais frio.

Prof: Tem gás frio na lâmpada?

Aluna C. do segundo ano: vai ser de emissão.

Prof: Vai ter linhas escuras?

Aluna C. do segundo ano: brilhantes

Prof: Todas as lâmpadas aqui em cima vão ter linhas de emissão?

Silêncio dos alunos

Prof: Será que as linhas vão estar na mesma posição em lâmpadas diferentes?

Aluna I. do segundo ano: não

Prof: E como posso ter certeza, por exemplo, que uma determinada lâmpada é de mercúrio?

Aluna I. do segundo ano: observando as linhas.

Aluno T. do segundo ano: comparar com um padrão.

Foi exatamente o que fizemos. A primeira lâmpada observada foi a incandescente, apresentando um espectro sem linhas brilhantes, apenas com um contínuo, já que é resultado do aquecimento do filamento de tungstênio que emite em muitas frequiências produzindo um contínuo. Em seguida, após desenharem e discutirem o que estava sendo observado apontaram suas redes para uma lâmpada fluorescente, contendo algumas linhas brilhantes no azul e no verde e bandas no amarelo e no vermelho. Eles perceberam as diferenças entre o espectro da lâmpada fluorescente e da incandescente, como pode ser visto na figura 25 desenhada pela aluna J. do primeiro ano.

Pedimos para que apontassem suas redes para uma lâmpada de mercúrio do kit e para 


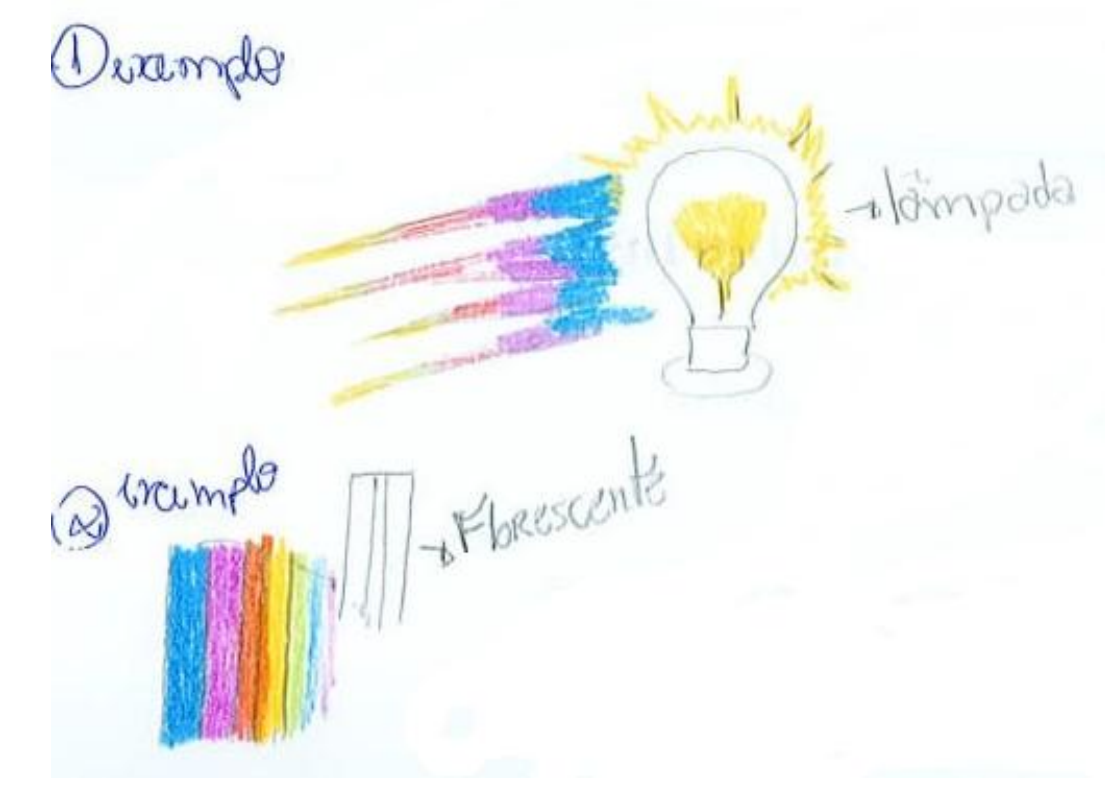

Figura 25 - Desenho da aluna J. do primeiro ano representando os espectros das lâmpadas incandescente e fluorescente observadas durante o curso.

outra lâmpada de mercúrio do teto, sem informá-los de que as lâmpadas continham o mesmo gás. Ao fazerem isto, perceberam que em ambos os espectros havia as mesmas linhas nas mesmas posições. A partir daí discutimos que tais linhas são uma indicação do que existe dentro das lâmpadas, ou seja, neste caso, ambas lâmpadas possuem o gás mercúrio em seu interior. Em seguida, identificaram as linhas de outra lâmpada desconhecida, que descobriram tratar-se da lâmpada de hélio. Na figura 26 podemos ver o desenho do espectro da lâmpada de mercúrio e de hélio da aluna J. Em geral, os alunos tiveram dificuldade em se aterem às linhas de emissão, uma vez que as cores do contínuo prendiam sua atenção.

Para se observar o espectro solar usamos um telescópio fixo na vertical, heliostato (figura 5 do capítulo 4) e uma montagem espectroscópica do tipo Littrow (figura 9 do capítulo 4), conforme descrito no capítulo 4. Projetamos o espectro solar na parede, ao observá-lo atentamente, perceberam que além das cores do arcoíris havia, também linhas escuras (figura 27). Os estudantes ficaram surpresos em observar linhas escuras ao invés de linhas brilhantes como haviam visto no caso das lâmpadas. Isto gerou uma discussão do porque das linhas espectrais serem escuras, enquanto que as linhas das lâmpadas são brilhantes. Após observarem e identificarem o espectro das lâmpadas os estudantes 


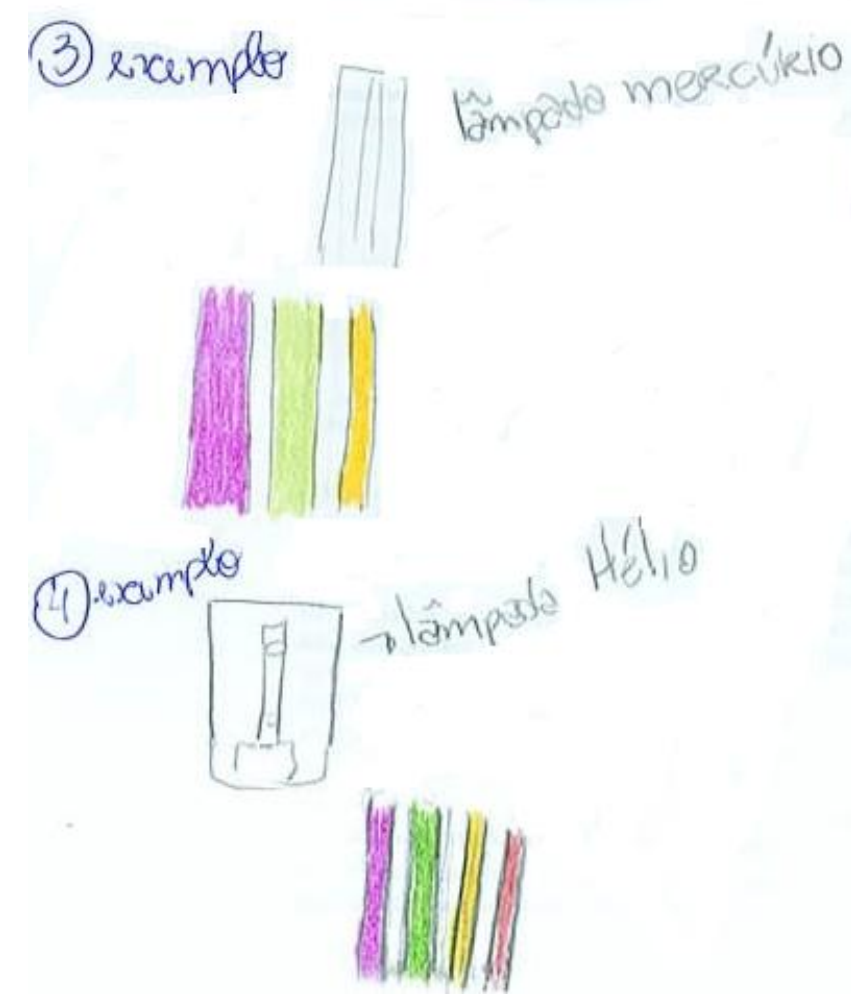

Figura 26 - Desenho da aluna J. do primeiro ano mostrando o espectro de uma lâmpada de mercúrio e de hélio observadas no curso.

compreenderam que as linhas do espectro solar estão relacionadas aos elementos químicos presentes no Sol. O passo seguinte foi identificar algumas das linhas do espectro solar usando o quadro espectral (figura 36 do capítulo 4). Pelo quadro espectral foi possível afirmar que duas das linhas escuras observadas eram de fato bandas de oxigênio da atmosfera terrestre e não do Sol. As linhas de absorção do Sol são; o ferro, sódio, magnésio, hidrogênio e outros elementos químicos de sua atmosfera. Para auxiliar os alunos no entendimento dos motivos pelos quais as linhas do espectro solar são escuras, discutimos as três leis de Kirchoff (apêndice A) .

Como os alunos já haviam estudado no curso sobre a estrutura do Sol (núcleo e atmosfera) foram encorajados a aplicarem as Leis de Kirchoff para compreenderem os motivos pelos quais o espectro solar tem linhas escuras. Com a mediação da professora, os estudantes foram capazes de compreender que o núcleo do Sol age como um corpo negro, que emite um espectro contínuo. A atmosfera solar como está a uma temperatura bem abaixo do núcleo, absorve a radiação do mesmo produzindo as linhas escuras do espectro solar. Além disso, os alunos foram informados no curso sobre a existência de linhas de absorção 


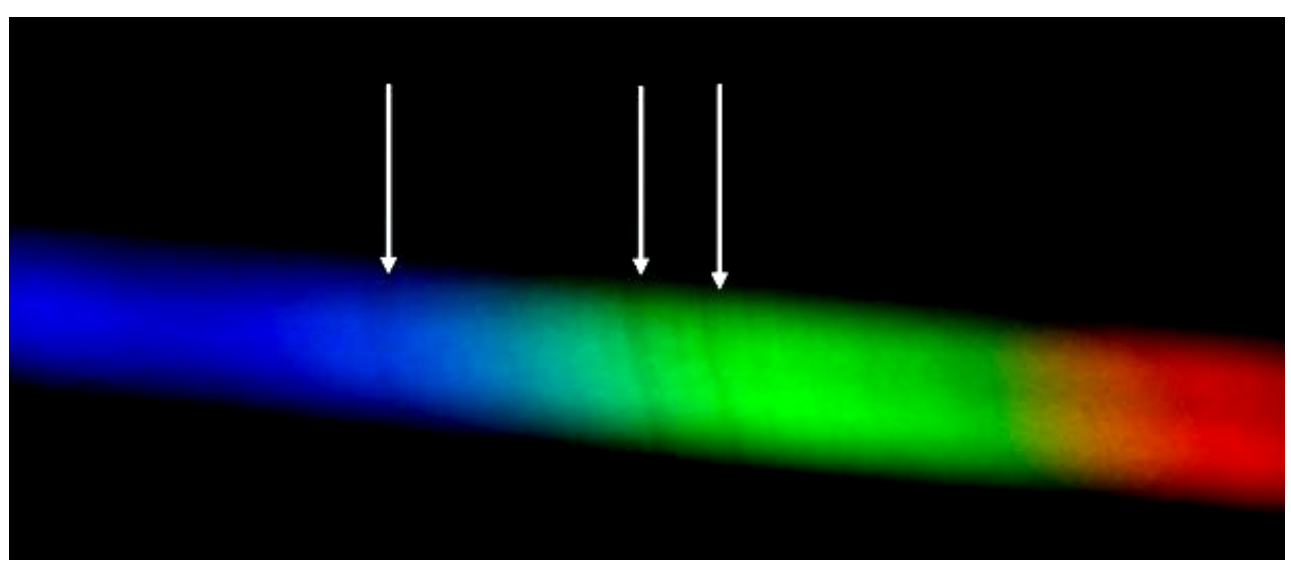

Figura 27 - Espectro solar obtido no Observatório Astronômico do CDCC/USP mostrando algumas linhas espectrais de Fraunhofer.

no Sol em outras faixas espectrais e da presença de linhas emissão em algumas estrelas (mais quentes que o Sol) e nebulosas.

Abaixo temos um trecho da discussão entre a professora e os alunos sobre a existência de transições eletrônicas (linhas espectrais) na região do ultravioleta:

Prof: Se a gente pudesse observar o espectro solar no U.V., lá teria linhas de carbono e o oxigênio. Estas linhas estariam na mesma posição das linhas no espectro no visível?

Aluna I. do segundo ano: não

Aluno Wi. do terceiro ano: Porque seriam outras linhas teria linhas no U.V., mas não seriam as mesmas linhas do visível.

Prof: Por que cada elemento tem um conjunto de linhas e não apenas uma linha?

Aluno Wi. do terceiro ano: Porque há vários níveis atômicos para os elétrons saltarem.

Aluna C. do segundo ano: Ele salta apenas em determinadas energias.

Prof: Isso, assim o carbono e os demais elementos possuem transições eletrônicas em diferentes freqüências do espectro.

Este diálogo mostrou que os alunos de fato compreenderam que as linhas espectrais são transições eletrônicas em energias específicas do átomo que podem ocorrer em várias 


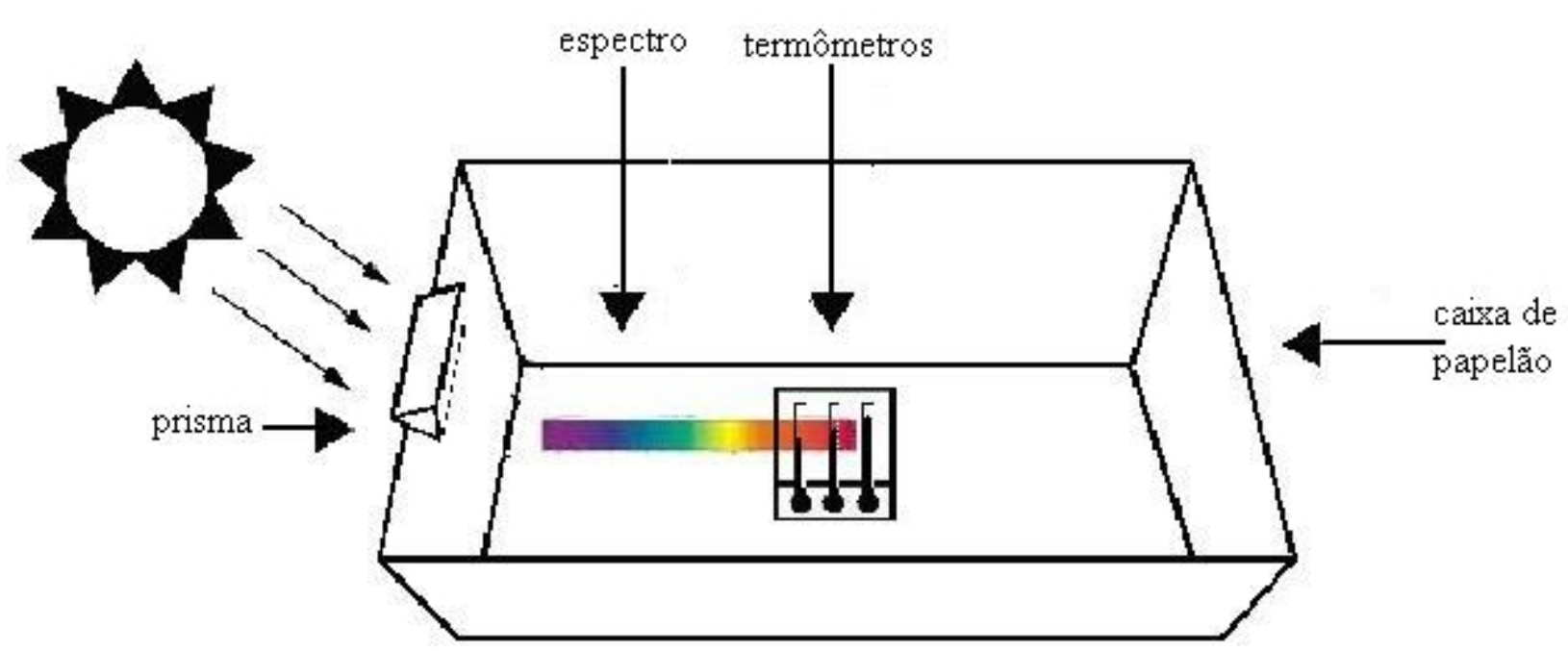

Figura 28 - Ilustração do experimento da descoberta do infravermelho de Herschel.

regiões do espectro e que cada elemento químico possui suas próprias transições características.

A última prática experimental teria como objetivo ilustrar como foi feita historicamente a descoberta de que o espectro solar possui outras radiações além do visível. Para isto, desenvolvemos um experimento inspirado na descoberta do infravermelho de William Herschel (1738-1822) em 1800 (figura 28). Ele colocou termômetros no espectro solar, fixando, um termômetro no vermelho, outro no azul e outro no amarelo. Após alguns minutos, fez a leitura dos termômetros e notou que o vermelho estava mais quente que os outros dois termômetros. A partir daí, colocou outro termômetro além do vermelho e percebeu que sua leitura foi superior ao do termômetro no vermelho. Concluindo então, que o espectro solar não termina no vermelho, ou seja, o Sol emite outras radiações, como o infravermelho (CHESTER, 1999). No entanto, devido ao mau tempo não foi possível realizar este experimento com os alunos, mas comentamos sobre ele.

Todos alunos afirmaram no questionário final que observaram no espectro solar, linhas escuras e alguns mencionaram o contínuo de cores. Quando perguntados no questionário final, quais materiais foram necessários para se observar o Sol, eles responderam espectroscópio, fenda, espelhos, telescópio, anteparo, rede de difração, sem especificar que a fenda e a rede de difração fazem parte do espectroscópio e que os espelhos fazem parte 
do heliostato.

Em relação à questão do questionário final sobre quais elementos químicos estão presentes no Sol, nenhum aluno apresentou a concepção inicial de que a radiação solar é um elemento químico, ou mesmo mencionou o termo "raios solares". Isto provavelmente ocorreu porque os alunos observaram o espectro solar e identificaram os principais elementos presentes concluindo que são os mesmos elementos químicos existentes na Terra.

O aluno V. do primeiro ano que havia escrito no questionário inicial que é possível saber quais elementos estão presentes no Sol devido às explosões observadas por satélites, no questionário final afirmou, que sabemos da existência de outros elementos no Sol como o ferro, devido à provável existência de estrelas anteriores ao Sol que seriam mais massivas que ele, mas não se referiu à técnica de espectroscopia. No curso foi mencionado que devem ter existido uma ou duas estrelas anteriores ao Sol, que seriam responsáveis pela síntese dos elementos químicos mais pesados do que o hidrogênio e o hélio presentes no Sistema Solar, mas esta teoria só foi criada a partir do momento que se soube, por espectroscopia, da existência de elementos mais pesados no Sol.

O aluno We. do terceiro ano afirmou no questionário final que há vários elementos no Sol como o hélio e o dióxido de carbono que foram detectados por espectroscopia. O aluno não se ateve à definição de molécula e elemento químico, escrevendo que o dióxido de carbono é um elemento quando de fato é uma molécula. Não há dióxido de carbono na região visível do espectro solar, o que existe são bandas de oxigênio que pertencem a nossa atmosfera. Este aluno, provavelmente manteve sua concepção prévia de que a radiação solar seria responsável por fornecer elementos químicos para as plantas durante a fotossíntese, uma vez que mencionou o dióxido de carbono, fonte da respiração das plantas. Os demais alunos responderam que há vários elementos químicos no Sol e que sabemos sua constituição por espectroscopia, mas apenas os alunos Wi. do terceiro e Ta. do segundo ano mencionaram como isto é feito.

Perguntamos no questionário final, o que são as linhas espectrais observadas no Sol e nas lâmpadas, e porque as do Sol são escuras e as das lâmpadas brilhantes. Todos alunos que responderam à questão, afirmaram que as linhas brilhantes das lâmpadas são de 
emissão e as linhas escuras no Sol são de absorção. De uma maneira geral compreenderam que as linhas do espectro solar são escuras devido ao fato de o núcleo solar ser mais quente que a superfície, e que a mesma absorve a radiação oriunda do interior solar. O aluno V. ainda acrescentou no questionário final, que existem linhas escuras no espectro solar causadas pela nossa atmosfera. Três alunos deixaram a questão em branco, provavelmente porque o tempo de responder ao questionário final foi insuficiente.

Apenas o aluno We. do terceiro escreveu no questionário final que as linhas brilhantes no espectro das lâmpadas são "cores que significam a identificação de algum composto químico e as linhas escuras são os elementos químicos ." O aluno não compreendeu o que de fato são as cores no fundo do espectro das lâmpadas e do Sol, e com isto, provavelmente não entendeu o significado das linhas espectrais como sendo transições eletrônicas.

Quando perguntado às alunas C. do primeiro ano e I. do segundo ano, nas entrevistas finais, se as linhas do hidrogênio no espectro solar se encontram na mesma posição das linhas de uma lâmpada de hidrogênio, ambas responderam que sim indicando que compreenderam o significado das linhas espectrais das lâmpadas e do Sol.

No questionário final foi perguntado quais radiações o Sol emite além do visível. Todos alunos afirmaram que o Sol emite em todos comprimentos de onda.

Os alunos que associaram o espectro solar com as cores do arcoíris, provavelmente aprenderam esta relação em livros didáticos, ou seja, graças a seus conhecimentos prévios e experiências do Contexto Pessoal (FALK; DIERKING, 2000) ao verem o desenho de um prisma decompondo a luz solar, que é responsável pelo mesmo fenômeno que produz o arcoíris, a refração. Já os alunos que escreveram que seria possível observar a composição do Sol, provavelmente foram influenciados por interesses prévios do Contexto Pessoal obtidos em livros de Astronomia, visitas ao Observatório, assistindo a documentários sobre o tema, ou ainda, por sites de Astronomia na internet.

O aluno Wi. do terceiro ano, apresentou forte influência de interesses prévios e motivação do Contexto Pessoal que foi constatado por suas respostas ao questionário inicial e final, discussões durante o curso e na entrevista final. O aluno, por saber muito mais que seus colegas, muitas vezes inibiu-os de responder algumas questões levantadas pela pro- 
fessora. O aluno é um exemplo evidente da importância de se considerar a influência de diferentes contextos na aprendizagem de conceitos em museus de ciências. Não devemos nos ater somente ao ganho cognitivo dos visitantes, mas preocuparmos especialmente com a origem de seus conhecimentos prévios, como processo chave para o ensino em espaços não formais.

A resposta de We. do terceiro ano de que esperava observar todo o espectro eletromagnético, provavelmente advém de conhecimentos teóricos de livros didáticos de física sobre o espectro eletromagnético, sem discutir as implicações práticas em observá-lo, sendo fruto de conhecimentos prévios do Contexto Pessoal.

Os conhecimentos iniciais dos alunos sobre outras radiações emitidas pelo Sol, provavelmente são fonte de informações provenientes do que aprenderam na escola, nas aulas de química e física do ensino médio, uma vez que todos os alunos sabiam que o Sol emite radiações além do visível. Portanto, são provavelmente resultado de conhecimentos prévios do Contexto Pessoal. Ao mesmo tempo resultam de experiências prévias deste mesmo contexto, pois todos sentem o calor proveniente do Sol e sabem dos efeitos nocivos que os raios ultravioleta podem causar para uma pessoa.

As respostas dos alunos ao questionário final e entrevistas finais, foram influenciadas pelo Contexto Físico e o Contexto Sócio-Cultural. O Contexto Físico exerceu um papel importante, uma vez que o espaço físico proporcionou a contextualização do que estava sendo ensinado por meio da observação do espectro solar e de lâmpadas o que permitiu aos alunos que as comparassem entre si. A observação atenta e a comparação entre os espectros observados gerou discussões, no Contexto Sócio-Cultural, que auxiliaram os estudantes a compreenderem o que estava sendo observado. Outro papel importante do Contexto Sócio-Cultural foi a discussão e descrição do experimento da descoberta do infravermelho para ilustrar que o espectro solar não está restrito somente à região do visível.

Em relação ao futuro do Sol daqui a 5 bilhões de anos, muitos alunos responderam à questão do questionário inicial (apêndice D) afirmando que o mesmo irá esquentar e explodir. Os alunos L. e T. ambos do segundo ano acrescentaram em suas respostas, que 
o Sol ao explodir irá destruir todo o Sistema Solar. A aluna C. do segundo ano escreveu que o Sol irá se tornar mais quente e emitirá mais raios, já as alunas F. do terceiro ano e Ta. do segundo mencionaram termos como gigante vermelha e anã branca em suas respostas, indicando algum conhecimento sobre a trajetória evolutiva do Sol. O aluno Wi., por sua vez, descreveu o que irá ocorrer com o Sol, decorridos 5 bilhões de anos de acordo com o explicado no curso.

Explicamos a trajetória evolutiva do Sol usando slides do Power Point. Uma discussão que permitiu despertar a curiosidade dos alunos foi interrogá-los sobre o fato de o Sol possuir elementos mais pesados do que o hélio, uma vez que ele não é capaz de sintetizálos. Tal discussão abordou tópicos de evolução estelar, envolvendo os processos e condições necessárias para a síntese de elementos mais pesados do que o hélio. Obviamente, os alunos estavam curiosos de como poderia haver ferro, mercúrio e outras linhas de elementos mais pesados no espectro solar. Eles foram lembrados de que somente observamos os elementos presentes na atmosfera solar e não em seu núcleo. Isto fez com que perguntassem se o Sol havia de alguma maneira incorporado estes elementos de outros locais do Universo. Sabemos que estes elementos se originaram de uma estrela mais massiva que o Sol de onde surgiu todo o Sistema Solar. Esta discussão ajudou os alunos a entenderem que as estrelas são gigantescos reatores nucleares responsáveis pela síntese dos elementos químicos e que quando uma estrela massiva morre seu material é reciclado e reutilizado por outras estrelas, como o Sol, para criar planetas e formas de vida (AROCA; SILVA; DIETRICH, 2008). Isto fica evidente, no trecho da entrevista final com o aluno L. do segundo ano.

Prof: Como que existe ferro no Sol se ele não é capaz de sintetizá-lo?

Aluno L: Teve estrelas com mais massa que o Sol que explodiram formando o Sol.

Na questão do questionário final sobre a composição atual do Sol e sua composição e aspecto daqui a cinco bilhões de anos, muitos alunos responderam que ele é composto por hidrogênio e hélio e que daqui a cinco bilhões de anos será uma anã negra com diâmetro aproximadamente igual ao da Terra. Em relação à composição química da anã negra, muitos responderam que será rica em carbono, mas a aluna I. do segundo ano escreveu 
que a composição futura do Sol será de ferro. A aluna provavelmente confundiu o final da trajetória evolutiva de uma estrela com massa pelo menos dez vezes superior ao do Sol, comentada no curso, com a trajetória evolutiva do Sol, que devido à pouca massa não será capaz de sintetizar elementos pesados como o ferro.

Os alunos que afirmaram no questionário inicial que o Sol irá esquentar e explodir, provavelmente leram ou viram informações equivocadas sobre o futuro do Sol na mídia, ou seja, sofreram influência de conhecimentos prévios do Contexto Pessoal. Já as alunas que mencionaram os termos gigante vermelha e anã branca e o aluno Wi. do terceiro ano que sabia o que iria ocorrer com o Sol no futuro, buscaram saber mais sobre o assunto, graças a interesses e motivações prévias do Contexto Pessoal. As respostas ao questionário final e entrevistas finais foram influenciadas pelo Contexto Físico ao observarem o espectro solar e pelo Contexto Sócio-Cultural, que gerou discussões a respeito da existência de elementos mais pesados que o hélio no Sol e de sua trajetória evolutiva.

\subsubsection{Alguns Comentários}

Os resultados obtidos neste trabalho apontam que os alunos do ensino médio, assim como os do ensino fundamental, possuem noções equivocadas sobre distâncias de objetos que estão além da Terra. Mesmo após a conclusão do curso, alguns alunos não conseguiram fornecer dados quantitativos da distância da Terra ao Sol e o diâmetro solar próximos aos obtidos nos cursos. Isto provavelmente ocorreu porque estas dimensões e distâncias são difíceis de serem imaginadas quando comparadas com as dimensões e distâncias que os alunos estão habituados na Terra. Ainda assim, acreditamos que as duas atividades discutidas na seção 6.4.1 proporcionaram uma noção de quais são os instrumentos usados para medir as distâncias dentro do Sistema Solar, a unidade astronômica e para medidas além do Sistema Solar, o ano luz, bem como a noção de quantas vezes o diâmetro solar é maior do que o da Terra.

Os alunos do ensino médio, em geral, apresentaram pré-concepções bastante diferenciadas. Notamos que houve concepções nas quais os alunos afirmaram que o Sol seria quente e gasoso, ou seja, concepções próximas às aceitas pela comunidade científica. Ao mesmo 
tempo, houve pré-concepções nas quais o Sol seria repleto de vulcões, magma e crateras apresentando assim, concepções ingênuas idênticas as dos alunos do ensino fundamental discutidas no capítulo anterior.

As pré-concepções em relação ao espectro solar também foram bastante diversificadas. Alguns alunos não faziam idéia de sua natureza, ao afirmarem que observariam detalhes da superfície terrestre como manchas solares, outros relacionaram o espectro solar às cores do arcoíris, apresentado um certo conhecimento sobre o assunto, houve casos também, do aluno acreditar que iria observar todo o espectro eletromagnético durante o curso por fim, alguns alunos já sabiam que a observação do espectro solar implicaria na observação da composição química do Sol.

Os cursos realizados demonstraram os dois principais métodos de observação solar enfatizando que os mesmos exigem extremo cuidado e que não devem ser realizados sem a supervisão de um especialista. O estudo e a observação de manchas solares e proeminências proporcionaram a noção de que o Sol é um astro dinâmico e que pode influenciar a Terra em muitos aspectos. As atividades realizadas, também permitiram contextualizar o ensino de física solar pela observação do espectro solar e de lâmpadas espectrais que gerou discussões sobre as transições eletrônicas, produção de energia solar e evolução estelar.

Ao final do curso, nenhum aluno apresentou a concepção inicial de que o Sol seria composto por lava ou magma ou que as manchas solares seriam buracos na superfície solar. Acreditamos que isto tenha ocorrido graças à metodologia adotada no curso que privilegiou o confronto das diferentes pré-concepções dos alunos, além da observação de imagens de manchas solares e da observação das proeminências. Além disso, nenhum aluno apresentou a concepção inicial de que a radiação solar é um elemento químico, ou mesmo mencionou o termo "raios solares". Isto provavelmente ocorreu porque os alunos observaram o espectro solar e identificaram os principais elementos presentes concluindo que são os mesmos elementos químicos presentes na Terra. Pelas respostas dos alunos ao questionário final constatamos que compreenderam o porquê de o espectro solar apresentar linhas escuras e as linhas do espectro das lâmpadas serem brilhantes, além da origem das linhas espectrais estarem relacionadas às transições eletrônicas de átomos. As atividades 
realizadas também consideraram o fato de os espectros das estrelas não estarem restritos somente à região do visível.

As respostas dos alunos em relação à composição química do Sol, evidencia um sério problema no ensino formal, os alunos aprendem nomes e palavras como hélio, luz, magma, fotossíntese etc, mas não são capazes de dar significado a eles. Assim, espaços não formais desempenham um importante papel na construção de significado, pois podem fornecer subsídios para que os estudantes compreendam e contextualizem vários conceitos ensinados na escola. 


\section{Considerações finais}

Neste trabalho de pesquisa, buscamos investigar e discutir os conhecimentos de estudantes de quinta à oitava série do ensino fundamental e de alunos do ensino médio relativos ao Sol e à física solar em um espaço não formal de educação, o Observatório Astronômico do CDCC/USP. Olhar para os dados obtidos sob o referencial do Modelo Contextual de Aprendizagem de Falk e Dierking (2000) permitiu investigar a aprendizagem dos temas Sol em um centro de ciências considerando as interações de diferentes contextos que influenciaram no processo.

O Modelo Contextual de Aprendizagem considera a interação de três contextos diferentes. O Contexto Pessoal foi um fator determinante nas pré-concepções apresentadas pelos alunos, pois foram influenciados por experiências prévias, como, por exemplo, perceber que o Sol queima a pele, e com isto concluir que o mesmo deve ser observado com extremo cuidado pelo telescópio, ou ainda, pelos conhecimentos prévios, como por exemplo, a informação de que o Sol é a estrela mais próxima da Terra. Além disso, as motivações e interesses prévios do Contexto Pessoal foram os fatores que fizeram com que os alunos participassem dos minicursos.

O Contexto Físico e o Contexto Sócio-Cultural desempenharam um papel importante durante e após a realização das atividades práticas devido à metodologia adotada. O Contexto Físico permitiu a contextualização do ensino sobre o Sol e aspectos de física solar, na medida em que foi possível observar o Sol, manchas solares, proeminências, espectro de lâmpadas e o espectro solar, além da realização de atividades para se estimar o diâmetro solar comparado ao terrestre, distância Terra ao Sol e estimar a temperatura da fotosfera. O Contexto Sócio-Cultural permitiu o ensino de maneira mais prática e questionadora do que simplesmente usando a sala de aula e livros didáticos. Os estudantes se sentiram desafiados e estimulados durante as atividades, que privilegiaram o uso de diálogos, a realização de experimentos e a observação solar de diferentes maneiras. As discussões das principais idéias apresentadas por eles, também foram fonte de estímulo à aprendizagem dos conteúdos, uma vez que provocaram reflexões e novos questionamentos. 
A maior parte dos alunos teve contato com a Astronomia na escola, e ainda assim, não construíram noções adequadas sobre as dimensões do Sistema Solar, de seus componentes e de outras estrelas. Assim, eles têm o conhecimento de que o Sol é a estrela mais próxima da Terra, porém não possuem uma idéia quantitativa e comparativa das dimensões envolvidas. A mesma observação aplica-se ao tamanho do Sol; em geral, sabem que é maior do que a Terra, mas não de maneira quantitativa. Os resultados obtidos apontam que os estudantes do ensino fundamental tendem a lembrar de características sensoriais dos astros, como cor e forma, mas não se atêm a valores quantitativos como tamanho e distância. Os alunos do ensino médio, também apresentaram dificuldades em compreender as distâncias e dimensões dentro do Sistema Solar, apesar de já possuírem alguma noção quantitativa. As atividades desenvolvidas durante os minicursos permitiram lidar com estas questões, uma vez que foram direcionadas a estimar o tamanho do Sol e sua distância até a Terra, a partir de parâmetros conhecidos, respeitando, obviamente, os níveis de desenvolvimento cognitivo dos alunos. Apesar de algumas dificuldades iniciais, ao final dos minicursos, os alunos apresentaram concepções mais próximas às aceitas pela comunidade científica.

A seguir, retomamos as questões de pesquisa colocadas inicialmente na introdução desta tese. A primeira pergunta foi entender como os alunos do ensino fundamental e médio concebem o Sol.

Os resultados obtidos neste trabalho apontam que os alunos do ensino fundamental concebem o Sol como sendo constituído por fogo; as manchas solares como sendo cavidades; e proeminências solares como labaredas de fogo ou magma. Os estudantes de sétima e oitava séries desenvolveram um modelo em conjunto para explicar a ausência e surgimento de manchas solares relacionadas às proeminências usando conceitos gerais sobre a Terra. Estas concepções ingênuas mudaram após a observação do Sol pelos telescópios do Observatório, questionamento de suas concepções iniciais e devido à intermediação da professora. Os alunos notaram que as manchas solares não poderiam ser buracos causados pelo calor solar, uma vez que aumentavam, diminuíam e se deslocavam a cada nova observação. Outra constatação foi que as proeminências solares, também não poderiam ser de magma. Durante as atividades os alunos acompanharam o surgimento e mudança nas 
características das proeminências e manchas solares. Desta forma passaram a enxergar o Sol como um astro dinâmico, interessante de ser observado e estudado e que afeta nossa vida em muitos aspectos.

Já os alunos do ensino médio apresentaram concepções sobre a natureza do Sol tanto ingênuas quanto científicas. Alguns alunos acreditavam que o Sol é constituído por fogo e lava, enquanto que outros sabiam que o mesmo é composto por hidrogênio e hélio e produz energia por fusão nuclear. Houve também pré-concepções intermediárias entre um realismo ingênuo e o científico como, por exemplo, o de que o Sol produz energia por fusão e fissão nuclear. As concepções de manchas solares e proeminências, também oscilaram entre estes dois extremos, com alunos apresentando as mesmas concepções dos alunos do ensino fundamental e outros que sabiam que as manchas solares são regiões mais frias que a fotosfera e que as proeminências são compostas por hidrogênio ionizado.

Nesta pesquisa buscamo entender como implementar atividades interdisciplinares para o ensino de física moderna em um espaço não formal. Tópicos como a composição química, temperatura e evolução estelares foram ensinados a partir de experimentos clássicos na sala solar com equipamentos de baixo custo. Houve grande ênfase no uso de atividades práticas, observacionais e questionadoras, como estimar a temperatura da fotosfera, observação do espectro solar na região do visível e identificação das linhas de absorção entendendo como são produzidas e que tipo de informações podem ser extraídas a partir delas. Os objetivos de tais atividades foram compreender o papel chave desempenhado pela espectroscopia na astrofísica, contextualizar o conteúdo ensinado com atividades práticas e permitir abordagens interdisciplinares incluindo física moderna e química no ensino de astronomia.

As atividades desenvolvidas com os alunos do ensino médio permitiram discutir um importante tópico de física moderna, o conceito de corpo negro, e ainda abordar conceitos de geometria, calorimetria e evolução estelar. A atividade de observação do espectro solar permitiu discutir tópicos de física moderna como a natureza de linhas espectrais, abordando assuntos como transições eletrônicas no átomo e evolução estelar, como a determinação da composição química de estrelas. Temas de física moderna, como corpo 
negro e transições eletrônicas no átomo são raramente abordados em sala de aula do ensino médio, e quando o são, tornam-se temas abstratos para os alunos, já que dificilmente terão oportunidade de visualizarem linhas espectrais na escola ou aplicarem conceitos de corpo negro de maneira prática. Tais temas deveriam ser desenvolvidos com os alunos por se tratarem de conceitos chaves da física moderna.

A atividade mais interessante para os alunos do ensino médio foi a observação do espectro solar, como afirmaram no final do curso. Mas, antes da atividade, a maior parte deles não sabia exatamente o que é um espectro, embora muitos o relacionaram com o arco-íris. Alguns alunos afirmaram que esperavam observar manchas solares no espectro, demonstrando um total desconhecimento sobre sua natureza. Outros alunos do ensino médio sabiam que a composição do Sol é determinada analisando seus gases ou sua luz. Mas, poucos alunos conheciam como isto é feito, e nenhum deles havia visto um espectro de emissão ou de absorção. O curso permitiu que não apenas observassem o espectro solar, mas que também o comparassem com o produzido por lâmpadas de emissão. Isto gerou discussões sobre as diferenças observadas entre os espectros das lâmpadas e do Sol, que permitiu compreender a natureza do Sol e as transições eletrônicas envolvidas na formação de linhas espectrais. Tal conhecimento, não ficou apenas restrito ao livro didático, na medida em que foi possível contextualizá-lo em um espaço não formal por meio do ensino de espectroscopia solar.

Houve discussões também a respeito da existência de outras radiações emitidas pelo Sol, além do visível, a fim de mostrar que o visível é somente uma parte muito pequena do espectro eletromagnético e que estudando a radiação solar em outros comprimentos de onda obtemos informações relevantes sobre o Sol que não são obtidas na região do visível. Os alunos do ensino médio sabiam que o Sol emite radiações além do visível, infravermelho e ultravioleta. Mas, desconheciam a importância de estudarmos estas outras radiações tanto no Sol quanto em outras estrelas.

Sendo assim, a implementação de atividades interdisciplinares deve considerar uma variedade de tópicos relacionados entre si visando a exploração de conteúdos específicos. As atividades, embora sejam parte de um contexto mais amplo, fazem sentido individu- 
almente e podem ser utilizadas de forma isolada. Apesar disso, quando trabalhadas em conjunto, permitem uma abordagem contextualizada e interdisciplinar.

Desenvolvemos um conjunto de atividades e estratégias metodológicas que permitiu a construção de uma visão mais adequada sobre o Sol e física solar em um espaço não formal de educação. Optamos por desenvolver um conjunto de atividades que permitiu uma visão mais adequada sobre o Sol e física solar no Observatório por meio de mini-cursos, já que os mesmos proporcionam mais tempo de contato entre professora e alunos, com isto havendo a possibilidade de discutir melhor as pré-concepções a respeito do Sol e aspectos física solar, além de realizar observações sistemáticas do Sol. As estratégias metodológicas adotadas foram focadas nas pré-concepções registradas no questionário inicial de maneira que o conhecimento discutido tivesse relação com o universo dos alunos. Com isto, o conteúdo apresentado deixou de ser abstrato e passou a ter um significado para eles como, por exemplo, na discussão de como se determinar a composição química de estrelas e identificar gases em lâmpadas, não exibimos apenas imagens de espectros, mas sim o espectro real, explicando como o mesmo foi obtido e seu significado a partir do manuseio de prismas e redes de difração. O levantamento das concepções iniciais permitiu, ainda discernir alguns traços fundamentais do conhecimento dos alunos: o realismo ingênuo, uma mistura do realismo ingênuo com conceitos científicos e em alguns casos apresentaram também, conceitos científicos. Em geral, os alunos do ensino médio possuem idéias mais próximas às aceitas pela comunidade científica em relação aos alunos do ensino fundamental, como era esperado pelo nível de escolaridade e idade.

A opinião dos alunos após terem realizado os minicursos ficou registrada no questionário de opinião (Apêndice E). Alguns alunos do ensino fundamental afirmaram que aprenderam coisas sobre o Sol que nem imaginavam, como, por exemplo, sua temperatura, composição, "comportamento" e fenômenos dessa estrela que nos faz companhia por 12 horas e que "mal sabíamos seus segredos". As atividades apontadas pelos alunos do ensino fundamental que mais os atraíram foram observar as manchas solares, proeminências além de "jogar palhas de aço sobre imãs e desenhar o Sol no chão colocando botões". Assim como os aluno do ensino fundamental, a maior parte dos alunos do ensino médio preferiu 
as atividades práticas de observação solar às discussões teóricas, sendo a espectroscopia solar a atividade mais apreciada. Isto provavelmente ocorreu porque compreenderam a importância da espectroscopia para o estudo dos astros, além de observarem o espectro solar e compará-lo com o de lâmpadas espectrais. Alguns alunos escreveram também, que aprenderam que o Sol tem diferentes temperaturas, que passar por constantes explosões nucleares e que emite em muitas freqüências de radiações. Muitos alunos do ensino médio e do ensino fundamental comentaram que o curso teve muitas informações novas e interessantes, mas que ainda assim gostariam que tivesse durado mais tempo e que o Sol tivesse mais manchas solares e proeminências. Mesmo o aluno Wi. do terceiro ano, que é um fanático por Astronomia, e conhecia as técnicas de observação solar, comentou que gostou muito do curso Física Solar pois observou, pela primeira vez, o Sol por telescópios, além do espectro de lâmpadas de gases e o espectro solar.

O entusiasmo dos alunos foi generalizado do começo ao fim dos minicursos. Isto se deve, em parte, ao fato de o Observatório Astronômico do CDCC ser um espaço não formal, atrativo, curioso e motivador. Um espaço de ensino não formal como este, permite que os alunos vivenciem a ciência, no caso, a Astronomia, de maneira diferente do que ocorre nas salas de aulas tradicionais. Travando contato com instrumentos astronômicos e observações dos astros, particularmente do Sol, indo muito além das informações dos livros didáticos. A abordagem adotada integrando diálogos, experimentos e observações, teve o objetivo de apresentar aos alunos algumas formas de produção do conhecimento científico (formulações de hipóteses, observações, registros e discussões). A estratégia buscou o máximo de participação dos alunos permitindo tomadas de decisão, questionamentos, reflexões e debates. Além disso, a Astronomia em si é um assunto que desperta grande interesse e permite que os alunos elaborem vários questionamentos acerca da natureza e da posição do homem no universo.

Os cursos oferecidos ao longo deste trabalho atraíram os alunos por motivações intrínsecas, na medida em que foram cursá-los por interesses próprios; assim a aprendizagem ocorreu mais facilmente do que se os cursos fossem impostos pela escola. Os mesmos enfatizaram a observação do Sol e de seu espectro por meio de atividades que exigiram equi- 
pamentos próprios e conhecimentos específicos de como observar o Sol por um telescópio. Portanto, são atividades impossíveis de realizar dentro da sala de aula. Tais atividades permitiram contextualizar os conhecimentos sobre o Sol e seu espectro tornado-os parte da realidade dos alunos e não apenas conceitos abstratos presentes em livros didáticos.

Constatamos após a realização dos cursos, que alguns alunos retornaram ao Observatório para participarem de outras atividades. Para estes alunos, o curso de observação solar foi positivo ao atraí-los para outros temas de Astronomia e outros ramos da ciência. Os contextos fora da sala de aula estimularam os estudantes a promoverem novas conexões com a ciência, pensando mais sobre o tema e suas implicações para a sociedade, além de despertar nos mesmos a consciência de que aprender ciências ultrapassa as barreiras da sala de aula.

Trabalhar conteúdos astronômicos de forma interdisciplinar e ao mesmo tempo de maneira ativa e questionadora traz alguns desafios para as equipes de instituições como o Observatório. Dentre eles, destacamos a necessidade de ter, pelo menos, dois tipos de atividades em um centro de ciências. O primeiro tipo seria atividades que abordam superficialmente os temas, tais como exposições, palestras curtas e observações breves. Estas atividades têm como principal objetivo, o de despertar o interesse do visitante pela ciência. O segundo tipo seria a oferta de minicursos para voluntários, pois a linguagem, conteúdos e metodologias em atividades mais longas podem facilitar abordagens interdisciplinares e integradoras da Astronomia com outras áreas do conhecimento científico pouco exploradas nas salas de aula.

Assim, é vital que o professor conheça com mais profundidade a Astronomia e outras disciplinas, entre elas a Física e a Química, para que tenha competência em propor atividades integradas e interdisciplinares como as discutidas. Isso pode ocorrer quando o projeto pedagógico da escola é construído coletivamente, envolvendo museus de ciências, professores, escola e alunos. Somente desta maneira será possível conciliar as propostas de um ensino de ciências que considere o contexto fora da escola e que ao mesmo tempo tenha estreita relação com o que o aluno está estudando em sala de aula.

Finalmente, esperamos que esta pesquisa tenha contribuído não apenas para os alunos 
que participaram dos minicursos, mas especialmente para professores e educadores de museus, além da comunidade acadêmica a repensarem o ensino de Astronomia, considerando a contextualização do tema em espaços não formais, como sendo o processo chave para a motivação e a aprendizagem de ciências. 


\section{Referências}

AGAN, L. Stellar ideas: Exploring students' understanding of stars. Astronomy Education Review, v. 3, n. 1, p. 77-97, 2004.

AROCA, S.; SILVA, C.; DIETRICH, S. Fun and interdisciplinary daytime astrophysical activities. Physics Education, v. 43, n. 6, p. 613-169, 2008.

BAILEY, J.M. Development of a concept inventory to assess students' understanding and reasoning difficulties about the properties and formation of stars. Astronomy Education Review, v. 6, n. 2, p. 133-139, 2008.

BAMBERGER, Y.; TAL, T. Learning in a personal context: levels of choice in a free choice learning environment in science and natural history museums. Science Education, v. 91, p. 75-95, 2006.

BARRABÍAN, D. Por qué veranos e inviernos? Representaciones de estudieantes y futuros maestros sobre algunos aspectos del modelo Sol-Tierra. Enseñanza de la Ciencia, v. 13, p. 227-236, 1995.

BAXTER, J. Childrens' understanding of familiar astronomical events. International Journal of Science Education, v. 11, special issue, p. 502-513, 1989.

BAXTER, J. H.; PREECE, P.F.W. A comparison of dome and computer planetaria in the teaching of astronomy. Research in Science and Technological Education, v. 18, n. 1, p. 63-68, 2000.

BENCZE, L.; HODSON, D. Changing practice by changing practice: toward more authentic science and science curriculum development. Journal of Research in Science Teaching, v. 36, n. 5, p. 521-539, 1999.

BHATNAGER, A.; LIVINGSTON, W. Fundamentals of solar astronomy. Singapura: World Scientific Publishing Co. Pte. Ltd., 2005.

BISCH, S.M. Astronomia no ensino fundamental: natureza e conteúdo do conhecimento de estudantes e professores. 1998. 301 p. Tese (Doutorado) - Faculdade de Educação, Universidade de São Paulo, São Paulo, 1998.

BRASIL. Secretaria de educação média e tecnológica. Parâmetros Curriculares Nacionais: terceiro e quarto ciclos do ensino fundamental - ciências naturais, 1998. Brasília. MEC/SEMTEC.

BRAUND, M.; REISS, M. Towards a more authentic science curriculum: the contributions of out-of-school learning. International Journal of Science Education, v. 28, n. 12, p. 1373-1388, 2006.

BRISSDEN, G.; BRUNING, D.H.; SLATER, T.F. SABER: A Searchable Annotated Bibliography of Education Research in Astronomy. 2002, Washington. v. 34, Bulletin of the American Astronomical Society, 2002, p. 660.

BULGARELli, D.; HAUN, L. Brincando e aprendendo astronomia, 2007. Disponível em: <http://www.cientec.or.cr/pop/2007/BR-DomingosBulgarelli.pdf>. Acesso em: 4 dez. 2008. 
BURTNYK, K. Impact of observatory visitor centers on the public's understanding of astronomy. Publications of the Astronomical Society of Australia, v. 17, p. 275-281, 2000.

CANIATO, R. O céu. São Paulo: Editora Ática, 1990.

CAZELLI, S.; FRANCO, C. Alfabetismo científico: novos desafios no contexto da globalização. Ensaio - Pesquisa Educação Ciência, v. 3, n. 1, p. 1-18, 2001.

CAZELLI, S.; MARANDINO, M. Educação e comunicação em museus de ciência: aspectos históricos, pesquisa e prática. In: GOUVÊA, G.; MARANDINO, M.; LEAL, M.C. Educação e Museu: a construção social do caráter educativo dos museus de ciências. Rio de Janeiro: Editora Acess, 2003. p. 83-106.

CHESTER, T. Reconciling the Herschel experiment, 1999. Disponível em: $<$ http://la.znet.com/ schester/calculations/herschel/index.html>. Acesso em: 22 jun. 2008.

COLOMBO JÚNIOR, P.; SILVA, C. Alfabetização científica em centros de ciências: o caso do CDA-USP. In: X ENCONTRO DE PESQUISA EM ENSINO DE FÍSICA (EPEF). 2007, Londrina. Atas do X Encontro de Pesquisa em Ensino de Física, São Paulo: Sociedade Brasileira de Física, 2007, p. 1-8.

COMTE, A. Cours de Philosophie Positive. Paris: J.-B. Baillière, 1835.

COSTA, J.R. Astronomia e futebol, 2006. Disponível em: <www.zenite.nu>. Acesso em: 08 dez. 2008.

COSTA, T.; CALBO, S.; OLIVEIRA, E. Estudo das Manchas Solares, 1995. Disponível em: <http://www.cdcc.sc.usp.br/cda/producao/sbpc94/index.html>. Acesso: 15 fev. 2008.

DIAKIDOY, I.A.; VOSNIADOU, S.; HAWKS, J.D. Conceptual change in astronomy: Models of the Earth and of the day-night cycle in American-Indian children. European Journal of Psychology Education, v. 12, n. 2, p. 159-184, 1997.

DOVE, J. Does the man in the moon ever sleep? An analysis of student answers about simple astronomical events: a case study. International Journal of Science Education, v. 24, n. 8, p. 823-834, 2002.

FALCÃO, D.; COLINVAUX, D.; KRAPAS. A model-based approach to science exhibition evaluation: a case study in a Brazilian astronomy museum. Internationa Journal of Science Education, v. 26, n. 8, p. 951-978, 2004.

FALK, J. Free-choice science education:how we learn science outside of school. In: FreeChoice Science Learning: Framing the discussion. Nova Iorque: Teachers College Press, 2001. p. 3-19.

FALK, J.; DIERKING, L. The museum experience. Washington: Whalesback Books, 1992.

FALK, J.; DIERKING, L. Learning from museums: visitor experience and making a meaning. Laham: AltaMira, 2000. 
FALK, J.; STORKSDIECK, M. Learning science from museums. História, Ciências, Saúde - Manguinhos Rio de Janeiro, v. 12, n. 1, p. 1-15, 2005.

FERRIS, T. O despertar na Via Láctea. Rio de Janeiro: Editora Campus, 1990.

FIELDS, D.A. What do students gain from a week at science camp? Youth perceptions and the design of an immersive, research-oriented astronomy camp. International Journal of Science Education, p. 1-21, 2008. DOI 10.1080/09500690701648291.

FLETCHER, J.K. Traditional planetarium programming versus participatory planetarium programming. School Science and Mathematics, v. 80, n. 3, p. 227-232, 1980.

FRANCO, C. As idéias dos alunos sobre temas científicos: vale a pena levá-las a sério? Ciência \& Ensino, n. 4, p. 10-17, 1998.

GALILEI, GALILEO. Istoria e Dimostrazioni Intorno Alle Macchie Solari E Loro Accidenti. Roma: Theoria, 1613.

GASPAR, A. Museus e centros de ciências: conceituação e proposta de um referencial teórico. 1993. 173 p. Tese (Doutorado) - Faculdade de Educação, Universidade de São Paulo, São Paulo, 1993.

GONZALES, E.; NADER, R.; MELLO, A. A astronomia como ferramenta motivadora no ensino de ciências, 2004. Disponível em: <http://www.ufmg.br/congrext/Educa/Educa5.pdf>. Acesso em: 22 jul. 2008.

GRIFFIN, J. Moving from task-oriented to learning-oriented strategies on school excursions to museums. Science Education, v. 81, n. 6, p. 763-779, 1997.

GRIFFIN, J. Research on students and Museums: looking more closely at students in school groups. Science Education, v. 88 (Supp. 1), p. S59-S70, 2004.

HART, C. Framing curriculum discursively: theoretical perspectives on the experience of VCE Physics. International. Internationa Journal of Science Education, v. 24, n. 10, p. 1055-1077, 2002.

HÖNEL, J. Setor de Astronomia do CDCC, 1996. Disponível em: $<$ http://www.cdcc.sc.usp.br/cda >. Acesso: 15 ago. 2008.

JENKINS, E. School science, citzenship and the public understandingo of science. International Journal of Science Education, v. 21, n. 7, p. 703-710, 2001.

JONHSON, L.; WAYMAN, M. The Sun and earth size comparision, 1997. Disponível em: <http://vathena.arc.nasa.gov/curric/space/sun/sunearth.html> . Acesso: 30 out. 2007.

KRASILCHIK, M. Reformas e realidade o caso do ensino de ciências. São Paulo em perspectiva, v. 14, n. 1, p. 85-93, 2000.

LANGHI, R. Um estudo exploratório para inserção da astronomia na formação de professores dos anos iniciais do ensino fundamental. 2004. 243 p. Dissertação (Mestrado) - Faculdade de Ciências, Universidade Estadual Paulista, Bauru, 2004. 
LEITE, C. Os professores de ciências e suas formas de pensar a astronomia. 2002. 160 p. Dissertação (Mestrado) - Instituto de Física e Faculdade de Educação, Universidade de São Paulo, São Paulo, 2002.

LEITE, C. Formação do professor de ciências em astronomia: uma proposta com enfoque na espacialidade. 2006. 256 p. Tese (Doutorado) - Instituto de Física e Faculdade de Educação, Universidade de São Paulo, São Paulo, 2006.

LEITE, C.; HOSOUME, Y. Astronomia nos livros didáticos - um panorama atual, 2005. Disponível em: <http://www.sbf1.sbfisica.org.br/eventos/snef/xvi/cd/resumos/T02251.pdf $>$. Acesso em: 3 ago. 2008.

LEITNER, A. The life and work of Joseph Fraunhofer (1787-1826). American Journal of Physics, v. 43, n. 1, p. 59-68, 1975.

LÓPEZ, A. Una aproximación a las representaciones del alumnado sobre el Universo. Enseñanza de la Ciencia, v. 13, n. 3, p. 371-377, 1995.

LÜDKE, M.; ANDRÉ, M. E. D. A. Pesquisa em educação: abordagens qualitativas. São Paulo: Editora Pedagógica e Universitária LTDA, 1986.

MALI, G.B.; HOWE, A. Development of Earh and gravity concepts among nepali children. Science Education, v. 63, n. 5, p. 685-691, 1979.

MARANDINO, M.; VALENTE, M.E.; CAZELli, S.; AlVES, F.; GOUVÊA, G.; FALCÃO, D. Estudo do processo de transposição museográfica em exposição do MAST. In: Gouvêa G. and Marandino, M. and Leal, M.C. Educação e Museu: a construção social do caráter educativo dos museus de ciências. Rio de Janeiro: Editora acess, 2003. p. 161-187.

MEADOWS, A.J. Early solar physics. Oxford: Pergamon Press, 1966.

MILLS, A. A. Heliostats, Siderostats, and coelostats: A review of practical instruments for astronomical applications. Journal of the British Astronomical Association, v. 95, n. 3, p. 89-99, 1985.

MOREIRA, M. Teorias da aprendizagem. São Paulo: editora pedagógica e universitária, 1999.

MORTIMER, E. Linguagem e formação de conceitos no ensino de ciências. Belo Horizonte: Editora UFMG, 2000.

NICOLINI, J. Manual do astrônomo amador. Campinas: Papirus, 1985.

NUSSBAUM, J.; NOVAK, J.D. An assessment of children's concepts of the Earth utilizing structured interviews. Science Education, v. 60, n. 4, p. 535-550, 1976.

OLIVEIRA, E.; VOELZKE, M.; AMARAL, L. Percepção astronômica de um grupo de alunos do ensino médio da rede estadual de São Paulo da cidade de Suzano. Revista Latino-Americana de Educação em Astronomia, n. 4, p. 79-99, 2007.

PEDROCHI, F.; NEVES, M. Concepções astronômicas de estudantes no ensino superior. Revista Eletrônica de Enseñanza de las ciencias, v. 4, n. 2, 2005. 
PLUMMER, J.D. A Cross-age study of childrens' knowledge of apparent celestial motion. Internationa Journal of Science Education, p. 1-35, 2008. DOI 10.1080/09500690802126635.

REED, G.; CAMPBELL, J.R. A comparison of the effectiveness of the planetarium and the classroom chalkboard and celestial globe in the teaching of specific astronomical concepts. School Science and Mathematics, v. 72, n. 5, p. 368-374, 1972.

RIORDAN, R. Measuring the size of the Sun, 2002. Disponível em: $<$ http://vts.bc.ca/pgrasc/StudentHandouts/solardistance.html>. Acesso em: 11 jul. 2008.

SCARINCE, A.; PACCA, J. Um curso de astronomia e as pré-concepções dos alunos. Revista Brasileira de Ensino de Física, v. 28, n. 1, p. 89-99, 2006.

SCHATZ, D.; LAWSON, A. Effective astronomy teaching: Intellectual development and its implications. Mercury, v. 5, n. 4, p. 6-13, 1976.

SCHIEL, D.; FREITAS, D. Experimentoteca para o ensino médio., 2005. Disponível em: <http://www.cdcc.sc.usp.br/experimentoteca>. Acesso em: 02 ago. 2008.

SHARP, J.G. Children's astronomical beliefs: A preliminary study of year 6 children in south-west England. International Journal of Science Education, v. 18, n. 6, p. 685-712, 1996.

SILVA, A. Nossa estrela: o Sol. São Paulo: Editora Livraria da Física, 2006.

SMITH, M. Non formal education, 2001. Disponível em: <http://www.infed.org/biblio/bnonfor.htm>. Acesso em: 12 nov. 2008.

SUNAL, D. W. Analysis of research on the educational uses of a planetarium. Journal of Research in Science Teaching, v. 13, n. 4, p. 345-349, 1976.

TRAN, L. Teaching science in museums: the pedagogy and goals of museum educators. Science Education, v. 91, n. 2, p. 278-297, 2007.

TRUMPER, R. A cross-age study of junior high school students' conceptions of basic astronomy concepts. International Journal of Science Education, v. 23, n. 11, p. 1111-1123, 2001.

VEIO, F.; HIGGINS, L. The Zeeman effect observed with a spectrohelioscope. Journal of the british astronomical association, v. 166, n. 1, p. 32-33, 2006.

VOSNIADOU, S.; BREWER, W.F. Mental models of the Earth: A study of conceptual change in childhood. Cognitive Psychology, v. 24, n. 4, p. 535-585, 1992.

ZEILIK, M. Astronomy the evolving Universe. Nova Iorque: Jonh Wiley \& Son, Inc., 1997.

ZIRBEL, E. Framework for conceptual change. Astronomy Education Review, v. 3, n. 1, p. 62-76, 2004.

ZIRIN, H. Astrophysics of the Sun. Nova Iorque: Cambridge University Press, 1988. 


\section{APÊNDICE A - Alguns aspectos de física solar ade- quados ao ensino}

\section{O Sol}

Neste apêndice são abordados de maneira breve, alguns aspectos da física solar que foram discutidos nos minicursos. Para uma visão mais detalhada recomendamos as referências: BHATNAGER; LIVINGSTON (2005), SILVA (2006), ZEILIK (1997) e ZIRIN (1988).

Apesar de vermos o Sol todos os dias, e sobrevivermos graças à sua energia, sua natureza é para a maioria das pessoas misteriosa e intrigante. Ao mesmo tempo, é a estrela mais próxima da Terra e, portanto, a mais estudada por cientistas.

O Sol é basicamente uma estrela anã (se comparada à maior parte das estrelas da Via Láctea) com aproximadamente 1,4 milhões de quilômetros de diâmetro. Encontra-se a aproximadamente 150 milhões de quilômetros da Terra, enquanto que a estrela mais próxima da Terra depois do Sol, Próxima Centauri, encontra-se a mais de 40 trilhões de quilômetros do Sol.

Para que o Sol não colapse ou mesmo sofra explosão existe um equilíbrio de forças que o mantém estável. As principais forças que atuam são a gravidade e a pressão de radiação do gás solar. A gravidade irá sempre puxar qualquer elemento de volume para seu centro, enquanto para balancear a gravidade deve-se ter a mesma força no sentido contrário (do centro para as extremidades do Sol). Este equilíbrio de forças no interior solar é denominado de equilíbrio hidrostático (mais informações consultar Bhatnager e Livingston (2005)). Mas ainda, permanece a questão de como a energia solar é produzida.

\section{A.1 Produção de energia solar}

No passado, muitas hipóteses foram propostas para explicar sua natureza pois não se conhecia a fonte de energia do Sol. No século XIX, houve algumas tentativas de explicar a 
energia produzida pelo Sol por combustão de oxigênio e hidrogênio. Sabendo a massa do Sol e a taxa de produção de calor por combustão, o Sol teria somente 3000 anos. Mesmo então, já eram conhecidas pinturas rupestres mais antigas que 3000 anos, portanto foi estranho ter um Sol tão jovem.

Na metade do mesmo século XIX, Hermann von Helmholtz (1821-1894) e Lord Kelvin (1824-1907) propuseram que o Sol brilhava ao liberar energia gravitacional, reduzindo seu diâmetro. A contração gravitacional converteria parte da energia em calor e a outra parte em luz. Segundo os cálculos de Helmholtz e Kelvin, uma contração de 20 m/ano liberaria a energia necessária para o Sol brilhar por aproximadamente 50 milhões de anos. Devido ao desconhecimento do tempo geológico no século XIX, isto parecia um longo tempo de vida para nossa estrela. Mas, no século XX ficou claro por datação de fósseis e registros geológicos, que a Terra existiu por pelo menos algumas centenas de milhões de anos. Foi bastante constrangedor para a comunidade científica ter um Sol mais jovem do que a própria Terra. Para resolver este problema, James Jeans (18771946) propôs na década de vinte do século passado, que a radioatividade seria uma possível solução. Hoje sabemos que esta hipótese é incorreta, mas serviu de guia para os cientistas repensarem a fonte de energia solar como sendo oriunda de transformações de núcleos atômicos (BHATNAGER; LIVINGSTON, 2005).

No final da década de 1930, Hans Bethe (1906-2005) propôs que a fonte de energia solar seria a fusão de prótons em núcleos de carbono, mas hoje se sabe que a principal fonte de energia solar é a fusão de prótons em núcleos de hélio. Bethe calculou a taxa de produção de energia associada ao processo proposto e descobriu que depende fortemente da temperatura, pois com o aumento da temperatura há também um aumento no número de núcleos atômicos colidindo entre si. Estimou também, que a temperatura no núcleo solar seria de 40 milhões de graus C, um valor aceitável, se a produção de energia solar fosse mesmo a partir de carbono. Mas, conforme os estudos avançaram foi calculado que a produção de energia pelo carbono resultaria em uma luminosidade solar bem superior à observada. Cálculos demonstraram que incluindo uma pequena porcentagem de hélio no interior solar diminuiria a temperatura e com isto, a energia produzida pela fusão 
de carbono. A partir de 1950, o modelo teórico de produção de energia solar, passou a considerar aproximadamente $65 \%$ de hidrogênio, $30 \%$ de hélio e $5 \%$ de elementos mais pesados que o hidrogênio e o hélio, resultando numa temperatura de 19 milhões de graus C no núcleo solar. Com o avanço de técnicas de espectroscopia e heliosismologia ${ }^{5}$ hoje sabe-se que a temperatura no núcleo solar é de aproximadamente 15 milhões de graus C e que a fusão por carbono no núcleo solar corresponde à somente $1 \%$ da produção de energia, sendo o restante, resultado da fusão nuclear do hidrogênio em hélio por um processo denominado de cadeia próton-próton (BHATNAGER; LIVINGSTON, 2005).

As reações de fusão nuclear que ocorrem no interior do Sol são bastante complexas, mas podem ser resumidas por quatro núcleos de hidrogênio, transformados em um núcleo de hélio. A massa do núcleo de hélio é $0,7 \%$ vezes menor do que a soma dos quatro prótons (núcleos de hidrogênio) e a massa restante é liberada em forma de energia. Em outras palavras, cada quilograma de hidrogênio perde 7 gramas de massa que é totalmente convertida em energia, de acordo com a equação 8.

$$
\begin{gathered}
E=m c^{2}=\left(4 m_{p}-m_{H e}\right) \times c^{2} \\
=0,007 \times 4 m_{p} \times c^{2}=4,2 \times 10^{-12} J
\end{gathered}
$$

onde, $m_{p}=1,67 \times 10^{-27} \mathrm{~kg}$, é a massa do núcleo de hidrogênio;

$m_{H e}=6,64 \times 10^{-27} \mathrm{~kg}$ é a massa do núcleo de hélio;

$c=3,0 \times 10^{8} \mathrm{~m} / \mathrm{s}$ é a velocidade da luz.

Cada vez que um núcleo de hélio se forma $4,2 \times 10^{-12} J$ de energia é liberado. No núcleo do Sol são consumidas 700 milhões de toneladas de hidrogênio por segundo, criando $10^{38}$ núcleos de hélio. A diferença de massa é de 5 milhões de toneladas $(0,7 \%)$ convertida em energia. Toda esta energia é responsável pela luminosidade do Sol de $3,8 \times 10^{26} \mathrm{~J} / \mathrm{s}$. Esta energia é muito alta, se comparada, por exemplo, com a potência de todas as usinas hidrelétricas, termelétricas e nucleares no Brasil (aproximadamente $9 \times 10^{10} \mathrm{~J} / \mathrm{s}$ ). Seria o

\footnotetext{
${ }^{5}$ Observação de alterações por efeito Doppler produzidas por vibrações de ondas de pressão no interior solar.
} 
equivalente a colocarmos todas as usinas nacionais funcionando durante 150 milhões de anos (SILVA, 2006).

\section{A.2 Estrutura solar}

\section{A.2.1 Do interior para a fotosfera}

Os dados do interior solar são obtidos por modelos de evolução estelar e heliosismologia, uma vez que não é possível observar seu interior. A atmosfera por sua vez, pode ser observada em vários comprimentos de onda, possibilitando assim que tenhamos informações sobre diferentes profundidades das camadas solares.

O interior solar é dividido em três regiões: núcleo, zona de radiação e zona de convecção. A energia produzida no núcleo solar, a uma temperatura de 15 milhões de graus $\mathrm{C}$ é transportada para seu exterior por processos distintos, determinando a existência das camadas solares. Na camada denominada de radiativa que corresponde a 70\% do raio solar, a energia é transportada por radiação. Além desta camada, a absorção se torna excessiva devido ao aumento da densidade de gases e este tipo de transporte deixa de ser eficiente. A partir de então, os processos convectivos passam a entrar em vigor numa camada denominada de convectiva. É interessante mencionar que é entre a camada convectiva e a radiativa que se formam os campos magnéticos do Sol, responsáveis pela atividade solar (SILVA, 2006).

Logo acima do núcleo solar existe a zona radiativa, onde a temperatura oscila entre 2 a 7 milhões de graus C, correspondente à borda do núcleo (25\% do raio solar) até $70 \%$ do raio solar. Nesta região, a radiação é constantemente emitida e reabsorvida fazendo com que os fótons no interior do Sol possam levar de 100 mil a 1 milhão de anos para atingirem sua superfície (figura 29).

Conforme a radiação se aproxima da superfície, a densidade dos gases aumenta muito, tanto que o processo mais eficiente de transporte de energia deixa de ser o radiativo e passa a ser o convectivo. A temperatura também decai de 10000 para cerca de 6000 graus C. 


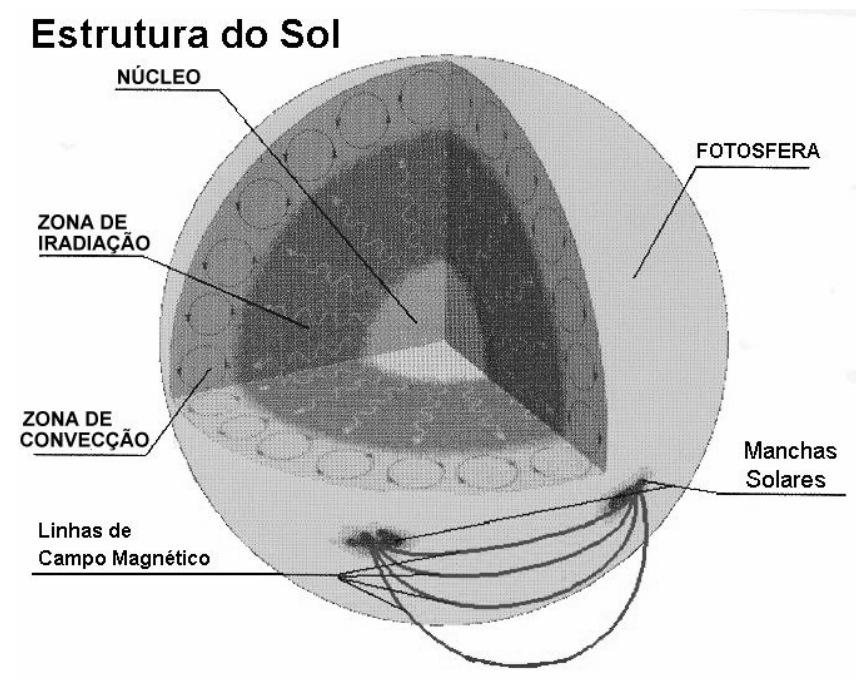

Figura 29 - Estrutura do Sol (COSTA; CALBO; OLIVEIRA, 1995).

O movimento convectivo pode ser visto na superfície do Sol na forma de grânulos, que são formações que possuem aproximadamente $1000 \mathrm{~km}$ de extensão. O movimento de convecção dos gases do interior do Sol é análogo ao movimento de convecção da água dentro de uma panela no fogo, a parte inferior da água, em contato com a panela, diminui de densidade, subindo e depois, resfriando, aumentando sua densidade, descendo novamente para o interior da panela.

\section{A.2.2 Fotosfera solar}

A fotosfera é a camada mais brilhante e significa "esfera de luz", com $300 \mathrm{Km}$ de extensão, e uma temperatura média de 6000 graus $\mathrm{C}$ é onde se encontram as manchas solares e fáculas.

Há muito tempo, as manchas solares têm despertado a atenção de curiosos que observam o Sol. Os chineses, mesmo antes de Cristo, já sabiam da existência das manchas, pois conseguiam vê-las quando o Sol estava nascendo ou se pondo no horizonte, ou até mesmo, quando o astro rei encontrava-se parcialmente coberto por nuvens. Mas, por meio destas observações esporádicas, não foi possível saber se tais manchas estavam na frente do Sol ou em sua superfície, questão que somente foi esclarecida com as observações cuidadosas de Galileu Galilei (1564-1642).

As manchas solares, muitas vezes, atingem o tamanho da Terra e possuem uma tem- 


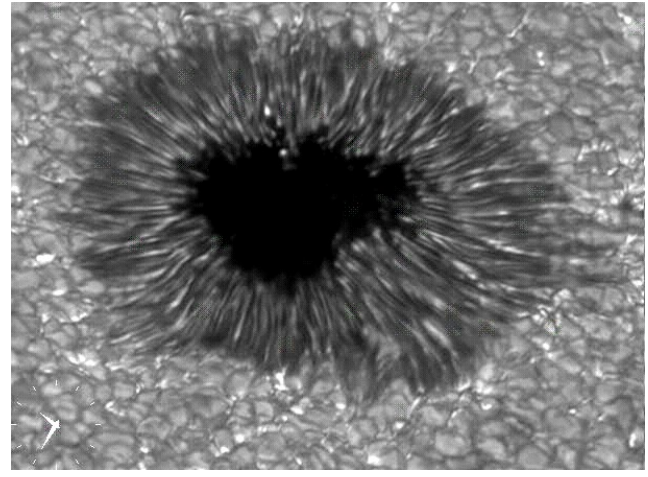

Figura 30 - Imagem mostrando o detalhe de uma mancha solar, umbra e penumbra. Fonte: NASA/GSFC

peratura de 4500 graus C, ligeiramente abaixo da temperatura da superfície solar de 6000 graus C. Por não estarem fixas no Sol, podemos observar o deslocamente das manchas solares após horas de observação. Isto acontece porque o Sol, assim como a Terra, gira em torno de seu eixo. Além de se movimentarem junto com o Sol, as manchas se desenvolvem, ou seja, surgem como pequenos pontos geralmente em regiões mais claras denominadas de fáculas e evoluem no sentido de formar grupos gigantescos atingindo até mesmo, o tamanho do planeta Urano e desaparecem, tornando-se manchas menores e mais escuras. Portanto, as manchas solares são fenômenos interessantes de serem sistematicamente observados e estudados. As manchas solares possuem uma divisão estrutural de umbra (região mais escura) e penumbra (mais clara), conforme pode ser visto na figura 30. Um dos métodos de se observar as manchas solares, o de projeção, está descrito no capítulo 4.

\section{A.2.3 Cromosfera Solar}

Logo acima da fotosfera encontramos a cromosfera que significa, "esfera de cor". Este nome vem do fato de esta camada possuir uma cor próxima do rosa. Sua temperatura é bem superior a da fotosfera atingindo dezenas de milhares de graus e possui $10000 \mathrm{~km}$ de extensão. Esta camada é visível em eclipses solares totais e pode ser observada em comprimentos de onda específicos no visível, ultravioleta e em altas freqüências de rádio (figura 31).

A cromosfera pode ser regularmente observada por meio de filtros especiais denominados de hidrogênio-alfa que permitem a passagem somente da radiação com comprimento 


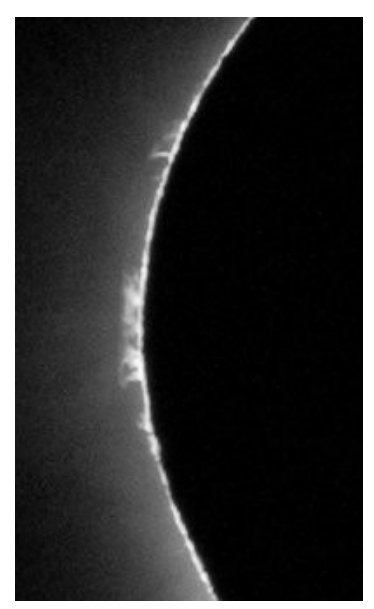

Figura 31 - Cromosfera solar visível durante o eclipse solar total de 2002. Fonte da figura: NASA/Steele Hill/Arne Danielsen

de onda de 656,3 nm, referente a uma das transições do elétron do átomo de hidrogênio. Para que ocorra esta transição, o gás precisa estar a uma temperatura de pelo menos 10000 graus C. Com este filtro é possível observar fenômenos como proeminências, espículas e flares que não são visíveis na fotosfera solar. Estes fenômenos, são muitas vezes, mais interessantes de serem estudados que as próprias manchas solares pois são dinâmicos e mudam suas estruturas em questão de minutos (SILVA, 2006).

As proeminências solares são arcos de hidrogênio ionizados que acompanham as linhas do campo magnético. Estas estruturas, quando não se encontram na borda do Sol, se apresentam como filamentos escuros em contraste ao fundo brilhante. Próximo ao limbo solar também podem ser vistas estruturas que se assemelham a alfinetes que duram de $1 \mathrm{a}$ 20 minutos e sobem alguns milhares de quilômetros, denominadas de espículas (figura 32). Estas estruturas são mais frias e mais densas que o restante do material da cromosfera (SILVA, 2006).

Os "flares" solares são um dos fenômenos mais interessante que existem no Sol. Os "flares" podem ocorrer de repente, liberando imensas quantidadedes de energia equivalentes a bilhões de bombas de hidrogênio de 100 megatons explodindo ao mesmo tempo dentro de um período de 100 a 1000 segundos. Dentro deste curto tempo podem atingir de dezenas a milhares de graus C. Como os "flares" não liberam muita energia na região do visível, eles raramente são vistos na fotosfera. Eles podem, no entanto, ser observados em raios X e ultravioleta na cromosfera. Na figura 33 pode-se ver a imagem de um flare, que 


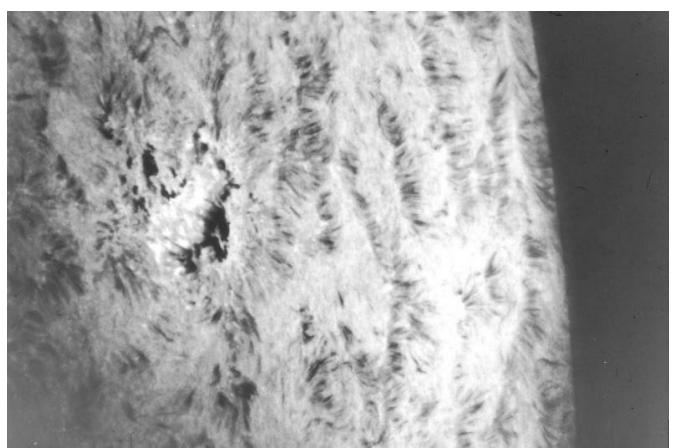

Figura 32 - Imagem da cromosfera mostrando espículas. Fonte: NASA/ Marshall Space Flight Center

neste caso atingiu a altura de aproximadamente $588000 \mathrm{~km}$, o equivalente ao diâmetro de aproximadamente 45 planetas Terra enfileirados (SILVA, 2006).

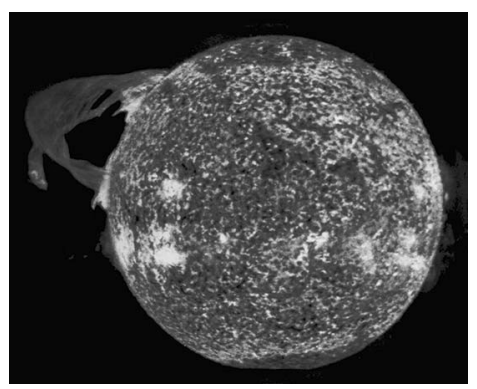

Figura 33 - Imagem de um flare fotografado em ultravioleta extremo em 1973. Fonte: NASA

\section{A.2.4 Coroa solar}

A terceira camada é a coroa, esta é mais extensa que a fotosfera ou a cromosfera, e permeia todo o meio interplanetário. Assim como a cromosfera é visível durante eclipses solares totais, ou pelo uso de um coronógrafo (dispositivo que simula um eclipse solar total) ou por satélites em raios X (figura 34). Sua coloração é branca e atinge temperaturas de milhões de graus C. Esta alta temperatura está associada ao campo magnético que armazena e transporta energia das camadas mais internas do Sol para a coroa.

\section{Vento solar e ejeção de massa coronal}

O vento solar é uma expansão da coroa solar consistindo de elétrons e prótons em um plasma supersônico que atua em todas as direções saindo do Sol a velocidades de 


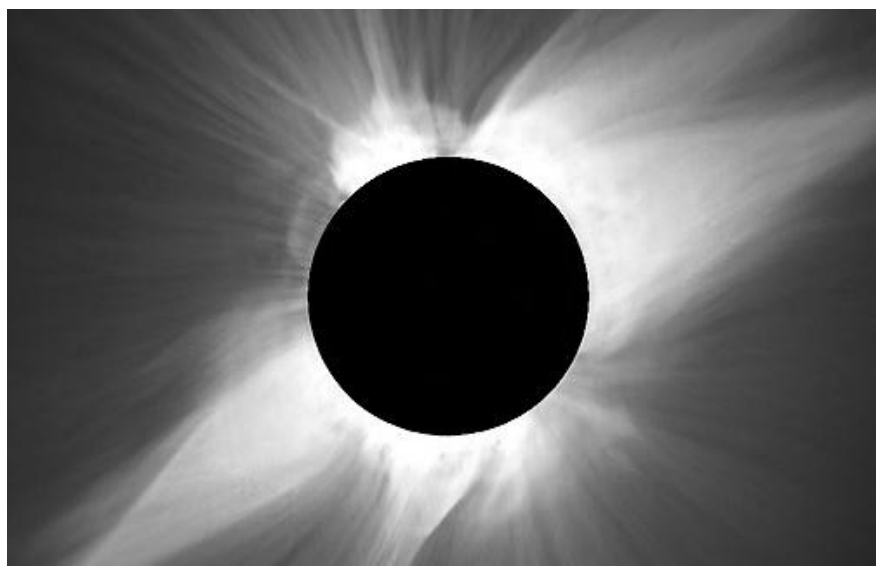

Figura 34 - Coroa solar visível durante o eclipse solar total de 1991. Fonte da figura: High Altitude Observatory at Mauna Kea no Havaí

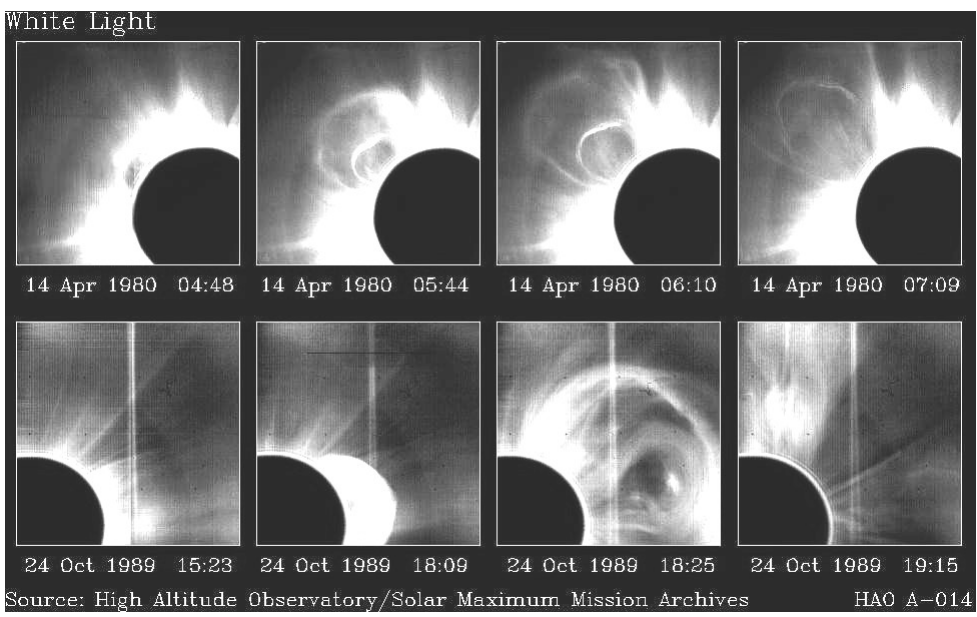

Figura 35 - Imagem mostrando a ejeção de massa coronal. Fonte: High Altitude Observatory

aproximadamente 300 a $1000 \mathrm{~km} / \mathrm{s}$. Uma emissão ainda mais densa e com velocidades superiores ao do vento solar são as ejeções de massa coronal que pode ser visto na figura 35 (BHATNAGER; LIVINGSTON, 2005). Ambos os fenômenos influenciam diretamente as telecomunicações terrestres, como será visto na seção Relações Terra-Sol.

\section{A.3 Espectro solar}

"Entendemos a possibilidade de determinar o formato, distância e movimento dos corpos celestes, no entanto, por nenhum meio seremos capazes de estudar suas composições químicas." Comte (1835) apud Zeilik (1997). Augusto Comte (1798-1857) possuía uma visão pessimista porque não é possível retirar um pedaço de uma estrela e a trazer para a Terra a fim de ser analisada em um laboratório. Tudo que se tem é a luz da estrela que 
penetra os telescópios, entretanto o que ele não sabia é que isto já é o suficiente.

Em Astrofísica existem duas técnicas de observação, a fotometria e a espectroscopia. A fotometria fornece informações sobre o brilho dos astros, o que permite estimar suas distâncias, movimentos e inferir a respeito de alguns processos que provocam as mudanças de brilho observadas. Mas, a fotometria é uma ferramenta restrita, pois não informa a composição química dos astros, uma informação importante quando se pretende, por exemplo, estimar o ciclo evolutivo de uma estrela, determinar sua idade ou constatar a presença de oxigênio. A espectroscopia é a ferramenta mais poderosa que os astrônomos dispõem para estudar o céu, já que é a partir dela que são obtidos um grande número de informações a respeito de um astro distante. A espectroscopia revolucionou a maneira de enxergarmos as estrelas, pois elas deixaram de ser meros pontos luminosos e passaram a ser vistas como objetos celestes como o Sol.

O Sol, assim com as demais estrelas, possui uma assinatura química, como se fosse uma impressão digital. Para se enxergar esta assinatura química, muitas vezes, é necessário dispor de dispositivos que decompõe a luz do Sol, como prismas e redes de difração. No entanto, a natureza nos presenteou com um espetáculo natural que permite ver um espectro criado a partir dos mesmos princípios de funcionamento de um prisma ou rede de difração, o arco-íris. Este é formado pelo fenômeno de refração que distorce o caminho que a luz solar percorre ao passar do ar para as gotículas de água. Cada cor possui uma inclinação própria fazendo com que o arco-íris sempre apresente as cores na mesma ordem. Mas, como que a partir de um prisma que decompõe a luz solar é possível saber a composição química do Sol?

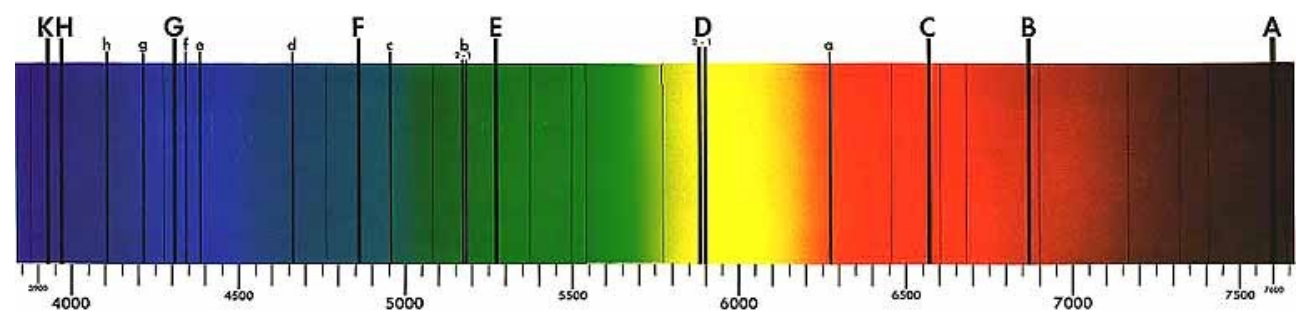

Figura 36 - Espectro solar mostrando as linhas de Fraunhofer. Fonte NASA

Um dos pioneiros em decompor e estudar o espectro solar (figura 36) foi Joseph Fraunhofer (1787-1826). Para isto, ele usou um prisma e um heliostato para acompanhar o 
Tabela 2 - Principais linhas de absorção do espectro solar no visível. As bandas A, B e a pertencem à nossa atmosfera.

\begin{tabular}{|c|c|c|}
\hline Linhas & Elementos & Comprimento de Onda $(\AA)$ \\
\hline \hline banda A & $\mathrm{O} 2$ & $7594-7621$ \\
\hline banda B & $\mathrm{O} 2$ & $6867-6884$ \\
\hline c & $\mathrm{H}$ & 6563 \\
\hline banda a & $\mathrm{O} 2$ & $6276-6287$ \\
\hline D - 1,2 & $\mathrm{Na}$ & $5896 \& 5890$ \\
\hline $\mathrm{E}$ & $\mathrm{Fe}$ & 5270 \\
\hline b - 1,2 & $\mathrm{Mg}$ & 49585173 \\
\hline $\mathrm{c}$ & $\mathrm{Fe}$ & 4861 \\
\hline $\mathrm{F}$ & $\mathrm{H}$ & 4668 \\
\hline $\mathrm{d}$ & $\mathrm{Fe}$ & 4384 \\
\hline $\mathrm{e}$ & $\mathrm{Fe}$ & 4340 \\
\hline $\mathrm{f}$ & $\mathrm{H}$ & 4308 \\
\hline $\mathrm{G}$ & $\mathrm{Fe} \& \mathrm{Ca}$ & 4227 \\
\hline $\mathrm{g}$ & $\mathrm{Ca}$ & 4102 \\
\hline $\mathrm{h}$ & $\mathrm{H}$ & 3968 \\
\hline $\mathrm{H}$ & $\mathrm{Ca}$ & 3934 \\
\hline $\mathrm{K}$ & $\mathrm{Ca}$ & \\
\hline
\end{tabular}

Fonte: http://www.harmsy.freeuk.com/fraunhofer.html.

movimento do Sol (figura 5, maiores informações no capítulo 4) e um fenda com abertura de 40" (LEITNER, 1975). A fenda é a peça chave para verificar que o espectro solar não é formado apenas pelas cores do arco-íris (contínuo), pois há também linhas escuras se sobrepondo ao contínuo. A informação da composição química dos gases e astros é obtida a partir da disposição, intensidade e largura destas linhas. Fraunhofer supôs que as linhas seriam devido à presença de elementos químicos no Sol, uma vez que observou o espectro de outras estrelas e constatou que eram diferentes do Sol. Ao observar o espectro solar ele encontrou 574 linhas escuras, hoje denominadas de linhas de Fraunhofer em sua homenagem (tabela. 2).

O próximo passo é entender o significado das linhas espectrais para determinar quais elementos químicos estão presentes no Sol. Historicamente isto foi feito a partir do estudo do espectro dos elementos presentes na Terra. Ao se observar a luz emitida por uma lâmpada de gás é possível ver algumas linhas brilhantes que variam de cor e posições dependendo do gás. A partir do estudo do espectro de gases é possível registrar a cor, intensidade e posição de cada linha do espectro. Com estas informações, os astrôno- 

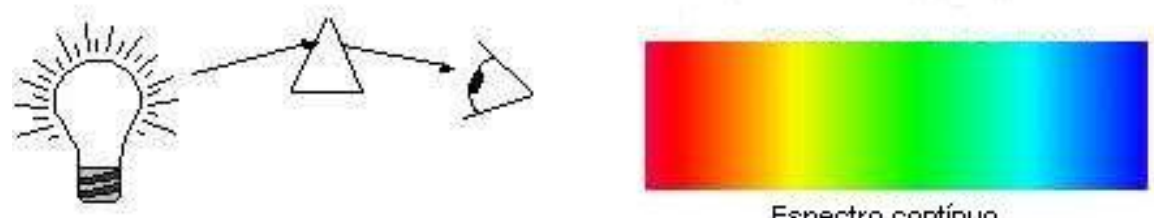

Espectro contínuo
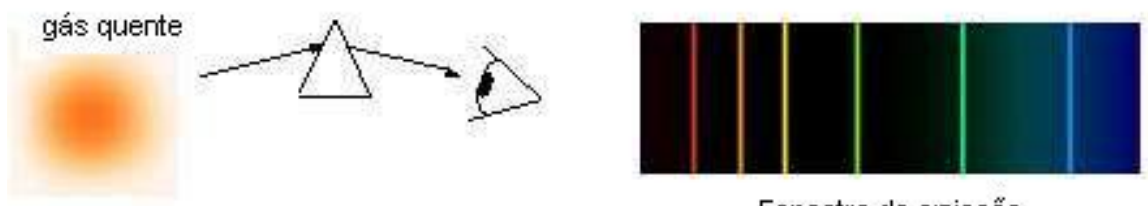

Espectro de emissẵo

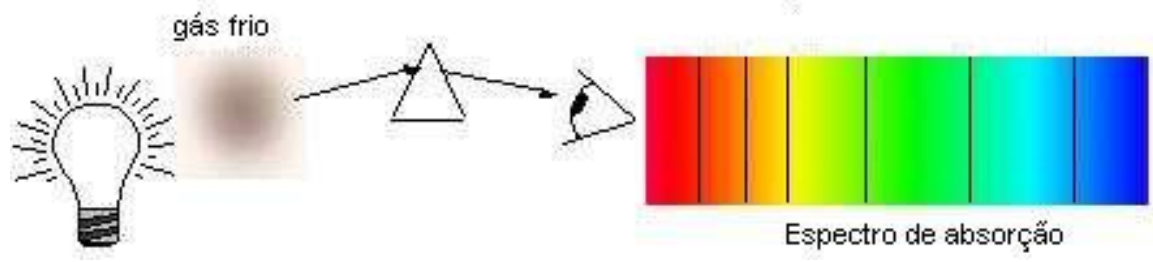

Figura 37 - Ilustração mostrando as leis de Kirchoff. Fonte: NASA

mos estudam o espectro solar comparando a posição e intensidade das linhas com a dos elementos terrestres.

Em outras situações ocorre o contrário, como por exemplo, o hélio foi primeiro descoberto no Sol e depois na Terra, apesar de o espectro solar não apresentar linhas de absorção de hélio. Em 1868, Norman Lockyer (1836-1920) observou uma linha brilhante e amarela numa proeminência solar, não conseguindo determinar à qual elemento correspondia, ele denominou a linha de hélio que significa Sol. Posteriormente, em 1895 William Ramsay (1852-1916) confirmou a existência do hélio na Terra ao isolá-lo de um mineral de Urânio chamado de Cleveite (MEADOWS, 1966).

O motivo pelo qual as linhas espectrais do Sol são escuras, ao contrário das lâmpadas que são brilhantes é que um gás quente e opaco, ou um gás altamente comprimido emite um espectro contínuo, conforme mostrado no espectro superior da figura 37. Um gás quente e transparente produz um espectro de linhas brilhantes ou de emissão, como mostrado no espectro do meio da figura 37. O número de linhas e cores presentes depende de quais elementos estão presentes no gás. Se uma fonte que produz um espectro contínuo passar através de um gás transparente à uma baixa temperatura, o gás frio irá provocar o surgimento de linhas escuras, cujo número e cores dependerá de quais elementos estão presentes no gás, conforme mostrado na figura 37 (ZEILIK, 1997). 
No caso do Sol, as linhas são escuras, pois o núcleo solar emite um espectro contínuo, mas este é absorvido pelo gás mais frio da fotosfera. Como já mencionado, o Sol não emite radiação somente na região do visível, portanto é possível observar o espectro solar em outras faixas espectrais como infravermelho, ultravioleta, raios $\mathrm{X}$, raios gama etc. Cada uma destas faixas fornece informações sobre as diferentes profundidades no Sol.

\section{A.4 Atividade solar}

O Sol é uma estrela dinâmica apresentando além de manchas solares, proeminências, espículas, flares e outros fenômenos muito energéticos. Há dois tipos de magnetismo no Sol, um concentrado na região das manchas solares e outro disperso em todo o astro com uma intensidade inferior ao das manchas.

Galileu Galilei (1564-1642), um dos primeiros observadores do Sol por um telescópio, notou que as manchas solares não estavam estáticas no Sol mas, ao contrário pareciam girar ao redor dele, uma vez que a cada nova observação ele percebia que se deslocavam, conforme pode ser visto na figura 38. Hoje sambemos que o Sol, por ser constituído por gases, não rotaciona de maneira uniforme, ou seja, ele gira mais rápido no equador (cerca de 25 dias) do que nos polos (cerca de 30 dias), este movimento não uniforme é denominado de rotação diferenciada do Sol.

O magnetismo é a chave para entendermos a atividade solar. Numa analogia, os campos magnéticos são como gomas de elástico, pois podem ser esticados, torcidos e dobrados sobre si mesmos. Estes mesmos movimentos são realizados pelo campo magnético no Sol.

George Ellery Hale (1868-1938) percebeu que as manchas solares sempre ocorrem aos pares, o que o inspirou em 1900, a buscar por campos magnéticos em manchas solares pelo efeito Zeeman. Historicamente o magnetismo na região das manchas solares começou a ser desvendado em 1896 com os trabalhos de Pieter Zeeman (1865-1943) envolvendo os efeitos do campo magnético no átomo e com a invenção do espectrohelioscópio no início do século XX por Hale. Este equipamento permitiu medir o campo magnético em manchas solares, uma vez que o alargamento das linhas espectrais observadas é proporcional à intensidade 

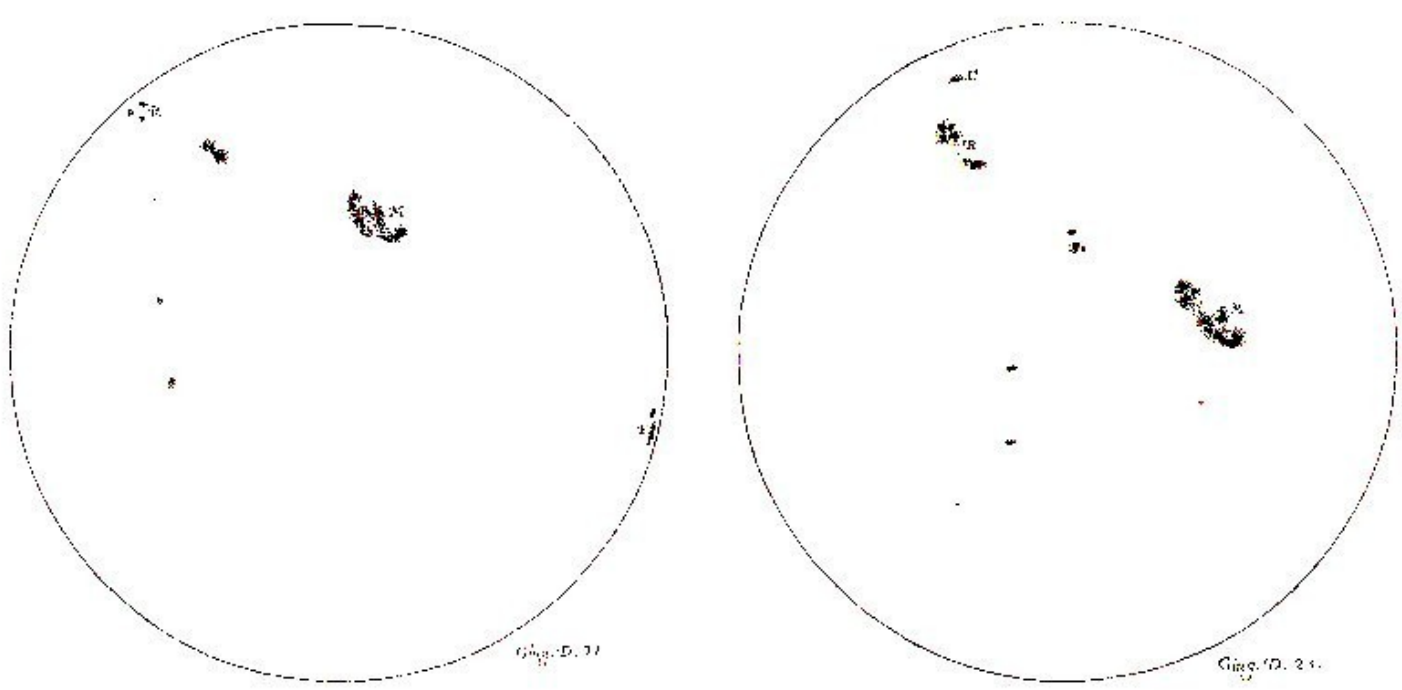

Figura 38 - Desenhos feito por Galileo em 1610 mostrando as manchas solares. Figura da obra: Istoria e Dimostrazioni Intorno Alle Macchie Solari e Loro Accidenti Rome de Galileo Galilei (GALILEI, 1613).

do campo magnético presente nas manchas solares causando um desdobramento dos níveis de energia do átomo. Tal aparelho, é constituído por um interferômetro de Fabry-Perrot. Devido ao fato de o campo magnético nas manchas solares ser bastante intenso, hoje em dia consegue-se confeccionar espectrohelioscópios para medir o efeito Zeeman, sem um interferômetro, uma vez que se pode trabalhar com uma longa distância focal e linhas espectrais de segunda ordem de forma a se obter a dispersão necessária para se observar o fenômeno (VEIO; HIGGINS, 2006).

O campo magnético global do Sol é de 0,01 Tesla sendo equivalente ao campo magnético de um imã de geladeira, mas ainda assim, 100 vezes mais intenso do que o da Terra. Podemos pensar que existe um gigantesco imã no Sol e que as linhas de campo vão do polo norte ao sul do imã (SILVA, 2006). Já o campo magnético nas manchas solares chega a ser milhares de vezes mais intenso que no restante da superfície solar. As manchas não são pretas ou cinzas como vemos ao observá-las por um telescópio. O que acontece é que o fundo brilhante do Sol faz com que as mesmas apareçam escuras quando na verdade são vermelhas.

Embora a formação de manchas solares não esteja totalmente desvendada, hoje sabese que está intimamente relacionada ao campo magnético global do Sol e sua rotação diferenciada, já que a rotação, arrasta lateralmente as linhas de campo magnético. A 

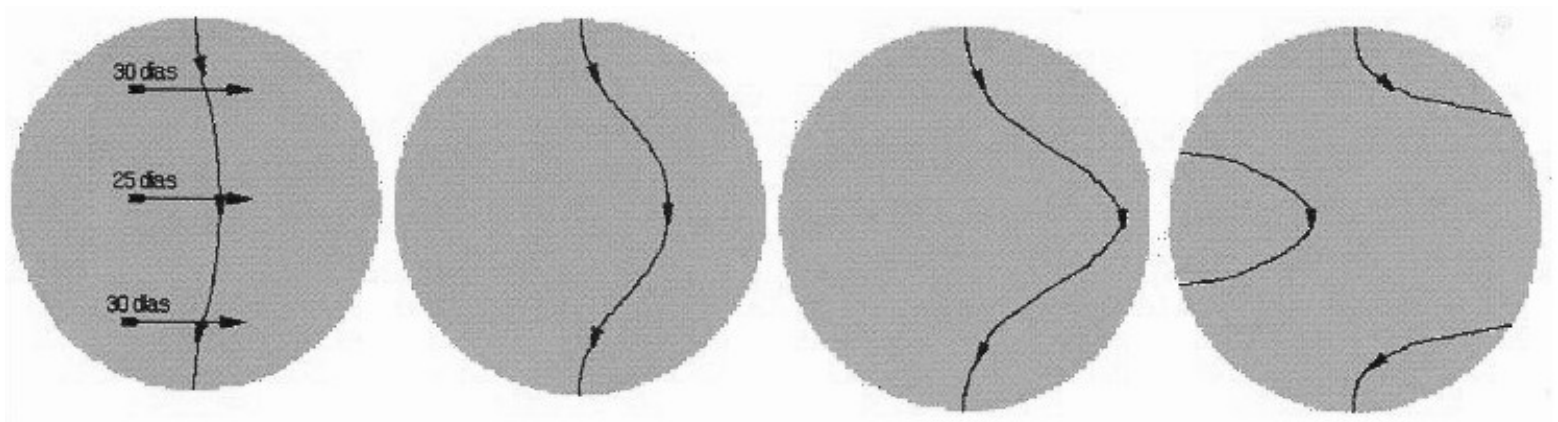

Figura 39 - Distorção das linhas do campo magnético causadas pela rotação diferencial do Sol (COSTA; CALBO; OLIVEIRA, 1995).

cada rotação, as linhas magnéticas aproximam-se mais uma das outras culminando numa repulsão de partículas e no aumento do fluxo magnético (Figura 39). Isso acarreta na expulsão de gases da fotosfera em direção às linhas de campo magnético, fazendo com que estas regiões se resfriem (4300 K). Essa temperatura é bem menor que os usuais $6000 \mathrm{~K}$ da fotosfera nas regiões ausentes de manchas. O campo magnético intenso formado provoca o desvio de correntes de convecção para regiões circunvizinhas que se tornam mais quentes e brilhantes originando as fáculas (COSTA; CALBO; OLIVEIRA, 1995).

\section{A.4.1 Manchas solares e ciclo solar}

Galileu Galilei ficou surpreso ao notar que o Sol não era uma esfera homogênea e perfeita como se acreditava no século XVII. O Sol possuí manchas escuras! Seriam sujeiras na ocular do telescópio? Esta hipótese foi descartada por ele após, observar o Sol assiduamente, notando que as manchas podiam ser vistas dia após dia em posições distintas (figura 38). Outro fato, que o deixou intrigado, é o de que as manchas não estavam estáticas no Sol mas ao contrário, pareciam girar em volta dele. Galileu explicou a existência das manchas solares supondo inicialmente que seriam satélites em volta do Sol, ou mesmo buracos na superfície solar.

A fim de resolver o enigma das manchas solares, Galileu estudou o Sol cuidadosamente e após medir as diferenças nos aspectos das manchas ao aparecerem e desaparecerem no limbo (borda) solar percebeu, que as mesmas diminuam de tamanho próximas ao limbo e aumentavam de tamanho no equador solar. Se estas manchas estivessem acima da 


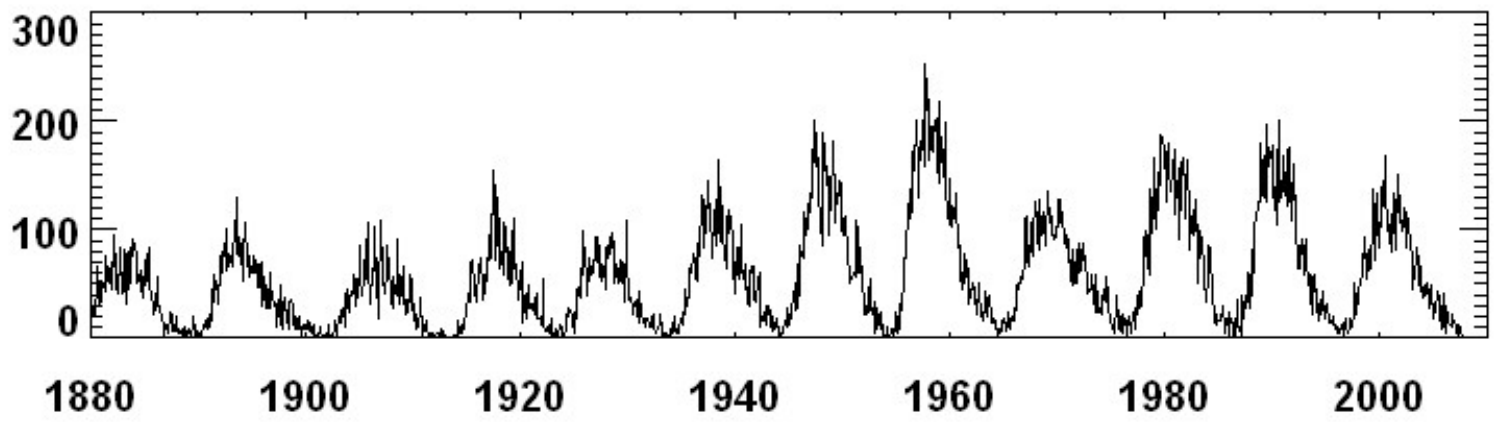

Figura 40 - Gráfico do número de Wolf em função do ano, mostrando vários ciclos solares (subida e descida nas curvas). Fonte: NASA/Marshall Space Flight Center.

superfície solar, ele não veria uma diferença de tamanho quando as mesmas atingissem as regiões do limbo solar, apenas notaria que desapareceriam. Como ele observou esta diferença de tamanho em todas as manchas, ele concluiu, que as mesmas deveriam se encontrar na superfície do Sol e não em volta dele.

No século XIX, Rudolf Wolf (1822-1896) desenvolveu um sistema de contagem de número de manchas solares. Este sistema é muito importante, uma vez que permite traçar os ciclos solares ao se plotar um gráfico com o número de Wolf (W) em função do tempo (figura 40). O primeiro passo é contar o número de grupos de manchas presentes no Sol e multiplicar este valor por 10. Esta multiplicação é feita para assegurar que o número de manchas não foi subestimado, uma vez que pode haver manchas que não foram observadas com o instrumento disponível. Em seguida, conta-se o número total de manchas $(\mathrm{M})$ presentes em cada grupo $(\mathrm{G})$ ou isoladas, soma-se este valor ao número de grupos multiplicado por dez (COSTA; CALBO; OLIVEIRA, 1995).

$$
W=10 G+M
$$

Um exemplo desta contagem pode ser vista na figura 41, onde se nota a presença de três grupos de manchas solares, sendo que dois deles estão no hemisfério norte do Sol e o outro está no hemisfério Sul do Sol. O número total de manchas observado no dia foi de 26 conforme a equação 11.

$$
W=10 \times 3+26=56
$$




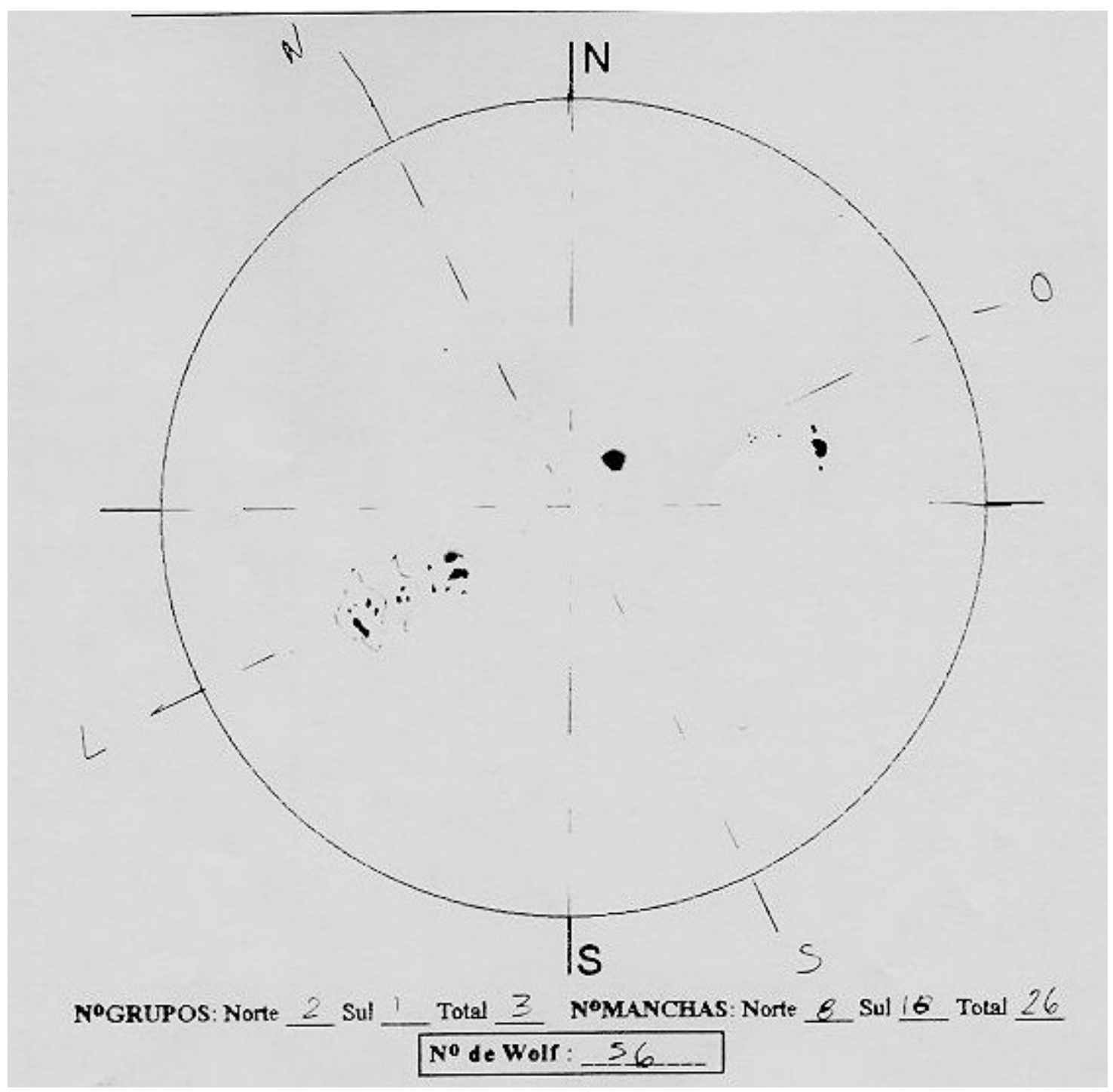

Figura 41 - Observação solar ilustrando a contagem do número de Wolf. Fonte da figura: COSTA; CALBO; OLIVEIRA (1995). 


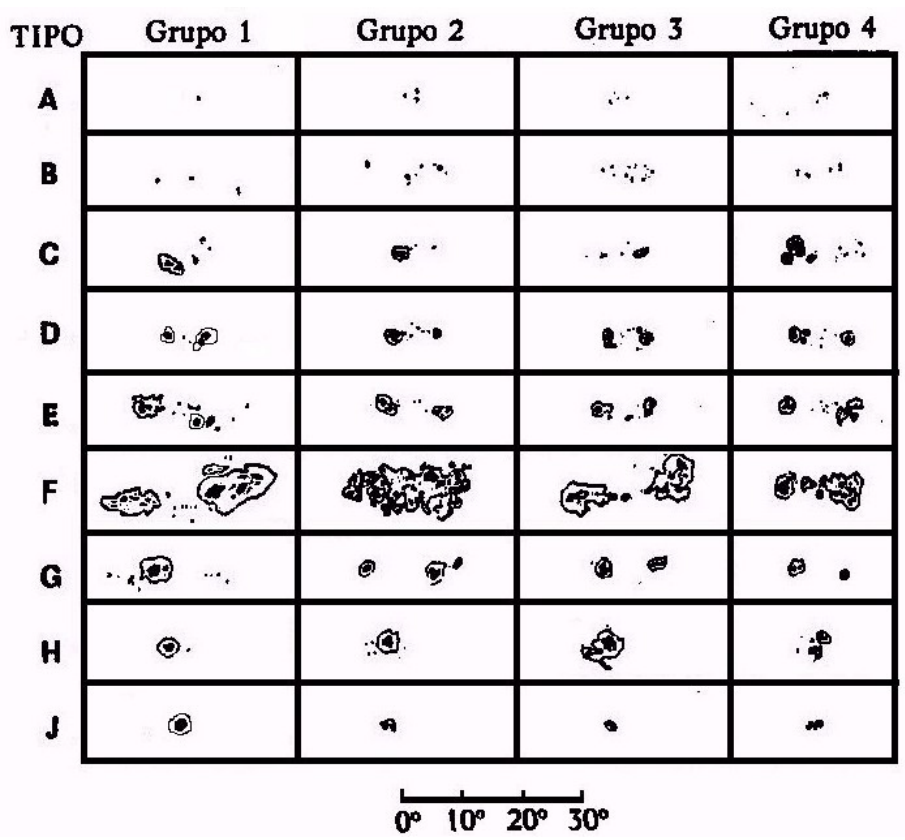

Figura 42 - Classificação de manchas solares (COSTA; CALBO; OLIVEIRA, 1995) .

O movimento de manchas solares notado por Galileu corresponde à rotação solar, mas além de se movimentarem no disco solar, as manchas solares também mudam de formato, conforme já mencionado, com o passar dos dias se desenvolvendo em grupos complexos, que são classificados pelo sistema desenvolvido pelo ex-diretor do observatório de Zurique, Max Waldmeier (1912-2000) conforme pode ser visto na figura 42. Esta classificação obedece ao progresso de evolução do grupo de manchas de acordo com sua origem, sendo dividido em quatro tipos de evolução.

Heinrich Schwabe (1789-1875) percebeu em 1843, que o número de manchas solares mudava, aumentando e diminuindo num período de aproximadamente onze anos, ou seja, o número de manchas crescia durante quatro ou cinco anos atingindo um pico e diminuia nos cinco a seis anos seguintes (figura 40). Mas, o ciclo completo de atividade solar dura o dobro desse intervalo, num processo que regenera continuamente os campos magnéticos. Quando o campo magnético original dos polos desaparece, o campo torcido regenera o campo magnético, mas agora com polaridade oposta. Repetindo este mecanismo, completa-se um ciclo magnético solar de 22 anos (COSTA; CALBO; OLIVEIRA, 1995).

Gustav Spörer (1822-1896) e Richard Christopher Carrington (1826-1875) no século 
XIX notaram que no início de um ciclo solar as manchas se encontram em latitudes mais altas (próximo a 40 graus) e conforme o ciclo progride aparecem em latitudes cada vez mais próximas ao equador. Esta constatação ficou conhecida como lei de Spörer. Isto ocorre devido à tendência de as linhas de campo magnético se torcerem em direção ao equador solar que possui uma rotação maior que nos polos (maiores detalhes ver Modelo de Babcock, p.236 em Bhatnager e Livingston (2005)).

A coroa solar também muda de brilho e formato conforme o período do ciclo solar. Quando o Sol está em época de baixa atividade a coroa se estende mais no equador do que nos polos e em época de alta atividade a coroa, é mais brilhante e uniforme. Estas mudanças são controladas pelas linhas de campo magnético (BHATNAGER; LIVINGSTON, 2005).

\section{A.4.2 Relações Terra-Sol}

Esta seção refere-se às influências que o Sol exerce sobre a Terra, desde causar danos em satélites, afetar astronautas no espaço, confundir sistemas de navegação, interromper comunicação de longa distância, causar danos na fiação elétrica, produzir auroras nos dois hemisférios e afetar o clima terrestre.

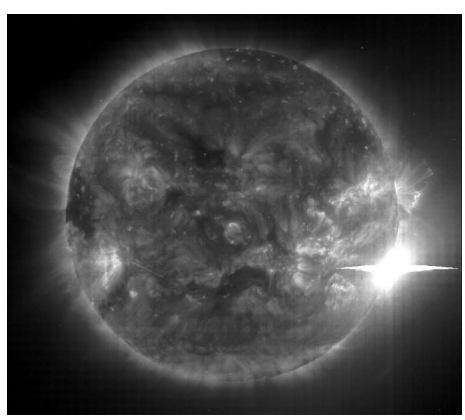

Figura 43 - Imagem do Sol pela sonda Hinode no ultravioleta extremo mostrando um flare. Fonte: NASA/MSFC

Uma das maneiras mais severas que o Sol pode afetar a Terra é pelas tempestades geomagnéticas, que ocorrem com mais freqüência em épocas de alta atividade solar. O vento solar interage com o campo magnético da Terra provocando descargas elétricas em nossa atmosfera que quando intensas originam as tempestades geomagnéticas. Estas duram 
tipicamente algumas horas podendo provocar indução de corrente elétrica em sistemas de fornecimento de energia elétrica provocando variações de freqüência e voltagem. Por exemplo, houve uma tempestade geomagnética no dia 13 de março de 1989 associada a um flare (figura 43) que causou uma falha completa de transmissão de energia elétrica em Quebec no Canadá, destruíndo transformadores e deixando a população sem energia elétrica por muitas horas (BHATNAGER; LIVINGSTON, 2005).

A camada da atmosfera mais afetada pela atividade solar e pelas auroras é a mais externa, a uma altitude de aproximadamente $80 \mathrm{~km}$, denominada de ionosfera. Nesta camada, as partículas são ionizadas devido à ação dos raios ultravioleta do Sol. Esta camada atua como um espelho para as ondas curtas como algumas ondas de rádio transmitidas pelas estações terrestres. Quando o Sol encontra-se em uma época de alta atividade, o número de partículas ionizadas aumenta junto com a temperatura da ionosfera, fazendo com que a mesma mude de densidade e altura. Estas alterações na ionosfera fazem com que as ondas de rádio sejam refletidas para outros locais além das estações de destino (SILVA, 2006).

Os satélites são frequentemente afetados pelas tempestades geomagnéticas que produzem um aumento na densidade de partículas carregadas, provocando um maior atrito na ionosfera, o que pode frear satélites e causar instabilidades em suas órbitas. Isto aconteceu em 1979, com o Sky Lab, um laboratório espacial para se estudar o Sol que acabou caindo prematuramente na Terra devido ao aumento da radiação solar durante uma época de alta atividade (ZEILIK, 1997).

Os astronautas em órbita são ainda mais vulneráveis à ação do vento solar, eles não estão protegidos pela atmosfera terrestre e por isso, estão sujeitos às radiações letais que podem provocar vários tipos de câncer. Os passageiros que cruzam os pólos terrestre de avião, durante uma tempestade geomagnética, em alta altitude também estão sujeitos à ação desta radiação nociva.

A sociedade contemporânea é altamente dependente de GPS ( Global Positioning System ) como sistema de orientação. Durante tempestades geomagnéticas pode haver perda de comunicação com os satélites que fornecem os dados ao GPS, podendo provocar 
perda de orientação de aeronaves e com isto, acidentes aéreos.

As tempestades geomagnéticas menos intensas produzem espetáculos naturais como as auroras. Estas aparecem como luzes coloridas no céu que podem durar algumas horas, sendo provocadas devido à excitação de moléculas e átomos de oxigênio e nitrogênio da atmosfera terrestre por elétrons energéticos oriundos do vento solar. O nitrogênio produz uma luz rósea ou azul e o oxigênio é responsável por luzes verdes e vermelhas. Quando as auroras ocorrem no hemisfério norte são denominadas de boreais e quando ocorrem no hemisfério sul são austrais. Pelo fato de o campo magnético do polo norte ser mais intenso que o do sul, há uma maior incidência de auroras boreais que austrais. As auroras não são exclusivas do planeta Terra, ocorrendo também, em outros planetas com campos magnéticos como, Júpiter e Saturno (BHATNAGER; LIVINGSTON, 2005).

Outra maneira de o Sol afetar a Terra é provocando variações de temperatura. Como por exemplo, entre 1645 e 1715 quando ocorreu a Pequena Era do Gelo. Neste período, a Europa passou por invernos rigorosos chegando a ponto de os canais de Veneza e o Rio Tâmisa de Londres congelarem. Nesta época havia muitos estudiosos observando o Sol e notando que o mesmo não apresentava quase mancha alguma. Hoje em dia sabemos que este não foi o único período de baixíssima atividade solar na história humana. Estudos apontam que houve pelo menos mais duas ocasiões, uma por volta 1300 que ficou conhecido por mínimo de Wolf e outra em 1400-1530, conhecido por mínimo de Spörer (SILVA, 2006).

Como foi descrito acima há vários fenômenos ocorrendo no Sol que são interessantes de serem observados e estudados, alguns até mesmo com impactos consideráveis para a sociedade atual como, por exemplo, os flares. Este tema, embora importante do ponto de vista científico, raramente é ensinado nas escolas brasileiras, seja do ensino fundamental ou do ensino médio, ou mesmo em cursos de formação para professores. 


\section{APÊEDICE B - Heliostato para uso em escolas}

As escolas, muitas vezes, não podem oferecer transporte para os alunos e professores irem até os centros de ciências. Com isto em mente, pensou-se em como trazer a observação solar até a escola. Um protótipo de um heliostato portátil de baixo custo foi desenvolvido contendo uma luneta, dois espelhos planos e um motor de passo que acompanha o movimento do Sol (figura 44). Este dispositivo permite a projeção da imagem do Sol com aproximadamente $5 \mathrm{~cm}$ de diâmetro. Ao observar atentamente o disco do Sol, muitas vezes é possível observar as manchas solares. Com este tipo de atividade, o professor pode demonstrar aos alunos a rotação solar, estudar, contar e classificar manchas solares demonstrando com isto, que o Sol é um astro dinâmico.

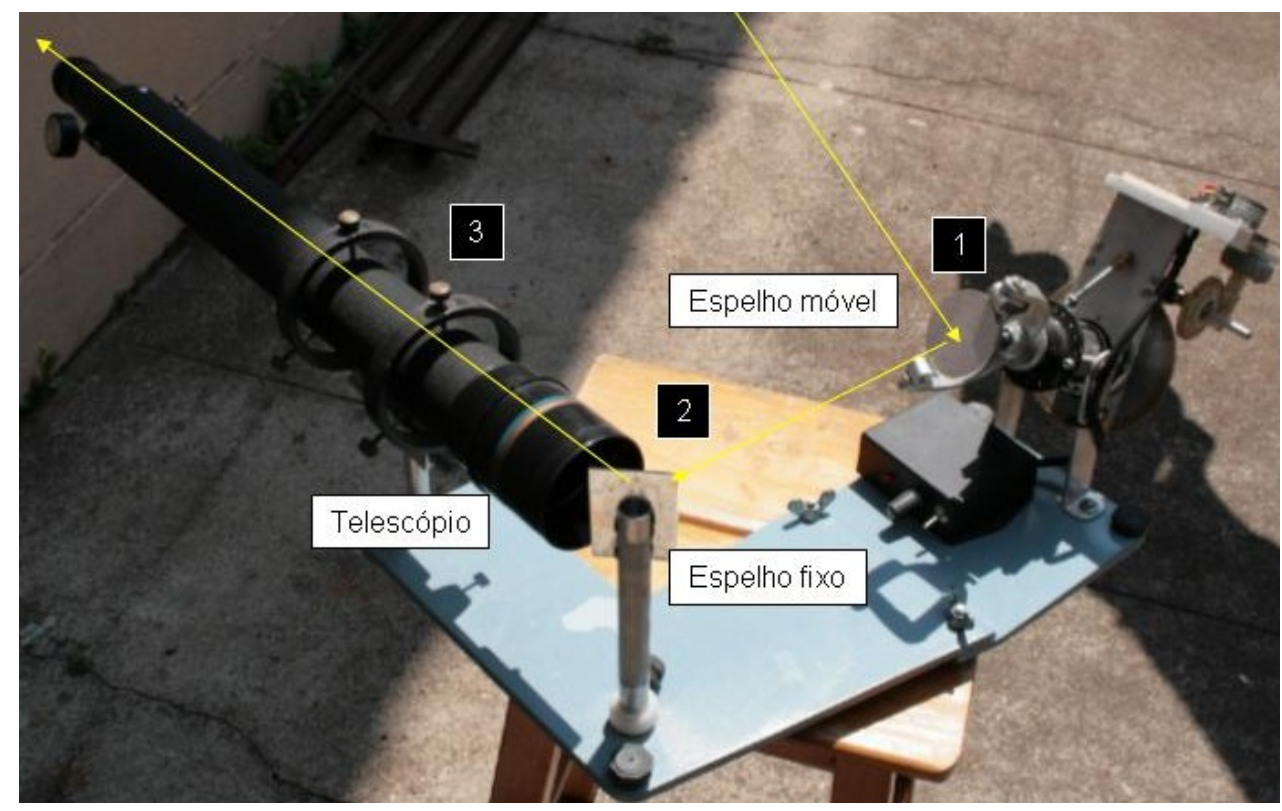

Figura 44 - Heliostato para uso em escolas. A luz solar incide primeiramente no espelho móvel (1), em seguida é direcionada ao espelho fixo (2) que a direciona para o telescópio (3) que projeta a imagem do Sol em sua outra extremidade.

Construção do equipamento:

Utiliza uma luneta com $625 \mathrm{~mm}$ de distância focal e $50 \mathrm{~mm}$ de abertura. Como suporte da base para a luneta e os espelhos foram usadas placas de PVC. O espelho fixo é um espelho plano de 5,5 cm de altura e $4 \mathrm{~cm}$ de largura. O espelho móvel também é plano com $5 \mathrm{~cm}$ de diâmetro e $0,5 \mathrm{~cm}$ de largura com uma planicidade de $\lambda / 4$ (conforme explicado no capítulo 4). Este último espelho foi gentilmente cedido pela oficina de óp- 
tica do Instituto de Física de São Carlos. Os suportes para os espelhos e o telescópio foram confeccionados em alumínio por Dario Pires (o mesmo construtur do heliostato do Observatório) e construídos a partir de peças de bicicleta.

O suporte do espelho móvel faz com que este espelho fique com a inclinação da latitude da cidade de São Carlos, assim como as montagens equatoriais de telescópios que são fixadas de acordo com a latitude do observador, a fim de acompanhar o movimento dos astros na velocidade de rotação da Terra. Além disso, o sistema possui ainda um potenciômetro para fazer o ajuste fino do acompanhamento do movimento do Sol. Maiores informações sobre a construção de heliostatos com aplicações em Astronomia podem ser obtidas em Mills (1985).

Devido ao tempo limitado de pesquisa, não foi possível aplicar o heliostato nas escolas, apenas desenvolver um protótipo. Ainda assim, espera-se que este protótipo sirva de inspiração para a construção de outros heliostatos que venham a ser usado nas escolas do país. 


\section{APÊNDICE C - Questionários para o ensino funda-}

\section{mental}

\section{Questionário Inicial}

Curso: Observando o Sol

1. O Sol gera sua própria energia? Como?

2. O Sol é uma estrela? Como que você acha que é a superfície do Sol?

3. Que tamanho tem o Sol comparado com a Terra?

4. O Sol emite apenas luz visível?

5. Da onde vem a luz que ilumina o dia? E as cores do arco-íris?

6. O Sol pode afetar seu sinal de TV à cabo ? E seu sinal de rádio? E os astronautas, na estação espacial são afetados?

7. Desenhe o que você espera observar no Sol. 


\section{Questionário Final}

\section{Curso: Observando o Sol}

1. Como que o Sol produz energia?

2. Qual a estrela mais próxima da Terra?

3. Qual o tamanho do Sol comparado com a Terra?

4. O que o Sol emite além de luz?

5. Como fizemos para observar o espectro do Sol?

6. Como o Sol pode afetar a Terra?

7. Do que é composto um telescópio? Todos têm espelhos?

8. Como sabemos o que existe dentro do Sol?

9. O que você observou no disco do Sol? 


\section{APÊNDICE D - Questionários para o ensino médio}

\section{Questionário Inicial}

Curso: Física Solar

1. O Sol produz sua própria energia? Como?

2. O Sol é composto por o que? O que irá acontecer com o Sol daqui a 5 bilhões de anos?

3. Como que você acha que é a superfície do Sol?

4. O que são manchas solares?

5. O Sol está mais perto da Terra do que a Lua? A que distância você estima que o Sol está da Terra?

6. O Sol emite somente luz visível? O que mais o Sol emite?

7. Que cuidados precisamos ter ao observar o Sol com um telescópio?

8. Há elementos químicos no Sol? Quais? Como sabemos isso se nunca fomos até lá?

9. O que você espera observar no Sol?

10. O que você espera observar no espectro do Sol? 


\section{Questionário Final}

\section{Curso: Física Solar}

1. Qual processo está envolvido na produção de energia solar? O que precisamos para que este processo ocorra?

2. O Sol é composto por o que? E no fim de sua vida qual será seu aspecto e composição?

3. Como é a superfície do Sol?

4. O que são manchas solares? Como se originam?

5. Sol emite somente luz visível? O que mais o Sol emite?

6. Que cuidados precisamos ter ao observar o Sol com um telescópio? Quais os dois métodos de observação solar? Descreva-os.

7. Há elementos químicos no Sol? Quais? Como sabemos isso se nunca fomos até lá?

8. O que você observou no Sol com o filtro hidrogênio alfa e sem?

9. O que você observou no espectro do Sol? De que materiais precisou para observar o espectro solar?

10. O que são as linhas brilhantes no espectro das lâmpadas? E as linhas escuras no Sol? Por que as linhas são escuras no espectro solar e brilhantes no espectro das lâmpadas? 


\section{APÊNDICE E - Questionário de opinião sobre os cur-}

SOS

1. O que vocês acharam do curso?

2. O que poderia ser melhorado?

3. O que aprenderam sobre o Sol?

4. O que gostaram mais no curso? 